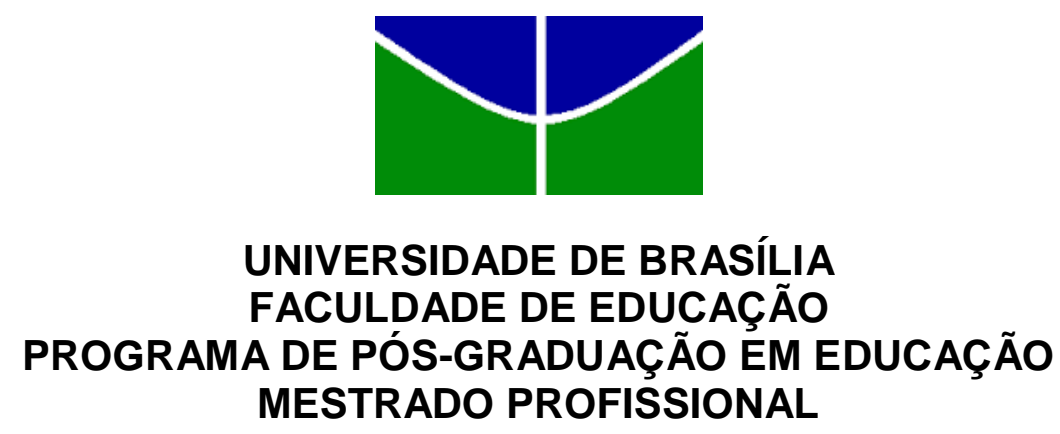

UNIVERSIDADE DE BRASÍLIA

FACULDADE DE EDUCACÃO

MESTRADO PROFISSIONAL

O PAPEL DO TÉCNICO EM AGROPECUÁRIA: ENTRE O

LÉXICO ESPECIALIZADO E O LÉXICO COMUM

MARIA BETÂNIA RODRIGUES DE MENEZES

BRASÍLIA-DF

2016 
MARIA BETÂNIA RODRIGUES DE MENEZES

\title{
O PAPEL DO TÉCNICO EM AGROPECUÁRIA: ENTRE O LÉXICO ESPECIALIZADO E O LÉXICO COMUM
}

\author{
Dissertação apresentada ao Programa de Pós- \\ Graduação em Educação Profissional da Faculdade \\ de Educação da Universidade de Brasília, como \\ parte dos requisitos para obtenção do título de \\ Mestre em Educação na área de Políticas Públicas \\ e Gestão da Educação Profissional e Tecnológica. \\ Orientador: Prof. Dr. Remi Castioni \\ Coorientadora: Profa.Dra. Cleide Lemes Silva Cruz
}


Ficha catalográfica elaborada automaticamente, com os dados fornecidos pelo(a) autor(a)

Menezes, Maria Betânia Rodrigues de

O papel do técnico em Agropecuária: entre

léxico especializado e o léxico comum / Maria Betânia

Rodrigues de Menezes; orientador Remi Castioni; co

orientador Cleide Lemes da Silva Cruz. -- Brasília, 2016 .

$148 \mathrm{p}$.

Dissertação (Mestrado - Mestrado Profissional em Educação) -- Universidade de Brasília, 2016.

1. Variação terminológica. 2. Socioterminologia. 3 Terminologia. 4. Glossário Terminológico. 5.

Agropecuária. I. Castioni, Remi, orient. II. Cruz, Cleide Lemes da Silva, co-orient. III. Título. 


\section{UNIVERSIDADE DE BRASÍLIA \\ FACULDADE DE EDUCAÇÃOO \\ PROGRAMA DE PÓS-GRADUAÇÃO EM EDUCAÇÃO MESTRADO PROFISSIONAL}

\section{MARIA BETÂNIA RODRIGUES DE MENEZES}

O PAPEL DO TÉCNICO EM AGROPECUÁRIA: ENTRE O LÉXICO ESPECIALIZADO E O LÉXICO COMUM

Dissertaçâo apresentada ao Programa de Pós-Graduação em Eduicaçâo Profissional da Faculdade de Educaçăo da Universidade de Brasilia, como parte dos requisitos para obtençåo do titulo de Mestre em Educaçăo

Orientadon: Prof. Dr. Remi Castioni

Coonientadora: Prola. Dra. Cletde Lemes da Siva Cruz

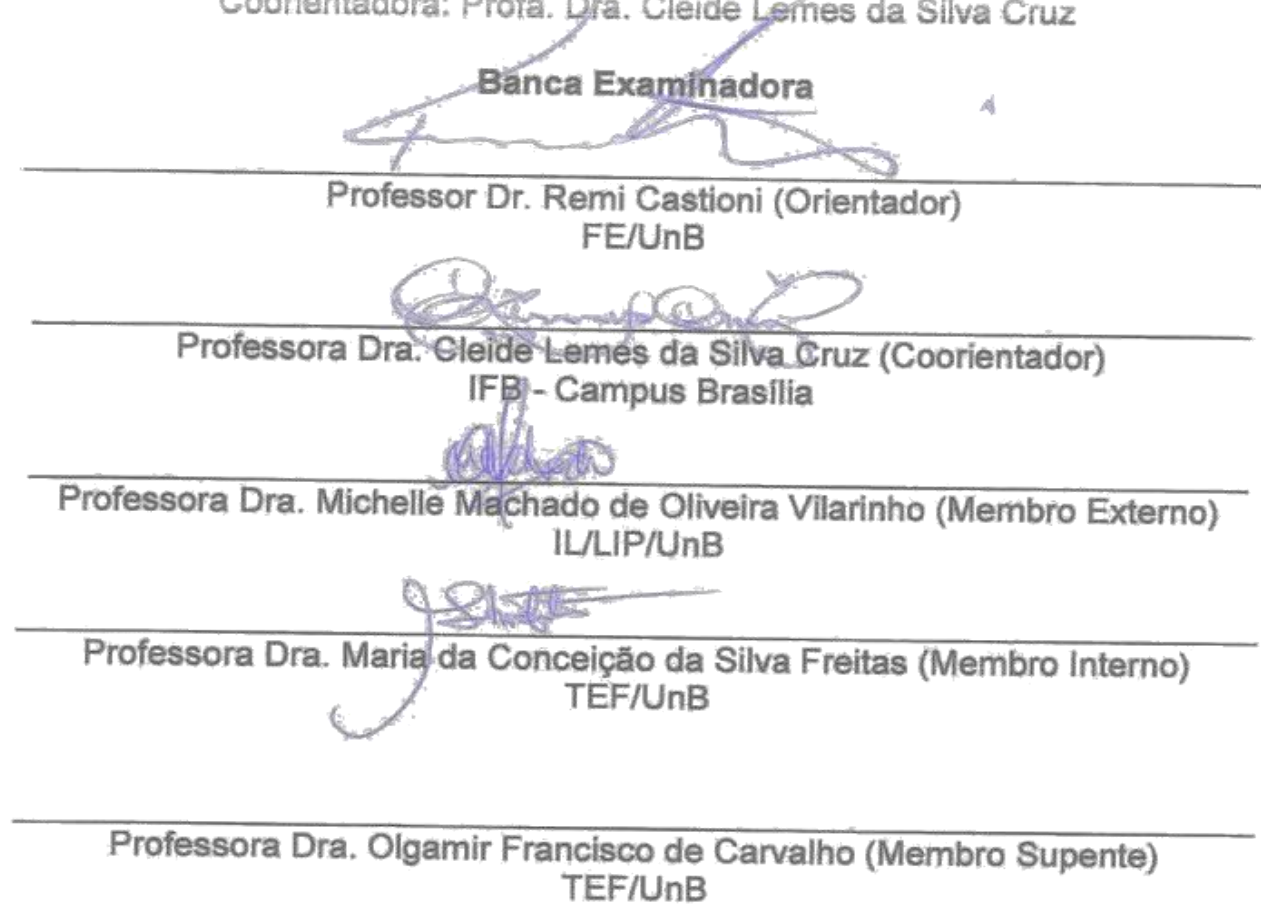

Aprovado em 13 los fonile 
Dedico este trabalho aos meus pais, Biu Rodrigues e Socorro Araújo. 


\section{AGRADECIMENTOS}

A princípio, agradeço a Deus por ser o grande norteador da minha vida, fonte de refúgio e meu baluarte.

Ao meu orientador, Remi Castioni, pela seriedade de seu trabalho e a sua grande capacidade de transmitir conhecimento com tenuidade $\mathrm{e}$ compromisso.

À minha coorientadora, Cleide Lemes da Silva Cruz, pela competência em sua colaboração desta dissertação, pelos livros a mim disponibilizados, e por ter me inspirado na produção deste trabalho aqui apresentado.

A todos os professores do Programa de Pós-graduação em EducaçãoPPGE pela total dedicação, organização e compromisso nas aulas ministradas.

Ao meu pai, Biu Rodrigues pelas orações nas horas de dificuldades e pelo companheirismo, quando eu chegava cansada da universidade.

À minha mãe Socorro Araújo, professora de História e Geografia, a qual foi o meu espelho de perseverança e força, que sempre me acompanhou na trajetória escolar e enriqueceu nossa casa com uma biblioteca, onde eu e minha irmã nos deleitávamos em meio a muitas enciclopédias.

À minha irmã Paula Valéria por cuidar dos nossos pais idosos, sem medir esforços no período deste trabalho.

À minha companheira, Hellen Amaral pela colaboração e incentivo, desde a trajetória do curso das disciplinas, qualificação, pesquisa e defesa.

Aos meus alunos colaboradores do curso Técnico Integrado ao Ensino Médio em Agropecuária do IFTO Campus - Araguatins, em especial a Júlia Cláudia, Taís Gouveia, Roberto Braga e Railton Santos. 


\section{RESUMO}

O tema central desta pesquisa é o estudo da Variação em Terminologia na área da Agropecuária, com o objetivo de investigar o papel do técnico: entre o léxico especializado e o léxico comum do Curso Técnico Integrado ao Ensino Médio, do Instituto Federal de Educação, Ciência e Tecnologia do Tocantins IFTO - Campus Araguatins, à luz da Socioterminologia e do modelo da Teoria da Variação proposto por Faulstish (1995-2003), esta teoria se adéqua à presente pesquisa por priorizar o estudo do termo e do conceito, e observar diretamente o uso da língua e seu registro. $O$ que se pretende com este estudo é constatar que existe variação na língua de especialidade (LESP) e responder em que medida a constatação da variação contribuirá para a transmissão do conhecimento técnico pelos alunos aos agropecuaristas da microrregião do Bico do Papagaio. A pesquisa é qualitativa, de caráter documental, de levantamento bibliográfico e de campo. Analisaram-se dados da agropecuária, coletados em referenciais bibliográfico, utilizados por professores da área técnica do curso; relatórios de estágios supervisionado dos alunos e aplicação de questionários com perguntas abertas e fechadas aos agropecuaristas, com base análise de dados, se evidenciaram a ocorrência de variantes concorrentes e coocorrentes de acordo com 0 constructo proposto por Faulstich (1998). Como resultado apresenta-se um Glossário de Terminologias da Agropecuária, divididos em cinco subáreas que é composto de cerca de 280 termos, sendo 71 da área da apicultura, 43 da avicultura, 46 da bovinocultura, 34 da horticultura e 57 da suinocultura. Ele servirá de consulta aos alunos e professores para contribuir com a qualificação do profissional, o que atende demandas ao exercício da profissão. O glossário apresenta uma pequena parcela dos termos coletados junto aos agropecuaristas e poderá ser atualizado, no futuro.

Palavras-Chave: agropecuária, variação terminológica, Socioterminologia, constructo de Faulstich, o papel do técnico do IFTO, Campus - Araguatins. 


\section{ABSTRACT}

The central theme of this research is the study of variation in terminology in the area of Agriculture, with the objective of investigate the role of technician: between the specialized lexicon and the common lexicon of Technical Course Integrated With High School, of Instituto Federal de Educação, Ciência e Tecnologia do Tocantins IFTO - Campus Araguatins through the Socioterminology and the model of Theory of Variation proposed by Faustish (1995-2013), this theory fits in the present research by prioritizing the study of the term and of the concept, and observe directly the use of the language and its register. The aim of this study is find that exist variation in the language of specialty (língua de especialidade - LESP) and respond to what extend the finding of variation will contribute to the transmission of technical knowledge from students to the ranchers of the microregion of the Bico do Papagaio. The research is qualitative, with documentary character, with literature review and field survey. Data of Agriculture were analyzed, collected in bibliographical references, used by teachers of technical area of the course; reports of supervised internships of students and questionnaires with open and closed questions for ranchers, based on data analysis, they were revealed the occurence of concurrent variants and variants that ocurring together. As a result a Glossary of Terminology of Agriculture is presented, divided into five sub-areas comprise from about 280 terms, being 71 from area of apicultura, 43 from avicultura, 46 from bovinocultura, 34 from horticultura and 57 from suinocultura. It will serve for query of students and teachers to contribute with the qualification of professional, which meets demands on the profession. Glossary presents a small portion of the terms collected with the ranchers and may be use in the future.

Key-Words: agriculture, terminological variation, Socioterminology, Faulstich's constructo, the role of technician of IFTO, Campus - Araguatins. 


\section{LISTA DE QUADROS}

Quadro 1 - As Microrregiões do Tocantins e a localização dos Campi.

Quadro 2 - Ramos das Atividades das Empresas Concedentes de Estágio para o Curso de Agropecuária

Quadro 3 - Empregabilidade dos Egressos do Campus Araguatins.

Quadro 4 - Egresso em Atuação de Empregabilidade nas áreas de Agropecuária.

\section{TABELAS}

Tabela 1 - Número de Assentamentos, área total e famílias assentadas por municípios na Região do Bico do Papagaio.

\section{FIGURAS}

Figura 1 - Constructo teórico da variação em terminologia

Figura 2 - Modelo reduzido das Variantes concorrentes 


\title{
LISTA DE ABREVIATURAS E SIGLAS
}

\author{
APL - Arranjos Produtivos Locais \\ CAR - Cadastro Ambiental Rural \\ CEFET - Centros Federais de Educação Tecnológica \\ CNE - Conselho Nacional de Educação \\ DCN - Diretrizes Curriculares Nacionais \\ CEB - Câmara de Educação Básica \\ EAFA - Escola Agrotécnica Federal de Araguatins \\ EB - Ensino Básico \\ EP - Ensino Profissional \\ EPI - Equipamento de Proteção Individual \\ ET - Escolas Técnicas Federais \\ ETC - Escola Técnica Federal de Palmas \\ IBGE - Instituto Brasileiro de geografia e Estatística \\ IFTO - Instituto Federal de Educação, Ciência e Tecnologia do Tocantins \\ IF - Instituto Federal de Educação, Ciência e Tecnologia \\ INCRA - Instituto Nacional de Colonização e Reforma Agrária \\ LDB - Lei de Diretrizes e Bases \\ MEC - Ministério da Educação \\ PA - Projetos de Assentamentos \\ PDE - Plano Nacional de Educação \\ PIB - Produto Interno Bruto \\ PPC - Projeto pedagógico de Curso \\ PRONAF - Programa Nacional de Agricultura familiar \\ PRONAMP - Programa Nacional de Apoio ao Médio Produtor \\ PROEJA - Programa de Educação Profissional para Jovens e Adultos \\ PNE - Plano Nacional de Educação \\ PUC - Pontifícia Universidade Católica de São Paulo \\ PRONATEC - Programa Nacional de Acesso ao Ensino Técnico e Emprego \\ TCT - Teoria Comunicativa da Terminologia \\ TGT - Teoria Geral da Terminologia \\ UEP - Unidades Produtivas de Educação \\ UFT - Universidade Federal do Tocantins \\ UNB - Universidade de Brasília
}




\section{SUMÁRIO}

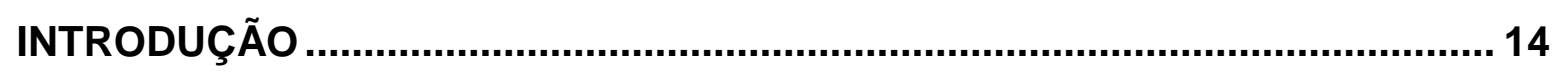

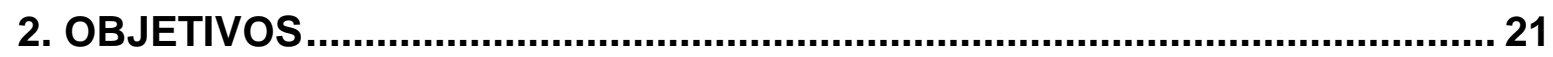

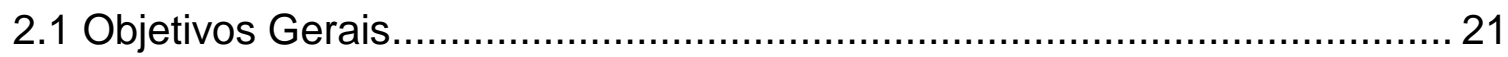

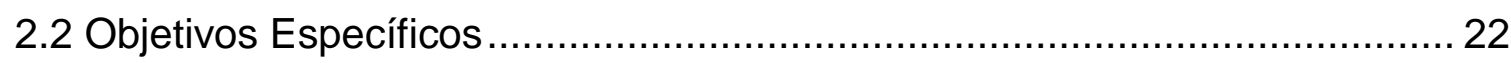

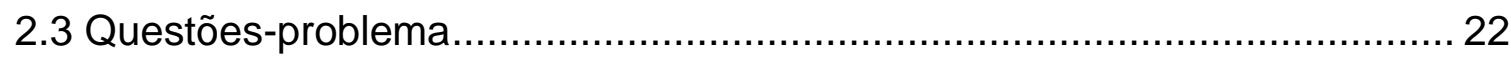

3. POLÍTICAS PÚBLICAS DA EDUCAÇÂO PROFISSIONAL NO BRASIL........ 24

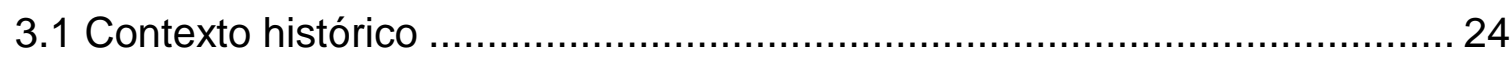

3.2 A Educação Profissional e o Regime Militar ............................................. 26

3.3 A Constituição Federal de 1988 e o Debate Pedagógico sobre a

Educação Politécnica ...................................................................................... 29

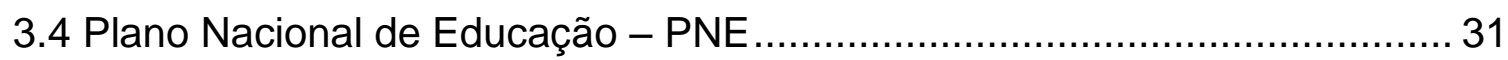

3.5 Criação das Diretrizes Curriculares Nacionais para a Educação

Profissional Técnica de Nível Médio ................................................................ 33

3.6 A Rede Federal de Educação Profissional.................................................. 35

3.7 O Instituto Federal de Educação, Ciência e Tecnologia do Tocantins .......... 37

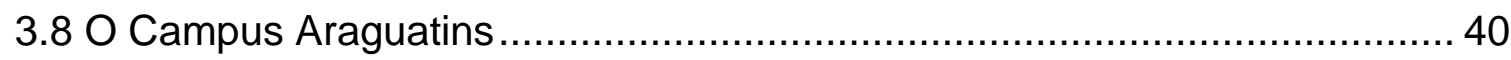

3.9 O Curso Técnico em Agropecuária ............................................................. 41

4. A INVESTIGAÇÂO E SEU SUPORTE TEÓRICO: CONSTRUCTO DE FAULSTICH, A TEORIA DA SOCIOTERMINOLOGIA E A VARIAÇÂO EM

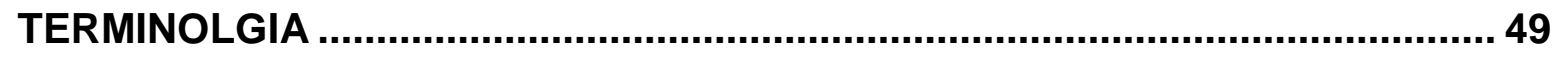

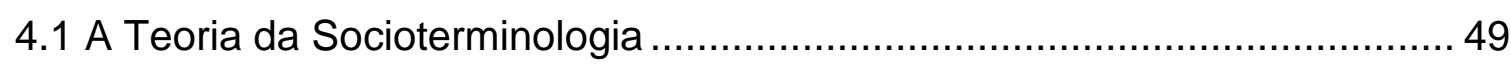

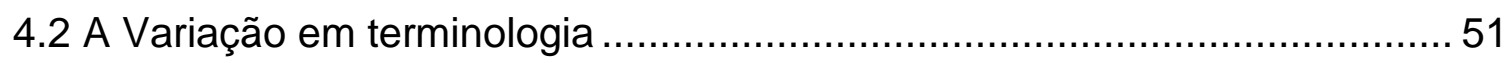

4.3 O Constructo da Teoria da Variação de Faulstich........................................55

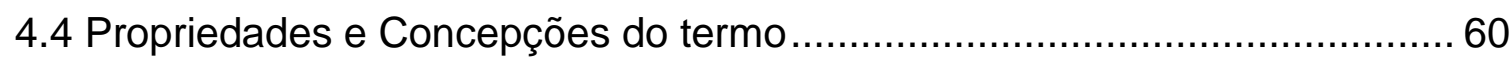

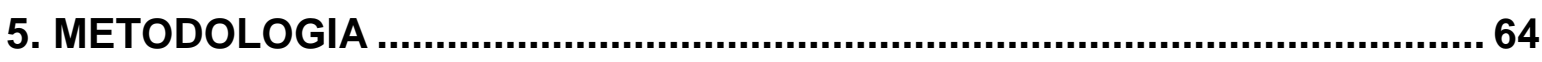

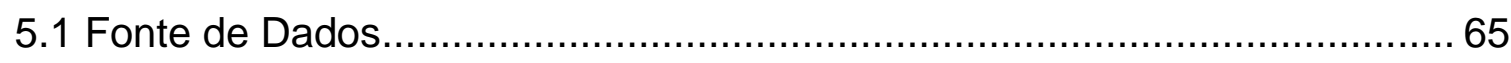

5.2 Critérios para recolha e organização dos dados ....................................... 70 


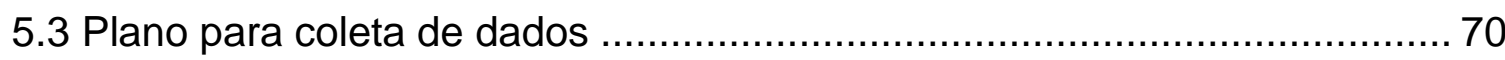

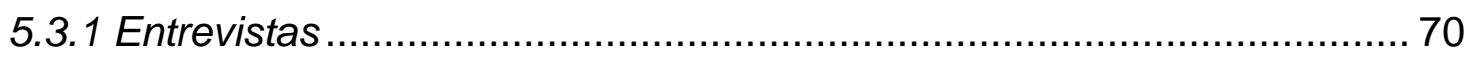

5.4 Seleção e organização dos dados: ......................................................... 71

6. ANÁLISE E DISCUSSÃO DOS DADOS …….............................................. 74

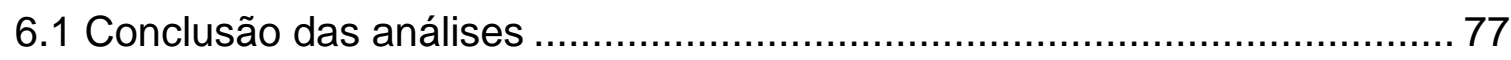

7. PRODUTO TÉCNICO - GLOSSÁRIO DE TERMINOLOGIAS DA

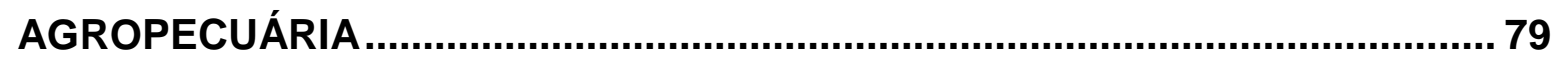

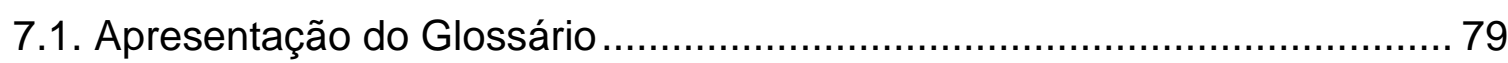

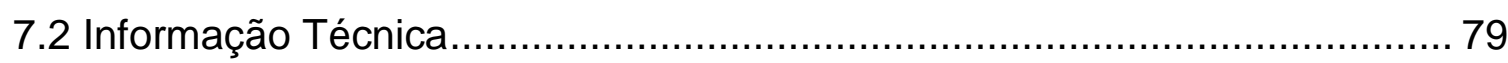

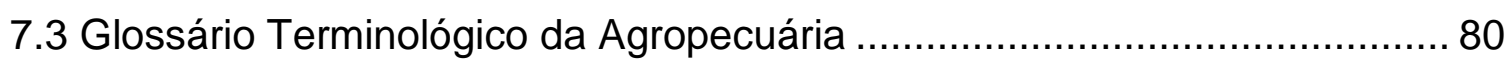

7.3.1 - GLOSSÁRIO DE TERMINOLOGIAS DA APICULTURA ...................... 80

7.3.2 - GLOSSÁRIO DE TERMINOLOGIAS DA AVICULTURA .................... 86

7.3.3 - GLOSSÁRIO DE TERMINOLOGIAS DA BOVINOCULTURA ..............91

7.3.4 - GLOSSÁRIO DE TERMINOLOGIAS DA HORTICULTURA .................97

7.3.5 - GLOSSÁRIO DE TERMINOLOGIAS DA SUINOCULTURA.............. 105

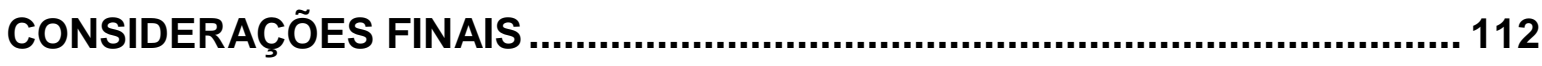

REFERENCIAIS BIBLIOGRÁFICOS......................................................... 115

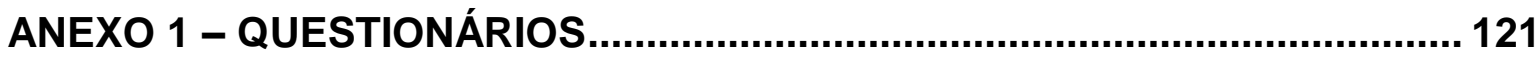

ANEXO 2 - LISTA DOS TERMOS VARIANTES.............................................. 141 


\section{INTRODUÇÃO}

O Tema dessa dissertação é o estudo da Variação em Terminologia, tendo como enfoque, o papel do técnico em agropecuária: entre o léxico especializado e o léxico comum. As subáreas selecionadas foram: apicultura, avicultura, bovinocultura, horticultura e suinocultura do curso Técnico em Agropecuária do IFTO - Campus Araguatins. Como suporte teórico serão utilizados os conceitos e teorias presentes na Socioterminologia (1995) e o modelo da Teoria da Variação proposto por Faulstich (1995-2003) no que se refere à classificação dos termos e também, explicaremos o comportamento nos textos especializados e nos contextos de uso. A presente pesquisa é de natureza qualitativa, na área da Educação juntamente com o Léxico e a Terminologia.

Em muitas áreas do conhecimento é frequente encontrarmos em qualquer sociedade, formas e termos específicos que estão distantes das mais comuns ou gerais. Quando falamos em terminologia nos referimos à língua de especialidade. Sabemos, portanto, que nem todas as circunstâncias da vida são tratadas de forma geral. Um especialista da área da Agropecuária, por exemplo, como um técnico ou um Engenheiro Agrônomo, usam termos específicos que não são usados por um leigo. Apresenta-se aqui, a importância da Terminologia como disciplina, que tem como objetivo, o estudo dos termos. Enquanto o léxico é geral o termo é específico.

Segundo Faustich (2001, p.11-40) há duas leituras hoje da terminologia, uma delas analisa o termo na ótica do prescritivo, e a outra se baseia nas teorias da variação linguística.

Para alguns, o termo é a denominação de uma noção unívoca; para outros, os termos são entidades variantes, porque fazem parte de situações comunicativas distintas e funcionam na diversidade da(s) língua(s). No contexto de variedades, a gramática que rege os termos não é outra senão aquela mesma que estrutura os lexemas. O que distingue termos de lexemas é a semântica pragmática, por meio da qual identificamos o movimento gramatical e conceitual do termo. 
Ainda para Faulstich (Id., Ibid., p.11-40) um modelo de análise possível é o que parte do funcionalismo, que proporciona a criação de categorias e de tipos de variantes terminológicas em consonância com os usos. Levando em consideração que, em terminologia geral, forma e conteúdo podem permanecer não-variáveis, ou seja, unívocos, designativos. Para a terminologia funcional é postulado que os termos encontram terreno para a variação. E é na terminologia funcional que nos basearemos para a sustentação da presente pesquisa.

Levamos em consideração que a língua sofre variações em seu uso real, baseado nas relações entre a estrutura, os aspectos sociais e culturais de produção linguística. A sociolinguística, como corrente teórica, entende a língua como instituição social e se encarrega de estudar todos esses fenômenos. Assim, tal como as outras unidades lexicais dos sistemas linguísticos, os termos também comportam variações das mais diferentes naturezas. Segundo essa constatação a autora (CABRÉ, 1993, p.119) certifica que:

os termos não formam parte de um sistema independente das palavras, mas que conformam com ela o léxico do falante, mas ao mesmo tempo, pelo fato de serem multidimensionais, podem ser analisados de outras perspectivas e, compartilham com outros signos de sistemas não linguísticos o espaço de comunicação especializada.

A sociolinguística estuda a língua em seu uso real, baseado nas relações entre a estrutura, os aspectos sociais e culturais da produção linguística. Esta corrente entende a língua como instituição social. Acerca desse assunto, Bakhtin (1999) afirma que a verdadeira essência da língua está voltada não para os sistemas abstratos de formas linguísticas, mas aos fenômenos sociais de interação verbal, através da enunciação. As crenças, os valores, o processo de construção de identidade em contextos institucionais variados é o escopo do estudo da língua.

Para Jakobson (1969), a língua compõe-se de subcódigos que são escolhidos pelo falante, de acordo com a função da mensagem, do interlocutor, e da relação existente entre os falantes dentro de um contexto, os quais são deferidos por ele como "fatores constitutivos de todo ato de comunicação verbal": o remetente, a mensagem, o destinatário, o contexto, o canal e o 
código. $\mathrm{O}$ ato comunicativo verbal é composto por esses elementos essenciais que interligados tornam a comunicação eficaz.

Marcuschi (2001, p. 187-217) afirma que nos meados dos anos 60, surge uma perspectiva nova para o ensino da língua. Assim marca-se oficialmente o lançamento da Sociolinguística sendo ela variacionista ou culturalista. A partir daí, origina uma concepção mais sistemática de considerar a língua como fato social e comprometido com a realidade sócio antropológica. Segundo ele, a ideia pessoal de noção de competência comunicativa definida por Dell Hymes "é um conjunto de competências dos falantes no seu desempenho linguístico contextualizado. Já a competência chomskyana não tinha sequer a participação de falantes humanos e era uma simples função interna e de domínio ideal de uma suposta língua" (MARCUSCHI, 2001, p. 187217). Ainda, para o autor, foi com base nas novas conquistas teóricas que 0 trabalho com a língua passa a

encarar, debater e combater todo o tipo de preconceito linguístico dando lugar as tentativas de valorização às variedades da língua não- padrão ou não-cultas. A escola passa a operar com a variedade e com a questão da diferença como um fato normal da língua, já que as línguas não são monolíticas nem homogêneas (MARCUSCHI, 2001, p. 187217).

Assim sendo, a língua tem uma relação direta com a sociedade, portanto possui em sua estrutura elementos culturais e históricos, que devem ser analisados e considerados, e a terminologia como parte dessa estrutura também é passível de variações.

Para Ciaspúscio (1998, p. 43), o termo "é uma unidade linguísticocomunicativa, resultado de determinada conceptualização por parte de um falante, e simultaneamente oferta de interpretação para os seus eventuais destinatários".

Existe uma diversidade de posicionamento em relação à concepção do termo, que vai muito além da contradição dos pesquisadores em compreender que o termo é uma unidade de conhecimento ou uma unidade pragmáticalinguística. Para Cabré (1999) a explicação sobre o termo possui uma 
dimensão multifacetada, caracterizando o que a TCT chama de poliedricidade do termo.

\begin{abstract}
Assim, o termo compreende tanto uma vertente conceitual, expressando conhecimento e fundamentos dos saberes, quanto uma vertente linguística, determinando sua naturalidade e integração aos sistemas linguísticos, além dos aspectos sociais que se agregam a uma de suas funcionalidades básicas: a de favorecer a transferência do conhecimento. Em síntese o termo é reflexo direto dos ângulos construtivos da Terminologia (KRIEGER, 2001, p.72).
\end{abstract}

Por sua vez, a terminologia, segundo Krieger e Finatto (2004, p. 16), é um "elemento inerente às chamadas comunicações especializadas, as quais são tradicionalmente associadas à redação de manuais, artigos, práticas científicas e textos especializados".

Nesse sentido, o léxico temático configura-se, portanto, "como um componente linguístico, não apenas inerente, mas também a serviço de comunicações especializadas, posto que os termos transmitem conteúdos próprios de cada área" (Id., Ibid., p. 17).

Nessa mesma perspectiva, continuam Krieger e Finatto (2004, p. 16), o emprego das terminologias assume determinadas funcionalidades nas comunicações profissionais, sendo necessário analisar o léxico de natureza técnico-científica, chamado também de léxico temático ou especializado (2001, p. 22), os quais cumprem duas dimensões essenciais: a de representação e de transmissão dos conhecimentos especializados em todos os campos do saber, científico e tecnológico segundo Krieger (2001, p. 23).

Todos os conceitos aliados ao uso da terminologia pela área especializada contribuem para a análise que propomos que é a de fazer a descrição socioterminológica ${ }^{1}$ do domínio da Agropecuária, e que leva em consideração a perspectiva variacionista da linguagem especializada, com 0 propósito de atingir os diferentes meios socioprofissionais que essa atividade envolve.

\footnotetext{
${ }^{1}$ Socioterminologia Termo usado pela primeira vez, em um artigo de 1981, escrito por JeanClaude Boulanger, conforme Faulstich (1995).
} 
Estudaremos a Agropecuária, nome que é dado ao estudo, teórico e prático da agricultura e da pecuária, em uma relação de reciprocidade. É uma atividade exercida, principalmente, por pequenos produtores, que unem as técnicas da agricultura - cultivo de plantas e hortaliças - com a pecuária, que é criação de animais (gado, suínos, aves entre outros).

As técnicas ligadas a essa área são apreendidas no Instituto Federal de Educação, Ciência e Tecnologia do Tocantins, Campus - Araguatins, local onde é ofertado tanto o Ensino Médio Integrado ao Curso Técnico em Agropecuária quanto o Curso Técnico na mesma área.

A escolha da Agropecuária como área técnica justifica-se pelo fato de esta atividade estar em plena expansão em todo o mundo, sobretudo no Brasil e, também, pelo acesso à terminologia da área por meio dos conteúdos trabalhados nas turmas do curso Técnico em Agropecuária, bem como o acesso aos agropecuaristas que habitam a mesorregião do Bico do Papagaio, onde foi realizada a coleta dos termos. A região na qual a pesquisa foi aplicada é predominantemente agropecuária e está situada no norte do país, possui vários Projetos de Assentamentos (PA's) financiados pelo INCRA, e a economia está voltada à agricultura familiar. Portanto, há um rico cenário a ser estudado, com diversas formas de analisar e compreender o fenômeno linguístico.

Chamou-nos a atenção a linguagem utilizada pelos assentados e a linguagem abordada nas aulas da área técnica, bem como na disciplina de Língua Portuguesa. Entendemos que as tarefas de análises linguísticas não devem ficar apenas no âmbito da palavra, do sintagma ou da oração, devem ser exploradas segundo o uso efetivo da língua no meio social, o que nos leva ao estudo da variação terminológica. Nessa pesquisa propomos analisar o uso de linguagem especializada nas perspectivas do ambiente escolar, de visitas técnicas, de assentados ou agropecuaristas. Além das perspectivas apresentadas anteriormente, analisaremos também a ocorrência e a frequência das variantes e verificaremos se se trata de variação instável ou estável.

Krieger (2001, p. 47) explica que também é importante considerar o funcionamento da linguagem com toda a sua complexidade para descrever, em 
melhores condições, a especificidade dos contextos discursivos nos quais ela se manifesta em toda a sua diversidade de configurações. Em larga medida, portanto, o conhecimento e a compreensão de uma área de conhecimento vinculam-se ao domínio da linguagem desta mesma área. O núcleo específico de uma linguagem de especialidade é seu vocabulário, que "normalizado e organizado semântica e logicamente" constitui a terminologia da área, Cruz (2005, p. 28). A partir de então, vários são os linguistas que defendem o estudo e o registro social do termo, pois reconhecem que as terminologias estão abertas à variação.

Dessa forma, escolhemos a área da Agropecuária por acreditarmos que os termos veiculados nesse campo especializado poderão contribuir para a adequação da linguagem técnica pelos estudantes da Agropecuária do IFTO, tanto no momento das atividades desenvolvidas em sala de aula, quanto nas atividades práticas do campo, junto aos agropecuaristas da região. Esse estudo socioterminológico poderá contribuir para a indicação de quais tipos de variações ocorrem e como elas ocorrem, segundo o modelo de Faulstich (1998), possibilitando o estabelecimento da frequência de ocorrências de termos e em quais contextos. É relevante salientar que nossos propósitos estão embasados, principalmente, no caráter comunicativo que a Terminologia tem apresentado nos últimos anos, permitindo tratar os termos como distintas unidades transmissoras de conhecimento especializado.

A proposta desta pesquisa é a análise socioterminológica que investiga a variação dos termos da área da Agropecuária em situação de uso, tanto pelos técnicos da área quanto pelos agropecuaristas. Contamos com um corpus formado de termos da linguagem de especialidade da Agropecuária, na forma como são veiculados em manuais, artigos científicos, relatórios de pesquisa e relatórios técnicos - impressos e em formato eletrônico, referenciais bibliográficos utilizados pelos professores. Além disso, o corpus também é composto por questionários que foram aplicados nos PA's Boa Sorte, Natal, e aos produtores rurais na microrregião do Bico do Papagaio, os quais nasceram nessa localidade ou residiram na região aos cinco anos de idade. Nos questionários aplicados, foram extraídos os termos da linguagem oral. 
Ao final, procuramos responder em que medida a constatação da variação, contribuirá para a transmissão do conhecimento técnico, entre alunos do curso e agropecuaristas. Temos a intenção de contribuir para 0 desenvolvimento de habilidades e competências propostas pelo PPC (Projeto Pedagógico de Curso) da Instituição de Ensino, como habilitar e qualificar o profissional, atendendo às atribuições inerentes ao exercício da profissão do Técnico Agrícola. Como produto, construímos um Glossário que tem como objetivo facilitar o entendimento dos principais termos técnicos da Agropecuária e das subáreas investigadas.

Diante do exposto, esta dissertação está organizada de modo que no capítulo I, apresentamos os objetivos da pesquisa gerais e específicos, juntamente com as questões-problema destacando o estudo da variação terminológica na área da Agropecuária que seja capaz de investigar questões relativas ao ensino da língua, de modo a trabalhar a linguagem de especialidade como método de estudo das mudanças sociais e culturais. $O$ foco do estudo são as variações em terminologia da área da Agropecuária, segundo o modelo de Faulstich (1993-2003) e da Socioterminologia (1995). Temos em vista "o desenvolvimento de contribuição técnica na área da educação, voltada ao desenvolvimento local e com característica de inovação social"(Resolução oo 01 da Coordenação do Programa de Mestrado Profissional em Educação, 2013).

No Capítulo II, discutimos uma breve abordagem histórica sobre as Políticas Públicas da Educação Profissional no Brasil, fazendo um recorte na história, desde a educação propedêutica até a expansão dos Institutos Federais de Educação. Ressaltamos o Histórico do Instituto Federal do Tocantins, desde a fundação da Escola Agrotécnica Federal de Araguatins (EAFA), através do decreto № 91.673 em 20 de setembro de 1985, até a Lei no 11.892 que transformou as Escolas Agrotécnicas Federais em Institutos Federais de Educação, Ciência e tecnologia, destacando o Campus Araguatins e o Curso Técnico em Agropecuária.

No Capítulo III, com base no referencial teórico discutimos os pressupostos teóricos da Terminologia, uma análise do termo à luz da 
prescrição elaborada por Eugen Wüister e na visão das teorias da variação linguística; os aspectos conceituais da socioterminologia; o constructo da teoria da variação proposto por Faulstich $(1995-2003)$ e as propriedades e concepções do termo.

No Capítulo IV, apresentamos a metodologia utilizada para recolha de dados, e as características do corpus. Uma descrição dos termos coletados em manuais, artigos científicos, relatórios de pesquisa e relatórios técnicos impressos e em formato eletrônico que foram submetidos à análise. Além de uma descrição da metodologia usada na elaboração dos questionários de pesquisa que foram aplicados nos PA's Boa Sorte e Natal, aos produtores rurais da microrregião analisada.

No Capítulo V, procedemos à análise de dados, com ênfase na variação terminológica proposta por Faulstich (1995-2003).

No Capítulo VI, apresentamos o produto técnico em forma de glossário em ordem alfabética e sistêmica, divididos em cinco subáreas que é composto de cerca de 280 termos, sendo 71 da área da apicultura, 43 da avicultura, 46 da bovinocultura, 34 da horticultura e 57 da suinocultura. Ele servirá de consulta aos alunos e professores para contribuir com a qualificação do profissional, o que atende demandas ao exercício da profissão.

Em seguida, passamos às considerações finais, seguidas das referências bibliográficas e dos anexos que apresentam dados complementares acerca dos termos analisados.

\section{OBJETIVOS}

\subsection{Objetivos Gerais}

O objetivo geral é o estudo da variação terminológica na área da Agropecuária ligadas às questões relativas ao ensino da língua, de modo a trabalhar a língua de especialidade como método de estudo do registro da linguagem técnica, das mudanças sociais e culturais, de modo a contribuir para a qualificação do profissional, atendendo às atribuições inerentes ao exercício da profissão, conforme as Políticas Públicas da Educação Profissional e Tecnológica. 
Para atingir esse objetivo, foram investigados os termos da área de Agropecuária e nas subáreas apicultura, avicultura, bovinocultura, suinocultura e horticultura, segundo o modelo da teoria da variação em terminologia proposta por Faulstich (1995-2003). Listamos, inicialmente, algumas subáreas da Agropecuária de modo a investigarmos qual das subáreas forneceria uma maior quantidade de termos para nossa investigação. $O$ foco da socioterminologia possibilita não só uma análise dos termos sob o ponto de vista da variação, mas também o estudo dos fatores de influência na sua categorização e função desses termos que vão além das características morfossintáticas e conceituais. Além disso, fornece importantes subsídios para explicar a produtividade e a variação entre termos da área nos textos.

\subsection{Objetivos Específicos}

Para atingir o objetivo geral, foram propostos os seguintes objetivos específicos:

$\checkmark$ identificar, primeiramente, as subáreas fornecem os termos da área da Agropecuária;

$\checkmark$ delimitar o corpus da pesquisa para investigação;

$\checkmark$ adotar critérios e reconhecimento de categorização para análise do tipo de variação apresentada pelos termos selecionados;

$\checkmark$ descrever a ocorrência de variação de cada termo com a intenção de explicar o modo como o usuário reconhece o termo e faz a variação de forma espontânea.

\subsection{Questões-problema}

Em resumo, buscaremos responder aos seguintes questionamentos:

$\checkmark$ quais aspectos permitem caracterizar a variação na linguagem de especialidade da Agropecuária?

$\checkmark$ em que medida estes aspectos permitem explicar sua formação e função em um texto especializado e em situação de uso? 
$\checkmark$ quais os possíveis motivos que dificultam a comunicação no repasse do conhecimento científico, feito pelos técnicos na hora da assistência aos pequenos produtores e assentados?

$\checkmark$ em que medida a constatação da variação contribuirá para a transmissão do conhecimento técnico pelos alunos do Curso Técnico em Agropecuária Integrado ao nível Médio do IFTO - Campus Araguatins? 


\section{POLÍTICAS PÚBLICAS DA EDUCAÇÂO PROFISSIONAL NO BRASIL}

\subsection{Contexto histórico}

O contexto histórico da educação profissional no Brasil teve início antes do século XIX, com a educação propedêutica, apresentada como cursos introdutórios, que visavam suprir as necessidades básicas de conhecimento em assuntos como artes, ciências e educação, contudo não capacitavam as pessoas profissionalmente e, o foco deste tipo de educação estava voltado às elites. Foi a partir de 1809 , que teve início o processo político da educação profissional no país, com da criação do Colégio das Fábricas, pelo príncipe regente, futuro D. João VI (Parecer n 16/99 - CEB/CNE)².

$\mathrm{Na}$ transição do século XIX para o XX surgiram as primeiras instituições de ensino privadas, que tinham objetivos assistencialistas e atendiam crianças pobres e órfãs, orientando-as na iniciação em ofícios como a tipografia, a carpintaria, a sapataria, a tornearia, entre outros. O objetivo era qualificar os filhos de trabalhadores para atuarem como operários nas indústrias que começaram a emergir em todo o país.

Em 1909, Nilo Peçanha fundou as Escolas de Aprendizes e Artífices e, em 1910, instalou dezenove delas no território brasileiro, com destino às classes menos favorecidas. No mesmo período, o ensino agrícola se organiza, tendo o objetivo de capacitar chefes "administradores e capatazes", apresentase aqui, uma educação de caráter elitista, e de reprodução da estrutura social predominante vigente.

Criou-se o Ministério de Educação e Saúde Pública, em 14 de novembro de 1930, hoje conhecida como Ministério da Educação (MEC), criado no governo do período provisório de Getúlio Vargas, tendo como primeiro ministro

\footnotetext{
${ }^{2}$ A primeira notícia de um esforço governamental em direção à profissionalização data de 1809, quando um Decreto do Príncipe Regente futuro D. João VI, criou o "Colégio das Fábricas", logo após a suspensão da proibição de funcionamento de indústrias manufatureiras em terras brasileiras. Posteriormente, em 1816, era proposta a criação de uma "Escola de Belas Artes", com o propósito de articular o ensino das ciências e do desenho para os ofícios mecânicos. Bem depois, em 1861, foi organizado, por Decreto Real, o "Instituto Comercial do Rio de Janeiro", cujos diplomados tinham preferência no preenchimento de cargos públicos das Secretarias de Estado. PARECER (CNE № 16/99 - CEB - Aprovado em 05.10.99).
} 
Francisco Gomes de Minas Gerais, que assumiu o cargo como compensação ao governo mineiro por ter participado da Revolução de 1930.

A principal medida tomada pelo ministro foi a assinatura de um decreto que criava universidades, ao invés de escolas superiores isoladas. Uniram-se para isso, três unidades de ensino superior. As Faculdades de Direito, Medicina e Engenharia ou podendo uma delas ser substituída, pela Faculdade de Educação, Ciências e Letras. Além de reformar o ensino secundário, o governo de Getúlio Vargas promovia a centralização das orientações e da estrutura de ensino, os cargos na área da educação eram sempre em seu governo, assumidos por mineiros, (FAVERO, 2006).

\begin{abstract}
A partir de 1930 inicia-se o esforço de arrumação e transformação do ensino superior no Brasil. O ajuntamento de três ou mais faculdades podia legalmente chamar-se universidade. É nesses termos que se fundam as Universidades de Minas Gerais - reorganizada em 1933 - e a Universidade de São Paulo, que em 1934, já expressa uma preocupação de superar o simples agrupamento de faculdades.
\end{abstract}

O ensino secundário existente na época não tinha uma base que pudesse formar um sistema nacional organizado, havia os sistemas estaduais, desarticulados com o sistema central, sendo eles sistemas de caráter acadêmico e intelectualista, com traços de imitação do sistema francês de ensino, seguido das grandes escolas de profissionais liberais, e eram na maioria públicas. Mas as vagas eram sempre preenchidas pela classe média, e a maioria da população ficava excluída. Algumas dessas vagas eram preenchidas por alunos que se dirigiam às escolas normais e técnicoprofissionais, e a partir do preenchimento dessas vagas por populares, o governo se sentia mais democrático, já que o ensino superior em quase sua totalidade, era destinado à elite brasileira.

O Ministério da Educação logo após o governo de Francisco Gomes foi assumido por Washiton Pires e Gustavo Capanema. O Ministro Capanema foi conhecido pelas reformas que promoveu. Neste período, a educação volta-se para a formação de massa de trabalhadores, especificamente para a preparação da força de trabalho e reprodução da acumulação. $O$ capitalismo propunha o antagonismo de classes. O sistema de produção atendia à 
racionalidade da divisão do trabalho exigida pelas práticas de gestão e organização Taylorista-fordista, iniciada no Brasil na década de 30 e tendo sua intensificação na década de 40. Busca-se resposta às necessidades do processo produtivo, começa a se firmar a dualidade estrutural histórica na educação. Para Kuenzer (2002, p. 27), "à elite correspondia a formação acadêmica intelectualizada, descolada de ações instrumentais, aos trabalhadores, a formação profissional".

Durante muitos anos as Escolas Técnicas eram pleiteadas pelos filhos de trabalhadores, sendo essa uma oportunidade única gratuita, que os operários viam para a ascensão profissional de seus filhos, isso se estendeu até 1970. Os estudantes eram descriminados pela sociedade por virem de classes desprestigiadas. "As escolas técnicas não habilitam para o ensino superior e sim preparam a mão de obra, criando condições para garantir a produtividade do setor industrial" (FREITAG, 2005, p. 94).

No ano de 1961 foi promulgada a Lei de Diretrizes e Bases da Educação Nacional (LDB), que determina o final dos exames que serviam de seleção, para o ingresso do colegial. A escola torna-se aberta e não obrigatória aos alunos que concluíam o $4^{\circ}$ ano primário. Nesse momento, setores vinculados a classes hegemônicas, reivindicavam a oferta da educação apenas para redes privadas. A burguesia como classe de domínio, centralizava a oferta da educação apenas para quem pudesse pagar retirando o direito ao acesso, à classe dos trabalhadores. Populistas e populares reivindicavam entre outros aspectos, o aumento de vagas gratuitas entre o colegial e o profissional, com a possibilidade de transferência de um para o outro (Id, 2000).

Às classes desfavorecidas começam a acordar e questionar seu direito ao acesso à educação gratuita, exigindo maior número de vagas que possibilitem a todos o ingresso e permanência na escola.

\subsection{A Educação Profissional e o Regime Militar}

A Educação profissional no país passa por uma fase ditatorial no decorrer do período em que os militares assumiram o poder político, o $2^{\circ} \mathrm{grau}$ profissionalizante passa a ser obrigatório. Começa uma expansão na rede de 
ensino para atender essa obrigatoriedade e com isso, cai a qualidade dos cursos. Já havia sido promulgada a primeira Lei de Diretrizes e Bases LDB e a educação profissional se enfraquece no país por diversos fatores, tais como a falta de professores qualificados para os cursos ofertados, materiais didáticos, e maquinarias.

O Regime Militar dura entre os anos de 1964 a 1985. Momentos cívicos passam a ser obrigatórios nas escolas, como o Hino Nacional e o hasteamento da bandeira, com intuito de formar estudantes passivos e obedientes, sem espaço para reflexão e questionamento do novo sistema político. A expansão dos Cursos Técnico-Profissionalizantes cresce devido ao "Milagre Brasileiro", denominada assim, a época em que houve um excepcional crescimento na economia entre o período de 1968 e 1973. Nesse período a taxa de crescimento do PIB saltou de 9,8\% em 1968 para 14\% em 1973, e a inflação passou de 25,5\% em 1968 para 15,6 em 1973, segundo Giambiagi et al (2005).

Paradoxalmente, aumentou-se a pobreza no país, e a renda se concentração nas mãos de poucas pessoas. Por conta do período de industrialização, a demanda de técnicos se elevava, e o incentivo ao Ensino Profissionalizante de Nível Médio aumenta. O período foi marcado pelo golpe militar que deixou obrigatório o $2^{\circ}$ grau profissionalizante.

Apesar da expansão na rede de ensino, a qualidade dos cursos diminui. As escolas públicas sofrem uma grande deterioração, pela falta de professores qualificados e a falta de equipamentos, o que compromete os cursos técnicos nas redes estaduais, com exceção das Escolas Técnicas e Agrotécnicas Federais por possuírem financiamento apropriado e corpo docente específico para os cursos.

A classe média tinha melhor situação econômica e se destinava às escolas da rede privada, com o objetivo de preparar-se para os cursos de nível superior. Há, portanto um dualismo entre Ensino Básico - EB e Ensino Profissional - EP, escola pública e privada, de modo que se cria o estereótipo de que a escola do setor privado é de qualidade e a escola do setor público não tem qualificação. 
As empresas privadas do setor educacional se fortaleciam. A educação segue a sociedade autoritária e desigual, onde o proletariado sofre com 0 desemprego, baixos salários e, estão submissos ao emprego nas fábricas. Essa política massacrou economicamente a classe trabalhadora operária brasileira.

O clima reinante no país se caracteriza, ao mesmo tempo, por uma combinação de medo da repressão do Estado e de euforia em decorrência do crescimento econômico. (GERMANO, 2005, p.159-160).

Dentro desse contexto histórico que se passava o país, os filhos dos trabalhadores estariam concentrados em sua formação profissional. O mais importante seria a oportunidade de emprego que esse tipo de formação poderia Ihes proporcionar. $O$ processo de ensino-aprendizagem para a cidadania através da educação estava descartado.

Por conta da falta de qualidade nos cursos técnicos nas redes estaduais de ensino, a oferta diminuiu, e no final dos anos 80 , em meio a nova LDB (Lei $n^{\circ}$ 9.394/96) já quase não mais havia o $2^{\circ}$ grau profissionalizante, com exceção nas Escolas Técnicas e Agrotécnicas Federais. Foi a partir daí, que Demerval Saviani retoma no debate pedagógico, no doutorado em educação da PUC-SP, o conceito de 'educação politécnica' que segundo o Dicionário da Educação Profissional em Saúde (2009) o termo pode ser considerado como sinônimos de concepção marxista de educação. Mesmo Karl Marx não tendo escrito um texto sistemático dedicado especificamente à questão pedagógica, ele se utilizava de contextos que criticava rigorosamente as relações sociais (MANACORDA, 1991). A ideia de Marx era de que a sociedade não permitisse que as crianças e os adolescentes fossem empregados, a menos que esse emprego produtivo fosse simultâneo à oferta da educação. Para ele a educação é entendida por três coisas:

1- educação intelectual

2- educação corporal, tal como a que se consegue com os exercícios de ginástica militares.

3- educação tecnológica, que recolhe os princípios gerais e de caráter científico de todo processo de produção e, ao mesmo tempo, inicia as 
crianças e os adolescentes no manejo de ferramentas elementares dos diversos ramos industriais.

O autor defende uma educação multilateral, apontando a finalidade de sua proposta de educação politécnica. Combinando o trabalho intelectual, exercícios corporais e trabalho produtivo.

\subsection{A Constituição Federal de 1988 e o Debate Pedagógico sobre a Educação Politécnica}

No país é promulgada a constituição de 1988 , sendo ela a base para a educação profissional, em seu capítulo III, Da Educação, Da Cultura e do Desporto, destaca-se:

o pleno desenvolvimento da pessoa, seu exercício da cidadania e qualificação para o trabalho, o ensino deverá ser ministrado em alguns princípios e, as universidades gozam de autonomia didático-científica, administrativa e de gestão financeira e patrimonial de acordo com os princípios do ensino, pesquisa e extensão (1988).

Com base no Art. 205 - A educação, direito de todos e dever do Estado e da família, será promovida e incentivada com a colaboração da sociedade, visando ao pleno desenvolvimento da pessoa, seu preparo para o exercício da cidadania e sua qualificação para o trabalho. No Art. 206 está exposto que 0 ensino será ministrado com base nos seguintes princípios:

I - igualdade de condições para o acesso e permanência na escola; II - liberdade de aprender, ensinar, pesquisar e divulgar o pensamento, a arte e o saber; III - pluralismo de ideias e de concepções pedagógicas e coexistência de instituições públicas e privadas de ensino; IV - gratuidade do ensino público em estabelecimentos oficiais; V- valorização dos profissionais do ensino, garantindo na forma da lei, planos de carreira para o magistério público, com piso salarial profissional e ingresso exclusivamente por concurso público, de provas e títulos, assegurado regime jurídico único para todas as instituições mantidas pela União; VI - gestão democrática do ensino público, na forma da lei e VII - garantia de padrão de qualidade.

Esse texto tornou-se primordial para a constituição da base legal à educação profissional. No mesmo ano, foi apresentado um espaço para discussão sobre leis complementares à LDB, abrindo-se portas para a questão da Educação Politécnica no País. 
No início do século, o termo "politecnia" se enquadrava como sinônimo de educação socialista. Para Saviani (1989, p.17), seria o "domínio dos fundamentos científicos das diferentes técnicas que caracterizam o processo de trabalho produtivo moderno". O teórico elabora um texto que defende a integração do Ensino Médio ao Ensino técnico, na perspectiva de desenvolver habilidades multilaterais dos indivíduos. Seria a utopia da educação, segundo ele, esse documento seria a "contribuição à elaboração da nova Lei de Diretrizes e Bases da Educação: um início de conversa". A partir desse texto, foi criado $\circ 1^{\circ}$ anteprojeto de LDB na perspectiva da politecnia, pelo deputado, Otávio Elísio.

Em 17 de abril de 1997, a Educação Profissional foi sistematizada pelo decreto de $n^{\circ} 2.208$, baixado pelo governo federal, onde regulamentava a LDB, e deixava paralela Educação Profissional e Educação Regular. Sendo a Educação Profissional dividida em três níveis. O Básico para jovens e adultos trabalhadores, que qualificava, mas não habilitava; o Técnico para jovens e adultos que tivessem terminado ou não o ensino médio; e o Tecnológico para jovens e adultos que tivessem terminado o ensino médio e ingressariam no superior.

O sonho da educação politécnica se enfraquece quando a EP se torna paralela e complementar à educação básica, pois a reforma dos anos 90 desautorizava o desenvolvimento do Ensino Técnico integrado ao Ensino Médio, dessa forma se evidencia o dualismo escolar de maneira mais formal. Cunha (2005) afirma que os cursos técnicos tiveram a partir disso, um currículo independente, tendo oferta tanto sequencial ou concomitante ao ensino médio, havendo uma separação entre a classe profissional e a acadêmica.

Nesse cenário, surge uma dissolução entre o pensar e o fazer, a inclusão à cultura de mercado é valorizada, e a reforma permite mais rapidez à educação profissional com o intuito de habilitar um maior número de cidadãos produtivos para inclusão no mercado. Esse padrão de educação se enquadra nos padrões neoliberais, em todo contexto hegemônico dessas políticas. A política da EP nesse momento é direcionada a uma classe, sobre isso, Frigotto e Ciavatta (2011, p. 624) afirmam que 
é na década de 1990, sob a base da mundialização do capital, das reformas que consubstanciam o desmanche do Estado na garantia de direitos coletivos e universais e do avassalador processo de privatizações, que a ideologia do capital humano se redefine, mediante as noções de sociedade do conhecimento, qualidade total, pedagogia das competências, empregabilidade e empreendedorismo. Trata-se de noções que hipertrofiam a dimensão individualista e da competição e induzem à formação aligeirada de jovens e adultos trabalhadores em cursos pragmáticos, tecnicistas e fragmentados ou a treinamentos breves de preparação para o trabalho simples, forma dominante a que somos condenados na divisão internacional do trabalho. $E$, de acordo com as necessidades do mercado, prepara-se uma minoria para o trabalho complexo.

Nos anos seguintes surge 0 decreto $n^{\circ} 5.154 / 04$ que revoga 0 decreto $n^{\circ}$ 2.208/97, deixando mais flexível o ensino profissionalizante, dando possibilidade de articulação entre o ensino médio e a educação profissional, com a oferta do ensino integral, ampliando os níveis de ensino em:

- nível Integrado, oferta o ensino médio e técnico em uma mesma matrícula;

- nível Concomitante, oferta o ensino médio e ensino técnico em matrículas distintas, porém ao mesmo tempo, podendo ser proposta em instituições diferentes;

- subsequente, destinadas a pessoas que já concluíram o ensino médio com a pretensão de ingressar no ensino superior.

Através da flexibilidade do ensino profissionalizante a partir de 2004, abriu-se um leque de possibilidade a muitas pessoas que desejavam qualificação e habilitação, ou até mesmo àquelas que desconheciam sua importância. Ter formação integral proporcionaria dignidade a muitos jovens e trabalhadores.

\subsection{Plano Nacional de Educação - PNE}

Junto à reforma das políticas da educação, foi criado o Plano Nacional de Educação (PNE). Na proporção que o quadro político brasileiro se desenhava, a educação começava a se impor como ferramenta essencial para o desenvolvimento do país. Havia uma grande preocupação com a instrução, considerando os seus vários níveis e modalidades. Despertou-se uma 
consciência sobre a importância da educação e, um amadurecimento desta concepção alastrou-se coletivamente, surgindo uma preocupação do governo, em elaborar um plano que sistematizasse a educação nacional.

Segundo Ciavatta (1990, p.328), o trabalho e o assistencialismo constituem-se "fundamentos de processos educativos associados à escola do trabalho sendo dois eixos fundamentais: a regeneração pelo trabalho e 0 trabalho para a modernização da população". O Ministério da Educação e Cultura propôs o primeiro Plano Nacional de Educação que surgiu em 1962. Já havia nesse período a LDB oㅜ 4.024, de 1961, e esse plano tinha aprovação do Conselho Federal de Educação, o mesmo não tinha sido proposto em forma de um projeto de lei. A base do plano consistia apenas em um conjunto de metas que deveriam ser lançadas em 8 anos, tanto quantitativamente, como qualitativamente.

Nos anos de 1965 e 1966, houve duas revisões desse plano, sendo introduzidas importantes alterações que ficaram conhecidas como Plano Complementar de Educação. Apresentava nova distribuição nos recursos federais. Após a Constituição Federal de 1988, ressurgiu a ideia de um plano com força de lei, que seria capaz de assegurar estabilidade às iniciativas governamentais na área da educação. $O$ art. 214 contempla essa obrigatoriedade. O deputado Ivan Valente apresenta o projeto de Lei $n^{\circ} 4.155$ que "aprova o Plano Nacional de Educação". O documento referência tem muita relevância porque apresenta contribuições para diminuir os problemas sociais, culturais, políticos e educacionais brasileiros.

Depois da aprovação do projeto de lei, o Congresso Nacional decreta que os Estados, o Distrito e os Municípios deveriam formular planos com duração de dez anos. O PNE no que contempla o nível e modalidades de Educação Tecnológica e Formação Profissional tem preocupação de diagnosticar e dar diretrizes, apresentando objetivos e metas. Segundo diagnóstico do PNE, a heterogeneidade e a diversidade da oferta da educação para o trabalho, eram elementos positivos, embora alguns fatores fossem preocupantes, como a quantidade insuficiente de oferta à população de jovens que precisavam ter competência para o mercado de trabalho, e aos adultos 
que precisavam ser reciclados, sendo que a oferta, por sua vez, favorecia pessoas de maior renda e melhor nível de escolaridade.

Para Moura (2010), este documento não teve elementos significativos no que diz respeito à integração do Ensino Médio e o Ensino Profissional com os princípios da Politecnia, que defende habilidades multilaterais dos indivíduos, existindo no documento, ambiguidade e hibridismo.

\subsection{Criação das Diretrizes Curriculares Nacionais para a Educação Profissional Técnica de Nível Médio}

Em 1996, no dia 20 de dezembro, é sancionada as Diretrizes e Bases da Educação Nacional (LDB), tendo em vista o mandato constitucional do inciso XXIV do art. 22 da Constituição Federal. Essa Lei conclama a Educação Profissional e Tecnológica entre os níveis e as modalidades de educação e ensino, e constitui a convergência de dois direitos fundamentais de todos os indivíduos: o direito à educação e o direito ao trabalho, sancionado no art. 227 da Constituição Federal como direito à profissionalização assegurada aos cidadãos.

O capítulo da LDB sobre a Educação Profissional foi inicialmente regulamentado pelo Decreto no 2.208/97. Na continuidade, a Câmara de Educação Básica (CEB) do Conselho Nacional de Educação (CNE), baseado no Parecer CNE/CEB no 16/99, estabelece as Diretrizes Curriculares Nacionais à Educação Profissional de Nível Técnico pela Resolução CNE/CEB № 4/99.

Segundo o Parecer (CNE/CEB n 11/2012), em 23 de julho de 2004, o Decreto no 2.208/97 foi substituído pelo Decreto ํo 5.154/2004, que possibilitava a volta da integração entre o Ensino Médio à Educação Profissional Técnica de Nível Médio, apresentando outras formas e oferta dessa modalidade de Educação Profissional e Tecnológica. Em decorrência, a Câmara de Educação Básica do CNE renova as Diretrizes Curriculares Nacionais para o Ensino Médio e as Diretrizes Curriculares Nacionais à Educação Profissional Técnica de Nível Médio, por meio da Resolução CNE/CEB no1/2005, com fundamento no Parecer CNE/CEB no 39/2004. Ainda se encontra registrado no relatório que: 
Posteriores a Resolução CNE/CEB nำ3/2008, que teve como base o Parecer CNE/CEB no 11/2008, dispôs sobre a instituição do Catálogo Nacional de Cursos Técnicos de Nível Médio, sendo que seu art. 3o determina que os cursos constantes desse Catálogo sejam organizados por eixos tecnológicos definidores de um projeto pedagógico que contemple as trajetórias dos itinerários formativos e estabeleça exigências profissionais que direcionem a ação educativa das instituições e dos sistemas de ensino na oferta da Educação Profissional Técnica de Nível Médio.

As Diretrizes Curriculares Nacionais (DCN) para a Educação Profissional Técnica de Nível Médio tem por princípio, através das alterações acrescentadas à LDB pela Lei ํㅜ 11.741/2008, dar suporte as instituições educacionais através de novas orientações, tendo como centro à Educação Profissional e Tecnológica de Nível Médio, também apresentando normas gerais para os cursos e programas destinados à formação da qualificação profissional, e para aos cursos e programas de especialização técnica de nível médio, com o intuito de fazer com que os trabalhadores se desenvolvam profissionalmente e tenham o aproveitamento de estudos realizados de acordo com as mudanças no mundo do trabalho.

Segundo Cordão (2013, p.26-47), o maior desafio encontrado na elaboração das DCN's foi o de compreender que a evolução tecnológica e as lutas sociais têm modificado profundamente as atuais relações no mundo do trabalho, já não se admite mais a formação de trabalhadores apenas para 0 desempenho de tarefas mecânicas.

A evolução tecnológica e as lutas sociais exigem dos novos profissionais capacidades multilaterais, devido à eletromecânica ser substituída pela base microeletrônica, exigindo do profissional, habilidades múltiplas, as quais são incluídas capacidades de análises e síntese. O mundo do trabalho moderno requer que o profissional tenha a atitude de julgar, avaliar situações-problemas e, criar situações inovadoras. Com isso, as instituições educacionais precisam atualizar-se no intuito de proporcionar condições ao profissional em exercer funções diversificadas com competência, (Id., Ibid., p. 26-47).

Essas significativas alterações exigem das instituições educacionais dedicadas à Educação Profissional e Tecnológica a formação de um novo profissional, já não basta mais o treinamento operacional para que 0 
trabalhador aprenda a fazer bem feito a tarefa que Ihe é atribuída. Ele deve adquirir condições para desenvolver competências profissionais que the ofereçam condições de intervir no próprio processo do fazer. O que se espera é que ele adquira condições efetivas de demonstrar que seu desenvolvimento profissional foi adequado, justamente quando os complexos sistemas de organização do trabalho e os sofisticados equipamentos tecnológicos apresentarem comportamento anormal, exigindo que o trabalhador demonstre suas reais condições de criar respostas apropriadas para solucioná-los em uma atuação qualificada.

As novas situações apresentadas requerem a demonstração de saberes inovadores no que se diz respeito ao conhecimento, permitindo que 0 trabalhador atue com originalidade e criatividade, conciliar a memorização, 0 automatismo, podem até colaborar para um bom desempenho em alguns exercícios profissionais, porém não é suficiente para o desenvolvimento pleno de um cidadão trabalhador.

\subsection{A Rede Federal de Educação Profissional}

A História da Educação Profissional no Brasil passou por vários momentos em destaque na Rede Federal, desde as 19 Escolas de Aprendizes Artífices. Como iniciação as Escolas Técnicas pelo presidente Nilo Peçanha em 1909, os Liceus Industriais em 1930, as Escolas Industriais e Técnicas em substituição aos Liceus em 1942, as Escolas Agrotécnicas, os CEFET's e a poderosa expansão dos Institutos Federais de Ensino em 2008, com 38 novos Institutos Federais de Educação, Ciência e Tecnologia (IFs), cuja responsabilidade é a educação básica, técnica e tecnológica, além de boa estrutura física e diversidades de cursos, ofertados de acordo com as necessidades regionais. Com essa expansão aumenta-se a chance de formação profissional a muitos filhos de trabalhadores para se qualificar e ingressar no mundo do trabalho. De acordo com a criação dos IF's (Lei no 11.892/08) a finalidade dos institutos é:

I - ofertar educação profissional e tecnológica, em todos os seus níveis e modalidades, formando e qualificando cidadãos com vistas na atuação 
profissional nos diversos setores da economia, com ênfase no desenvolvimento socioeconômico local, regional e nacional;

II - desenvolver a educação profissional e tecnológica como processo educativo e investigativo de geração e adaptação de soluções técnicas e tecnológicas às demandas sociais e peculiaridades regionais;

III - promover a integração e a verticalização da educação básica à educação profissional e educação superior, otimizando a infraestrutura física, os quadros de pessoal e os recursos de gestão;

IV - orientar sua oferta formativa em benefício da consolidação e fortalecimento dos arranjos produtivos, sociais e culturais locais, identificados com base no mapeamento das potencialidades de desenvolvimento socioeconômico e cultural no âmbito de atuação do Instituto Federal;

V - constituir-se em centro de excelência na oferta do ensino de ciências, em geral, e de ciências aplicadas, em particular, estimulando o desenvolvimento de espírito crítico, voltado à investigação empírica;

VI - qualificar-se como centro de referência no apoio à oferta do ensino de ciências nas instituições públicas de ensino, oferecendo capacitação técnica e atualização pedagógica aos docentes das redes públicas de ensino;

VII - desenvolver programas de extensão e de divulgação científica e tecnológica;

VIII - realizar e estimular a pesquisa aplicada, a produção cultural, o empreendedorismo, o cooperativismo e o desenvolvimento científico e tecnológico;

IX - promover a produção, o desenvolvimento e a transferência de tecnologias sociais, notadamente as voltadas à preservação do meio ambiente.

Os Institutos apresentam todas as modalidades e níveis de ensino com visão a qualificar os cidadãos em diversos setores da economia, local, regional e nacional. Oportunizando várias pessoas se qualificarem de acordo com níveis de escolaridade e suas necessidades. 
A Educação Profissional no país passou e ainda passa por grandes transformações, porém é notório que se caminha na busca do desenvolvimento do cidadão, visto que a educação tem o poder transformador de evoluir os indivíduos através do conhecimento, e é por intermédio dela que descobriremos um mundo mais justo, onde se respeite dignamente o direito às igualdades sociais.

\subsection{O Instituto Federal de Educação, Ciência e Tecnologia do Tocantins}

A criação do Instituto Federal de Educação, Ciência e Tecnologia do Tocantins se deu a partir da Lei no 11.892/08 dos Institutos Federais de educação. Trata-se de uma instituição fundada pela integração da Escola Técnica Federal de Palmas-ETC e a Escola Agrotécnica Federal de Araguatins-EAFA.

O IFTO, como todos os outros Institutos, integra o ensino, a pesquisa e extensão. Faz parte da história do ensino profissional no país e possui um corpo de profissionais especializados e concursados, dentro das referidas áreas de atuação. Tem a pretensão de formar profissionais que atendam as metas das novas tecnologias e desenvolvimento do país. As demandas da sociedade é um dos pontos que se destaca, através da atenção que é dada aos Arranjos Produtivos Locais, que são sempre vistos com prioridade. Com isso, proporciona desenvolvimento educacional, científico e tecnológico às regiões nas quais se localizam os campi e, consequentemente, contribui para o crescimento do Estado do Tocantins.

O Instituto é autônomo para criar e excluir curso desde que sejam na área de atuação territorial, e precisam ser autorizados por uma instância maior na instituição exemplo: Conselho Superior (Brasil, 2008). Os cursos criados existem a partir das necessidades regionais e locais e contemplam todas as modalidades de ensino, que são direcionados à Educação Profissional, Técnica de Nível Médio (Proeja, Subsequente, Integrado) Graduações (Licenciatura, Tecnologia e Bacharelado) e Cursos de Pós-Graduação.

O IFTO atende as Microrregiões do Estado. Para o Instituto Brasileiro de Geografia e Estatística (2010), o estado do Tocantins possui uma área 
territorial de $277.621,858 \mathrm{~km} 2$ e uma população estimada em 1.383.453 habitantes, distribuída em cento e trinta e nove municípios, após sua criação foi divido em Mesorregião e Microrregiões Geográficas, instituídas pela Resolução da Presidência do IBGE №. 11, de 5 de junho de 1990. O IBGE (1990, p.8) conceitua as Mesorregiões Geográficas como sendo

um conjunto de municípios ininterruptos, que fazem parte à mesma unidade da federação que apresentam formas de organização do espaço geográfico definidas pelas seguintes dimensões: o processo social, como determinante, o quadro natural, como condicionante, e a rede de comunicação e de lugares, como elemento de articulação espacial. Essas três dimensões possibilitam que o espaço delimitado como mesorregião tenha uma identidade regional. Esta identidade é uma realidade construída ao longo do tempo pela sociedade que aí se formou (IBGE, 1990, p. 8).

Já as Microrregiões Geográficas são definidas como um conjunto de municípios contínuos que são definidos como,

partes das mesorregiões que apresentam especificidades, quanto à organização do espaço. Essas especificidades não significam uniformidade de atributos, nem conferem às microrregiões autossuficiência e tampouco o caráter de serem únicas, devido a sua articulação a espaços maiores, quer à mesorregião, à Unidade da Federação, ou à totalidade nacional. Essas estruturas de produção diferenciadas podem resultar da presença de elementos do quadro natural ou de relações sociais e econômicas particulares (...). A organização do espaço microrregional foi identificada, também, pela vida de relações ao nível local, isto é, pela possibilidade de atender às populações, através do comércio de varejo ou atacado ou dos setores sociais básicos. Assim, a estrutura da produção para identificação das microrregiões é considerada em sentido totalizante, constituindo-se pela produção propriamente dita, distribuição, troca e consumo, incluindo atividades urbanas e rurais (IBGE, 1990, p. 8).

A Instituição de Ensino disponibiliza vários cursos que são ofertados nas Microrregiões do Tocantins, criados a partir das demandas locais e regionais, através dos Campi e dos Campi Avançados, abrangendo um total de 6 das 8 existentes. $\mathrm{O}$ crescente número de vagas que estão sendo criadas pelo IFTO e distribuídas nas Microrregiões do Estado possibilitam o alcance viável de cursos profissionalizantes a muitos filhos de trabalhadores, oportunizando seu ingresso no mundo produtivo. 
O quadro a seguir, apresenta a divisão por Campus que estão localizados em Microrregiões. Percebemos que apenas duas delas não foram contempladas ainda com um campus, como a de Miracema do Tocantins e do Jalapão, isso confirma a importante extensão de oferta da educação profissional no Estado do Tocantins.

Quadro 1 - As Microrregiões do Tocantins e a localização dos Campi:

\begin{tabular}{|l|l|l|l|l|}
\hline $\begin{array}{l}\text { Nome da } \\
\text { Microrregião }\end{array}$ & $\begin{array}{l}\text { Área em } \\
\text { km}^{2}\end{array}$ & População & $\begin{array}{l}\text { Número de } \\
\text { Municípios }\end{array}$ & Campi / Campi Avançados \\
\hline $\begin{array}{l}\text { Bico do } \\
\text { Papagaio }\end{array}$ & $15.767,856$ & 198.388 & 25 & Campus Araguatins \\
\hline Araguaína & $26.493,499$ & 269.498 & 17 & $\begin{array}{l}\text { Campus Araguaína } \\
\text { Campus Colinas do } \\
\text { Tocantins }\end{array}$ \\
\hline $\begin{array}{l}\text { Miracema do } \\
\text { Tocantins }\end{array}$ & $34.721,860$ & 145.535 & 24 & X \\
\hline Jalapão & $53.416,435$ & 65.705 & 15 & X \\
\hline Porto Nacional & $21.197,989$ & 304.110 & 11 & $\begin{array}{l}\text { Campus Porto Nacional } \\
\text { Campus Palmas } \\
\text { Campus Avançado Pedro } \\
\text { Afonso }\end{array}$ \\
\hline Rio Formoso & $51.405,340$ & 112.020 & 13 & $\begin{array}{l}\text { Campus Paraíso do } \\
\text { Tocantins Campus Avançado } \\
\text { Formoso do Araguaia } \\
\text { Campus Avançado Lagoa da } \\
\text { Confusão }\end{array}$ \\
\hline Gurupi & $27.445,292$ & 127.816 & 14 & Campus Gurupi \\
\hline Dianópolis & $47.172,643$ & 118.377 & 20 & Campus Dianópolis \\
\hline Total & $\mathbf{2 7 7 . 6 2 1 , 8 5 8}$ & $\mathbf{1 . 3 8 3 , 4 5 3}$ & $\mathbf{1 3 9}$ & $\mathbf{1 1}$ \\
\hline $\mathbf{k m}^{2}$ & & & & \\
\hline
\end{tabular}

Fonte: IBGE/SIDRA, 2010.

O quadro acima apresenta a localização dos campi/campi avançados por microrregiões no estado do Tocantins, destacando as áreas por quilômetros dessas microrregiões, população e número de municípios.

O IFTO oferece ensino técnico profissional em todas as modalidades, e curso superiores, de acordo com a necessidade de profissionais em boa parte do estado, promovendo a oportunizando desempregados se qualificarem e ingressarem no mundo do trabalho.

Para Moreira (2007), os Institutos devem ser capazes de possibilitar uma nova visão do mundo produtivo, que esteja de acordo com 0 desenvolvimento regional, bem como de sua sustentabilidade, e ter como consequência disso a qualidade de vida das pessoas através da educação. Para ele, "Somente por meio do conhecimento é possível a sociedade tomar 
consciência de seus problemas, participando das transformações sociais, econômicas e culturais, ajudando na formação integral do homem".

Somente por meio do conhecimento é possível a sociedade tomar consciência de seus problemas, participando das transformações sociais, econômicas e culturais, ajudando na formação integral do homem.

A partir desse questionamento, se considera que o conhecimento através da educação transforme integralmente o homem, e o deixe com capacidade para tomar consciência e interagir com problemas da sociedade.

\subsection{O Campus Araguatins}

Localizado na Microrregião do Bico do Papagaio, o Instituto Federal de Educação, Ciência e Tecnologia do Tocantins - Campus Araguatins foi criado pela lei $\mathrm{n}^{\circ}$ 11.892, de 29 de Dezembro de 2008. A partir da antiga EAFA Escola Agrotécnica Federal de Araguatins, criada pelo Decreto №. 91.673 de 20 de setembro de 1985, onde foi designada a funcionar os $1^{\circ}$ e $2^{\circ}$ graus profissionalizantes com habilitação em Agropecuária, Agricultura e Economia Doméstica, tendo sido inaugurada em 23 de março de 1988.

Hoje IFTO - Campus Araguatins, como autarquia federal, oferece cursos regulares divididos em modalidades diversificadas, como a Agropecuária, nas modalidades: Integrado ao ensino médio e Pós-Médio; Cursos Técnicos em Informática nas modalidades: integrado ao ensino médio, Proeja e Concomitante; Curso Técnico em Agroindústria na modalidade PROEJA (Última Turma); Cursos Superiores: Licenciatura em Ciências Biológicas, Licenciatura em Computação e Bacharelado em Ciências Agronômicas. Também cursos de curta duração, como Mulheres Mil e Pronatec. O Campus Araguatins tem como missão do Campus, segundo IFTO (BRASIL, 2009, p. 05),

preparar indivíduos para o exercício da cidadania, formando técnicos competentes que possam atuar como centro difusor de tecnologia, contribuindo dessa forma para 0 desenvolvimento e crescimento humano, para a melhoria da qualidade de vida das pessoas e para o progresso da Região e do país; visa também como futuro ser referência no ensino, pesquisa e extensão, com ênfase na inovação tecnológica de 
produtos e serviços, proporcionando o desenvolvimento regional sustentável.

Segundo UFT (2011) a região "é uma área de ocupação recente e sua população migrou principalmente do Maranhão e Piauí durante os anos 60 e 70. Majoritariamente agroextrativistas esta população implantou o sistema de produção baseado na "roça de toco", na coleta do coco do babaçu no agroextrativismo de frutas nativas, na pesca artesanal, na produção de mel e de farinha de mandioca de imensa importância social, ambiental, cultural e econômica".

As culturas que se destacam no Bico do Papagaio são a dos bovinos, suínos e aves na pecuária, e das hortaliças, mandioca, melancia, abacaxi, e outros produtos como o mel e o azeite de coco babaçu na agricultura. Sendo o mel por meio de extrativismo ou produção de apicultores de pequeno e médio porte, através dos criatórios apícolas (apiários/cortiços) e o azeite apenas pela atividades extrativista. A agropecuária é mantida pelos pequenos produtores, residentes em assentamentos, vilas e povoados. Os mesmos são responsáveis pelo desenvolvimento da agricultura familiar, onde os produtos e subprodutos em uma pequena porcentagem são consumidos pelos mesmos e a outra parte é destinada ao povo da cidade, que por sua vez são assíduos na aquisição dos produtos locais.

Sendo assim, o Campus Araguatins é referência no ensino da Agropecuária, logo o Instituído Federal de Educação oferece aos estudantes uma formação integral que proporcione habilidades e competências para sua inserção no mercado de trabalho, fazendo vínculo com os Arranjos Produtivos Locais (APL's).

\subsection{O Curso Técnico em Agropecuária}

O Projeto Pedagógico de Curso PPC (2013) Técnico em Agropecuária Integrado ao Ensino Médio do Campus Araguatins denota características específicas à agropecuária e tem como proposta organizar, regimentar e acompanhar as atividades pedagógicas. Segundo ele, a Instituição é fruto do Plano de Desenvolvimento da Educação (PDE) tendo sua criação positivada pela Lei n.o 11.892/2008, um novo modelo de instituição que nasceu da 
necessidade de abrir mais oportunidades na Educação Básica articulada com Educação Profissional e demais modalidades de Ensino bem como em Nível Superior.

O Objetivo Geral do Curso: é a formação de profissionais com competências e habilidades que os qualifiquem a atuar de forma responsável e consciente no setor agropecuário, determinando tecnologias de forma economicamente viáveis às várias regiões, inclusive promovendo 0 desenvolvimento sustentável.

Os Objetivos Específicos: com fulcro na Lei 9.394/96, e ainda com base no perfil de formação desejada o curso tem como especificidades:

- permitir a consolidação e o aprofundamento dos conhecimentos adquiridos no ensino fundamental, possibilitando o prosseguimento de estudos;

- possibilitar a preparação básica para o trabalho e a cidadania do estudante, para continuar aprendendo, de modo a ser capaz de se adaptar com flexibilidade a novas condições de ocupação ou aperfeiçoamento posteriores;

- aprimorar o estudante como pessoa humana, incluindo a formação ética e o desenvolvimento da autonomia intelectual e do pensamento crítico;

- possibilitar aos egressos conhecimentos Técnicos na área de Agropecuária, preparando-o para atuação com responsabilidades e ética profissional;

- interagir para a compreensão dos fundamentos científico-tecnológicos dos processos produtivos, relacionando a teoria com a prática, no ensino de cada disciplina.

O Perfil do Egresso: o egresso será capaz de:

- planejar, executar, acompanhar e fiscalizar todas as fases dos projetos agropecuários;

- administrar propriedades rurais;

- elaborar, aplicar e monitorar programas preventivos de sanitização na produção animal, vegetal e agroindustrial;

- fiscalizar produtos de origem vegetal, animal e agroindustrial; 
- realizar medição, demarcação e levantamentos topográficos rurais;

- atuar em programas de assistência técnica, extensão rural e pesquisa.

\section{As Competências e Habilidades:}

- qualificar os estudantes por meio do desenvolvimento de competências e habilidades específicas nas áreas de: tecnologia agrícola, pecuária e agroindustrial, associativismo e cooperativismo, gestão e economia rural, construções e instalações rurais, irrigação, manejo de sistemas agroflorestais, cultivo de culturas olerícolas, culturas sazonais, jardinocultura e fruticultura, criações diversas como: avicultura, piscicultura, apicultura, suinocultura, ovinocultura, bovinocultura e equinocultura;

- habilitar e qualificar o profissional técnico em Agropecuária atendendo as atribuições inerentes ao exercício da profissão do Técnico Agrícola;

- proporcionar condições para que ao final do Curso o Técnico em Agropecuária desenvolva atividades como: conduzir a execução técnica dos trabalhos de sua especificidade; prestar assistência técnica no estudo e desenvolvimento de projetos e pesquisas tecnológicas; orientar e coordenar a execução dos serviços de manutenção de equipamentos e instalações;

- permitir a capacidade ao técnico para fornecer assistência técnica na compra, venda e utilização de produtos e equipamentos especializados; responsabilizar-se pela elaboração e execução de projetos, compatíveis com sua formação profissional; planejar, executar, acompanhar e fiscalizar todas as fases dos projetos agropecuários; administrar propriedades rurais; monitorar programas preventivos de sanidade e fiscalização na produção animal, vegetal e agroindustrial; realizar medição, demarcação e levantamentos topográficos rurais; bem como atuar em programas de assistência técnica, extensão rural e pesquisa.

\section{A Organização Curricular:}

- Os planos de ensino são elaborados considerando as áreas de conhecimento: Linguagens, Matemática, Ciências da Natureza, Ciências 
Humanas, as Diretrizes e Bases da Educação Nacional e as Diretrizes Curriculares Nacionais para a Educação Profissional de Nível Médio.

- O trabalho de ensino e aprendizagem é desenvolvido por meio de aulas teóricas e práticas sob orientação dos docentes, técnicos agropecuários, técnicos de laboratório e demais profissionais do âmbito pedagógico do campus. As aulas acontecem em salas apropriadas, nos setores de produção, nos laboratórios e nas unidades de processamento.

- Adota-se, como prática pedagógica a participação dos estudantes em congressos, seminários e workshops, visitas técnicas, atividades em equipe, defesa e apresentação de seminários e defesas de estágios. As aulas práticas são desenvolvidas na área aberta do Campus, nas unidades educativas de produção, bem como nas visitas técnicas. Com o desenvolvimento e defesa de projetos e atividades de monitoria complementa-se a junção da teoria com a prática.

O PPC (Projeto Pedagógico de Curso Técnico em Agropecuária Integrado, 2013) aponta o Campus como produtor e disseminador de conhecimento na Formação Inicial e Continuada, na Educação Profissional Técnica de Nível Médio e na Educação Superior. De modo a promover a qualificação integral de seus estudantes, contribuindo na formação de profissionais para o mercado de trabalho e possibilitando a continuidade dos estudos em nível superior.

O Curso na modalidade Educação profissional - Educação Básica: forma de articulação: Integrada Ensino Médio, retrata as seguintes características: carga horária total de 3920 horas; duração de 03 anos; área de conhecimento referente à agropecuária; eixo tecnológico de recursos naturais; regime de oferta presencial; com matrículas anuais; funcionamento diurno; oferta anual de 200 vagas.

O público-alvo consiste em estudantes que concluíram o ensino fundamental e que almejam ingressar em um Ensino Médio que tenha uma disposição curricular a forma integrada com a formação profissional em agropecuária; o acesso dos estudantes ocorre por meio de processo seletivo com questões objetivas e prova de redação; o estudante deve cumprir carga horária de no mínimo 160 horas de estágio curricular supervisionado; as 
atividades acadêmicas ocorrem nas Unidades Educativas de Produção (UEPs) já existentes no Campus nas áreas de Agricultura, Zootecnia, Agroindústria e Engenharia Agrícola.

Os docentes existentes no quadro atendem a demanda dos cursos, sendo um total de 65 docentes para referida área. Ressalta-se que o curso é divulgado por meio da Imprensa escrita, internet, rádio, televisão e ainda por meio de comissão própria do campus que visitam os municípios da Mesorregião do Bico do Papagaio, (PPC, 2013).

Uma das justificativas da oferta do curso é em decorrência de a Instituição de Ensino estar situada no município de Araguatins e ter como atividades econômicas a agricultura, a pecuária e o extrativismo vegetal, como já foram antes mencionados, além de pequenas indústrias, pesca e comércio varejista.

Alguns indicadores foram levados em consideração na escolha da oferta conforme constam nos quadros a seguir:

Tabela 1- Número de Assentamentos, área total e famílias assentadas por municípios na Região do Bico do Papagaio.

\begin{tabular}{|l|c|c|c|}
\hline Municípios & $\begin{array}{l}\text { Quantidade } \\
\text { de } \\
\text { assentamentos }\end{array}$ & Área Total (há) & Famílias Assentadas \\
\hline 1-Arguianópolis & 2 & 4024,24 & 119 \\
\hline 2-Ananás & 2 & $6.424,33$ & 96 \\
\hline 3-Angico & 1 & $4.028,28$ & 44 \\
\hline 4-Araguatins & 20 & $49.265,91$ & 1.335 \\
\hline 5-Augustinóolis & 8 & $19.234,78$ & 507 \\
\hline 6-Axixá do Tocantins & 3 & $10.962,46$ & 378 \\
\hline 7-Buriti do Tocantins & 2 & $3.538,30$ & 114 \\
\hline 8-Cachoeirinha & 1 & $3.301,01$ & 76 \\
\hline 9-carrasco Bonito & 5 & 926,31 & 33 \\
\hline 10-Darcinópolis & 12 & $22.003,41$ & 369 \\
\hline 11-Esperantina & 3 & $8.454,68$ & 202 \\
\hline 12-Itaguatins & 1 & $9.959,28$ & 102 \\
\hline 13-Luzinópolis & 4 & $1.889,65$ & 65 \\
\hline $\begin{array}{l}\text { 14-Maurilândia } \\
\text { Tocantins }\end{array}$ & 3 & $9.961,33$ & 219 \\
\hline $\begin{array}{l}\text { 15-Palmeiras } \\
\text { Tocantins }\end{array}$ & 4 & $11.083,03$ & 355 \\
\hline 16-Praia Norte & 5 & $16.608,36$ & 257 \\
\hline 17-Riachinho & 5 & $5.569,19$ & 81 \\
\hline 18-Sampaio & & $11.717,71$ & 210 \\
\hline $\begin{array}{l}\text { 19-São Bento do } \\
\text { Tocantins }\end{array}$ & & & \\
\hline
\end{tabular}




\begin{tabular}{|c|c|c|c|}
\hline $\begin{array}{l}\text { 20-São Miguel do } \\
\text { Tocantins }\end{array}$ & 7 & $14.394,66$ & 285 \\
\hline $\begin{array}{l}\text { 21-São Sebastião do } \\
\text { Tocantins }\end{array}$ & 6 & $10.904,54$ & 285 \\
\hline $\begin{array}{lll}22 \text { 2-Sítio Novo do } \\
\text { Tocantins }\end{array}$ & 5 & $6.673,76$ & 157 \\
\hline 23-Tocantinópolis & 1 & 452,60 & 12 \\
\hline 24-Xambioá & 4 & $11.342,99$ & 307 \\
\hline
\end{tabular}

Fonte: PPC (Curso Técnico em Agropecuária, 2013).

Segundo Guilhoto et al (2013) a agricultura familiar desempenha um papel relevante que chega a superar a agricultura patronal na produção, por exemplo, de carnes suínas e de aves, leite, ovos, batata, trigo, cacau, banana, café, milho, feijão, tomate, mandioca e laranja. A grande flexibilidade de adaptação da agricultura familiar aos diferentes processos de produção e variedade de fontes de renda a coloca como parceira importante na estratégia para a promoção de um novo modelo de desenvolvimento. Outra vantagem refere-se à elevada capacidade de absorver mão de obra, o que a transforma numa alternativa socialmente desejada, economicamente produtiva e politicamente coerente para atacar os grandes problemas sociais do mundo urbano derivados de um modelo de desenvolvimento excludente.

Uma das preocupações do processo de ensino e de aprendizagem do campus é que os egressos após o término do curso desempenhem tarefas ligadas aos Arranjos Produtivos Locais (APL's) e para isso, os estágios são feitos nos principais ramos de atividades presentes na região onde se localiza o campus.

O quadro abaixo apresenta o número de alunos que fizeram estágio no ano de 2011 em ramos de atividades as quais puderam vivenciar situações concretas da agricultura e pecuária.

Quadro 2 - Ramos de atividades das Empresas Concedentes de Estágio para o Curso de Agropecuária

\begin{tabular}{|l|l|l|l|}
\hline № & Ramo de atividade & Número de estagiários & Percentual \\
\hline 1 & Apicultura & 03 & $2,85 \%$ \\
\hline 2 & Assistência e extensão rural & 24 & $22,80 \%$ \\
\hline 3 & Avicultura & 04 & $3,80 \%$ \\
\hline 4 & Bovinocultura & 18 & $17,20 \%$ \\
\hline 5 & Comércio de produtos agropecuários & 11 & $10,40 \%$ \\
\hline 6 & Defesa agropecuária & 12 & $11,50 \%$ \\
\hline
\end{tabular}




\begin{tabular}{|l|l|l|l|}
\hline 7 & Equinocultura & 02 & $1,90 \%$ \\
\hline 8 & Fruticultura & 05 & $4,80 \%$ \\
\hline 9 & Inseminação artificial & 06 & $5,80 \%$ \\
\hline 10 & Mecanização agrícola & 03 & $2,85 \%$ \\
\hline 11 & Olericultura & 06 & $5,70 \%$ \\
\hline 12 & Produção de óleo de coco babaçu & 02 & $1,90 \%$ \\
\hline 13 & Reforma agrária & 09 & $8,50 \%$ \\
\hline TOTAL & 105 & $100 \%$ \\
\hline
\end{tabular}

(Fonte: CIEC/Campus Araguatins, 2011)

Os 105 estudantes fizeram seus estágios em 13 áreas distintas. Os estudantes foram divididos em 51 municípios dos seguintes estados: a) Maranhão (29 estágios); b) Pará (27 estágios); e c) Tocantins (49 estágios). É possivel perceber que a bovinocultura, assistência e extensão rural, ressaltam-se como arranjos produtivos, porque os municípios tocantinenses possuem um grande número de assentamentos de reforma agrária, e estão ligados à produção leiteira. É notório que o estágio é importante para o estudante refletir e vivenciar a realidade vivida sobre as teorias que foram trabalhadas durante 0 curso. $O$ artigo $1^{\circ}$ da Lei $n^{\circ}$ 11.788/08 define o estágio como:

Art. 1ำ Estágio é ato educativo escolar supervisionado, desenvolvido no ambiente de trabalho, que visa à preparação para o trabalho produtivo de educandos que estejam frequentando o ensino regular em instituições de educação superior, de educação profissional, de ensino médio, da educação especial e dos anos finais do ensino fundamental, na modalidade profissional da educação de jovens e adultos. (BRASIL, 2008).

Sendo assim, é notório que o estágio desenvolve a atividade prática do aluno, a sua responsabilidade, a criticidade e demais atitudes e habilidades profissionais esperadas em sua formação.

O quadro a seguir, apresenta o resultado de um questionário aplicado nos anos de 2009 e 2010 em um encontro de alunos egressos organizado anualmente pelo campus, descrevendo à empregabilidade desses alunos em relação à quantidade e porcentagem. 
Quadro 3 - Empregabilidade dos Egressos do Campus Araguatins

\begin{tabular}{|l|c|c|c|c|}
\hline \multirow{2}{*}{$\begin{array}{l}\text { SITUAÇÃO QUANTO À } \\
\text { EMPREGABILIDADE }\end{array}$} & \multicolumn{2}{|l|}{ ENCONTRO DE EGRESSOS - 2009 } & \multicolumn{2}{l|}{ ENCONTRO DE EGRESSOS - 2010 } \\
\cline { 2 - 5 } $\begin{array}{l}\text { Trabalhando na área de } \\
\text { formação }\end{array}$ & 32 & $39,02 \%$ & 34 & $39,08 \%$ \\
\hline $\begin{array}{l}\text { Trabalhando fora da } \\
\text { área de formação em }\end{array}$ & 23 & $28,05 \%$ & 30 & $34,48 \%$ \\
\hline $\begin{array}{l}\text { Trabalhando } \\
\text { propriedade da família }\end{array}$ & 01 & $1,22 \%$ & 02 & $2,30 \%$ \\
\hline $\begin{array}{l}\text { Egresso sem inserção no } \\
\text { mercado de trabalho }\end{array}$ & 26 & $31,71 \%$ & 21 & $24,14 \%$ \\
\hline \begin{tabular}{l} 
TOTAL----------------- \\
\hline
\end{tabular} & 82 & $100 \%$ & 87 & $100 \%$ \\
\hline
\end{tabular}

(Fonte: CIEC/Campus Araguatins, 2011)

É interessante levar em consideração, antes da análise dos dados sobre a empregabilidade, a relação trabalho e educação feita por Cordão (2010, p. 110 a 111).

A Educação profissional é essencialmente um trabalho educativo e cumpre a função de garantir o direito do cidadão à educação, uma educação q o conduza ao mercado de trabalho, não da forma em que está, mas um mercado de trabalho em constante mudança. Por isso, é fundamental a articulação entre trabalho, ciência e tecnologia. Trata-se de garantir que 0 cidadão se insira no mercado de trabalho em condições de modificá-lo, de acompanhar as mudanças em condições de se atualizar e desenvolver uma aprendizagem permanente.

Os percentuais de $39,02 \%$ e $39,08 \%$ com empregabilidade no ramo da agropecuária parecem significativo, contanto é importante analisar que foram pesquisados no Encontro dos Egressos dos anos já citados e com alguns exalunos presentes no evento. É necessária uma pesquisa com uma maior quantidade de entrevistados e sua empregabilidade em outros anos para se ter maior precisão nos resultados. 


\section{A INVESTIGAÇÂO E SEU SUPORTE TEÓRICO: CONSTRUCTO DE} FAULSTICH, A TEORIA DA SOCIOTERMINOLOGIA E A VARIAÇÂO EM TERMINOLGIA

A investigação utilizou como suporte teórico o constructo postulado por Faulstich (1995-2003), a Socioterminologia, e a variação em terminologia como já antes mencionados, neste capítulo descreveremos em detalhes a origem dessas teorias.

A perspectiva do uso da base funcional para esse estudo é justificada por se acreditar que os termos podem apresentar variante cujos comportamentos podem ser linguísticos e de registro. A categorização de um tipo de variação pode se dar com base em alguns aspectos:

$\checkmark$ a interpretação semântica é a base para análise do termo;

$\checkmark$ os termos são analisados sob o ponto de vista funcional;

$\checkmark$ os usos escrito e oral dos termos são levados em conta.

Apresentamos então, as teorias que deram embasamento a pesquisa desde os primeiros estudos, constituição, metodologia e opiniões de vários pesquisadores.

\subsection{A Teoria da Socioterminologia}

No Brasil, os primeiros estudos ligados à Socioterminologia ${ }^{3}$ foram iniciados em 1995, pela pesquisadora Enilde Faulstich. Seus estudos conduziram as pesquisas a caminhos de reflexões e soluções metodológicas que explicassem a variação, a constituição e o funcionamento dos termos, as quais originaram um constructo teórico da variação em Terminologia, adotado nesta pesquisa.

Ao mesmo tempo, em Barcelona, surge a Teoria Comunicativa da Terminologia (TCT), a exemplo da teoria proposta por Faulstich, criticava os

\footnotetext{
${ }^{3}$ Socioterminologia é a disciplina que se ocupa da identificação e da categorização das variantes linguísticas dos termos em diferentes tipos de situação de uso da língua. Para que o linguista, especialista em terminologia, desenvolva seu trabalho de pesquisa, é preciso levar em conta critérios básicos de variação terminológica no meio social, bem como critérios etnográficos, porque as comunicações entre membros da comunidade em estudo podem gerar termos diferentes para um mesmo conceito ou mais de um, (FAULSTICH, 1995).
} 
propósitos normalizadores da Terminologia, criado por Eugen Wüster, teórico que se preocupava com a metodologia e a norma aplicadas à terminologia, sendo essa, um instrumento que visava à "eliminação das ambiguidades nas comunicações científicas e técnicas”, na opinião de Rondeau apud Cruz, (2005, p.34).

Faulstich (1995) afirma que a denominação Socioterminologia passou a ser defendida por vários linguistas em decorrência do reconhecimento que as terminologias estão sujeitas à variação e adquire, portanto, um caráter teórico e defende que os termos sejam estudados em sua dimensão discursiva e reconhece a necessidade de se tipificar a variedade dos termos coletados.

Termo e palavra compõem a competência do falante ideal, competência geral, quando comum a todos e/ou competência específica, quando própria de determinado grupo de falantes. O léxico de qualquer língua constitui um vasto universo de limites imprecisos e indefinidos. Abrange todo 0 universo conceptual dessa língua, (BIDERMAN, 2001, p. 179).

Cabré (1996, p. 5) afirma que o conjunto de termos de uma área especializada representa o conhecimento dessa área e ao mesmo tempo denomina seus conceitos, sendo, portanto, uma maneira de conhecer e de determinar. Da mesma forma, os termos também permitem a transferência do conhecimento da especialidade são, portanto, unidades de comunicação e expressão. Segundo ela mesma (1993, p. 37), "para os especialistas, a terminologia é o reflexo formal da organização conceitual de uma especialidade, e um meio inevitável de expressão e comunicação profissional".

Krieger (2001, p. 47) explica que é importante considerar o funcionamento da linguagem com toda a sua complexidade para descrever, em melhores condições, a especificidade dos contextos discursivos nos quais os termos se manifestam em toda a sua diversidade de configurações.

O conteúdo de um termo, afirma Barros (2004, p. 58), é relativo a um domínio e a uma situação de uso. Dentro de um sistema conceptual, o valor de um termo é dado pelo lugar que ocupa na estrutura, podendo ocupar lugares diferentes, de acordo com os critérios de organização do sistema de conceitos. 
"Os termos não pertencem a um domínio, mas são usados em um domínio com valor singularmente específico" (CABRÉ, 1999, p. 124).

Faulstich (2003, p. 11), em suas pesquisas, comenta que "os estudos terminológicos focalizam mais o conteúdo semântico do que a forma de um termo e a função que este desempenha no discurso especializado". Segundo a autora, tanto o conteúdo quanto a forma são entidades que ordenam o termo. Também é em Faulstich (1995-2003) que encontraremos o constructo da Teoria da variação terminológica.

\subsection{A Variação em terminologia}

Discutimos aqui a ocorrência da variação ou não em terminologia, do ponto de vista de alguns autores. Porém, para o estudo do pensamento desses escritores destacaremos o contexto histórico e cultural em que foram gerados os princípios fundados de um novo campo de estudo, a Terminologia.

Esse estudo se iniciou através da tese de Wüister (1998) sobre a padronização da padronização da linguagem usada na engenharia eletrotécnica, que desenvolvia uma pesquisa teórica e aplicada, voltada para a univocidade da comunicação num contexto histórico em que o mundo vivenciava os horrores da guerra.

A disciplina Terminologia começou a tomar proporções consideráveis, após a Segunda Guerra Mundial, por meio da pesquisa de Wüster, com a implantação do projeto de um grande dicionário técnico em inglês e francês com suplemento em alemão; o professor tinha a pretensão de superar a polissemia e as imprecisões da linguagem técnica e científica, não havendo muito sucesso, elaborou um glossário com uma nova metodologia, e o objetivo era que ele assegurasse a padronização dos termos usados na ciência e na técnica, Maciel (2007, p.372).

O tema teve abrangência e interessou a muitos pesquisadores, após a publicação dos trabalhos proferidos por Wüster na universidade de Viena entre os anos de 1942 e 1974. Esses trabalhos foram todos compilados pelo pesquisador conhecido como fiel seguidor de Wüster, Helmuth Felber. Dentre 
esses trabalhos estavam: artigos, aulas, ciclos de conferência e pronunciamentos. A compilação gerou a publicação que recebeu o nome de Einführung in die allgemeine Terminologielehre und terminologische Lexikographie, mais tarde ficou conhecido como a Teoria Geral da Terminologia, a TGT.

A TGT realça a ideia de que o conhecimento e a língua são controversos, um se mostra como a perfeição da ciência, o outro com as incorreções que possui o saber comum, que tem tendência a sofrer variações. A fundamentação teórica começou a ser questionada por vários autores.

Em 1931, Eugen Wüster, no seu Die internationale Sprachnormung in der Technik, besonders in der Elektronik, preservava em sua tese a ideia de que a terminologia não deveria sofrer ambiguidades, acometidas por denominações plurivalentes (termos homônimos e polissêmicos) e por denominações múltiplas (termos sinônimos). Segundo essa perspectiva, interpretavam-se como anômalos os casos que gerassem ambiguidade e motivassem a variação, de acordo com Faultish (2001).

Para Wüster (1998, p.17-18), se denomina "variación lingüística toda pertubación de la unidad linguística", que se construía através do surgimento de sinônimos ou homônimos de variação, ele chama atenção para a necessidades de se fazer distinção entre a "cisões" (variação) monolíngue que pode ser regional e pode ocorrer entre campos temáticos, e "cisões" (variações) linguística interlíngues, que se dá quando diferentes termos são empregados para designar um só conceito em várias línguas.

O objetivo de Wüster era eliminar as variações por meio da normatização dos termos, ele se preocupava em expandir a transferência da tecnologia e o intercâmbio de informações no âmbito internacional. Para ele, as variações eram definidas por unidades biunívocas e monorreferenciais, dentro de uma área de especialidade.

Faulstich (1995, p. 20) afirma que a terminologia está voltada à observação do uso do termo em contextos de língua oral e de língua escrita, atitude que implica a possibilidade de identificação de variantes dentro de um 
mesmo contexto ou em diferentes contextos em que o mesmo termo é usado e que a variação e terminologia não se confrontam na abordagem atual. Pelo contrário, defendemos que a terminologia é passível de variação porque faz parte da língua, é heterogênea por natureza, e é de uso social.

De acordo com Finatto (1996, p. 64-65), a Terminologia, dependendo do quadro teórico em que se argumenta, pode ser definida como um prolongamento temático da Linguística Aplicada que se ocupa do fenômeno da designação nas línguas de especialidade.

Para Sager apud Finatto (1996, p. 64-68), pode também ser pensada como um ponto de encontro entre linguística, ciência da informação, linguística computacional, e informática, sem que, contudo, devêssemos entendê-la como uma disciplina propriamente dita. Nesse sentido o autor compreende Terminologia como estudo ou campo de atividade relacionado com a compilação, descrição, processamento e apresentação de termos, ou itens lexicais pertencentes a áreas de uso especializado em uma ou mais línguas. Enquanto estudo é também definida como uma teoria para a descrição e explicação das relações entre conceitos e termos.

Finatto (1996) comentaaque a variação é amplamente verificada no uso especializado de qualquer língua, independente da área de conhecimento que se queira examinar, é perfeitamente previsível sua ocorrência, em maior ou menos grau, para o caso de língua de especialidade compartilhado por países de mesmo idioma, como é o caso do português brasileiro lusitano. A título de exemplo, observa-se na constituição de um repertório da terminologia do meio ambiente, em fase da elaboração em Portugal, na subárea da Química, como exemplo constatada desigualdades entre termos. Enquanto para Portugal existem ácidos gordos voláteis e anidrido sulfúreo, no Brasil os mesmos termos são conhecidos por ácidos graxos voláteis e anidrido sulfuroso. Isso nos mostra que várias constatações se efetivaram em relação à existência de variação na língua de especialidade.

Cabré (1993, p.157) afirma que há variações na linguagem de especialidade diferentes, e diz: 
(...) toda linguaje de especialidade, em la medida em que es um subconjunto del general, participa de sus mismas características; se trta, pues, de um código unitario que permite variaciones (...) La variacion de pues, de um código unitário que permite variaciones (...) La variacion de los linguajes de especialidade sigue los mismos critérios de diversificacion sistemática referidos a la lengua: las modalidades dialectales, los registros y las variedades estilísticas. Em efecto, los linguajes especializadas, por el hecho de ser subcódigos del linguaje general, participan de sus mismas modalidades dialectales y funcionales - aunque de forma mas restringida puesto que la funcion comunicativa es la prioritária entre especialistas (p.157).

A Terminologia é um conjunto interdisciplinar para qual convergem três teorias principais e a Teoria do Conhecimento, a Teoria da Comunicação, e a Teoria da Linguagem. Ao mesmo tempo, a Terminologia é uma área transdisciplinar, porque atravessa e mergulha em todas as disciplinas e profissões, posto que nenhuma atividade, científica, técnica, artística ou artesanal, pode dispensar-lhe o concurso nos procedimentos de constituição e verbalização dos conceitos, Cabré (Apud Maciel, 1999: 93-106).

Ainda para Timbane (2012, p.152) encontram-se termos científicotecnológica variados, dentro da mesma área de conhecimento em uma mesma língua, isso se justifica pela diferença sociolinguísticas existente entre os falantes e afirma também que

a variação linguística em terminologia é resultado da correlação entre fatores linguísticos e sociais bem como da covariação de mudanças associadas ao espaço geográfico e do tempo ou período. Este é um fenômeno permanente que responde às necessidades da comunidade dos falantes, atuando sempre de forma lenta, gradual. Sendo assim as novas realidades, a criação de novos objetos e contato linguístico no mesmo espaço geográfico faz que surjam novos itens lexicais, ou melhor, novos termos.

De acordo com Cruz (2005, p.44)

como todas as unidades lexicais, os termos não ocorrem isoladamente, mas combinados com outras unidades do discurso, em estruturas sintáticas específicas, combinatórias, expressões idiomáticas, em frases onde desempenham funções. Por outro lado, as unidades lexicais especializadas não ocorrem em discursos artificiais, porque, também os termos científicos e técnicos estão sujeitos à variação, no tempo, no espaço e na sociedade. 
Enfim, nosso trabalho é baseado na ideia de que é possível encontrar variação no léxico especializado. Portanto, decidimos nos valer da Socioterminologia e da teoria da variação proposta por Faulstich (1998). Descreveremos assim em detalhes o constructo teórico.

\subsection{O Constructo da Teoria da Variação de Faulstich}

Faulstich (1995) propõe uma discussão em torno da variação em terminologia, no quadro de uma interpretação socioterminológica, considerando que as variantes são resultantes dos diferentes usos que a comunidades, em sua diversidade social, linguística e geográfica, faz do termo. Para a autora, descrever a terminologia em variação, é necessário ter em conta qual é o padrão de língua que está sendo considerado. Diante disso, é possível criar parâmetros para objetivo abordado e observar se a descrição tende à normalização, a normatização, a hipernormalização, ou se tem uma postura ideológica de natureza puramente preconceituosa, afirma Faulstich (2001, p.11-40). Para ilustrar essa ideia, a autora apresenta as seguintes reflexões:

Um uso normal tende a normalizar-se no meio da comunidade
que o adota; por sua vez, um uso normativo resulta da
recomendação de uma "autoridade" que prescreve qual deve
ser o "bom uso" da língua e na língua e, comumente, tal
recomendação aparece registrada nos documentos prescritivos
e normativos. Neste contexto, o termo normalização é
ambíguo, porque tanto pode significar o processo de tornar
normal os usos linguísticos, quanto pode significar um processo
impositivo de "bom uso". A este último significado cabe mais a
expressão normativização, neologismo que poderia substituir o
termo linguístico normalização. O conceito de normalização
está mais relacionado ao de padronização e de uniformização
e, até mesmo, ao de harmonização linguística do que ao de
imposição. (Faulstich, 1999a, p. 172).

A pesquisadora cria em 1995, a primeira tipologia de variação em terminologia, que resultou em cinco tipos de variantes, quais sejam: i) variante gráfica, ii) variante lexical, iii) variante morfossintática, iv) variante socioprofissional e v) variante topoletal. Após essa tipologia apresentada, houve algumas revisões feitas, e entre elas a eliminação da variante socioprofissional, por ser considerada óbvia, já que todo termo pertence a linguagem de especialidade. 
Em 1998, a autora elabora cinco postulados para a teoria da variação em terminologia. Foi então estabelecido que o processo da variação se dá dentro de um constructo teórico, em variáveis que produzem variantes que funcionam nas línguas, de acordo com as lacunas que elas venham a preencher. Os postulados são:

a. Dissociação entre estrutura e homogeneidade ou univocidade ou monorreferencialidade, associando-se a estrutura terminológica a noção de heterogeneidade ordenada;

b. Abandono do isomorfismo categórico entre termo-conceito-significado;

c. Aceitação de que, sendo a terminologia um fato da língua, ela acomoda elementos variáveis e organiza uma gramática;

d. Aceitação de que a terminologia varia e de que essa variação pode indicar uma mudança em curso;

e. Análise da terminologia em co-textos linguísticos e em contextos discursivos.

De acordo com Faulstich (2001, p.11-40), foi formulado o esquema básico de variação, com base nos postulados, que em um plano superior possuem as categorias (variantes concorrentes, coocorrentes e competitivas) e, no plano seguinte, as subcategorias (variante formal, sinônimos e empréstimos) definidas a seguir.

As VARIANTES CONCORRENTES podem concorrer entre si, e permanecer, como tais, no estrato, ou que podem concorrer para a mudança. Nessa condição, uma variante que concorre com outra ao mesmo tempo não ocupa o mesmo espaço. Por causa da própria natureza da concorrência. Se uma variante está presente no plano do discursivo, outra não aparece. Assim as variantes concorrentes, nesse papel, se organizam em distribuição complementar. São variantes formais. A variante formal é uma forma linguística ou forma exclusiva de registro que corresponde a uma das alternativas de denominação para uma mesmo referente, podendo concorrer num contexto determinado. Classificam-se em variantes terminológicas 
linguísticas e variantes terminológicas de registro (FAULSTICH, 2001, p. 26 ). Conforme pode ser observado na figura subsequente:

Figura 1: Constructo teórico da variação em terminologia

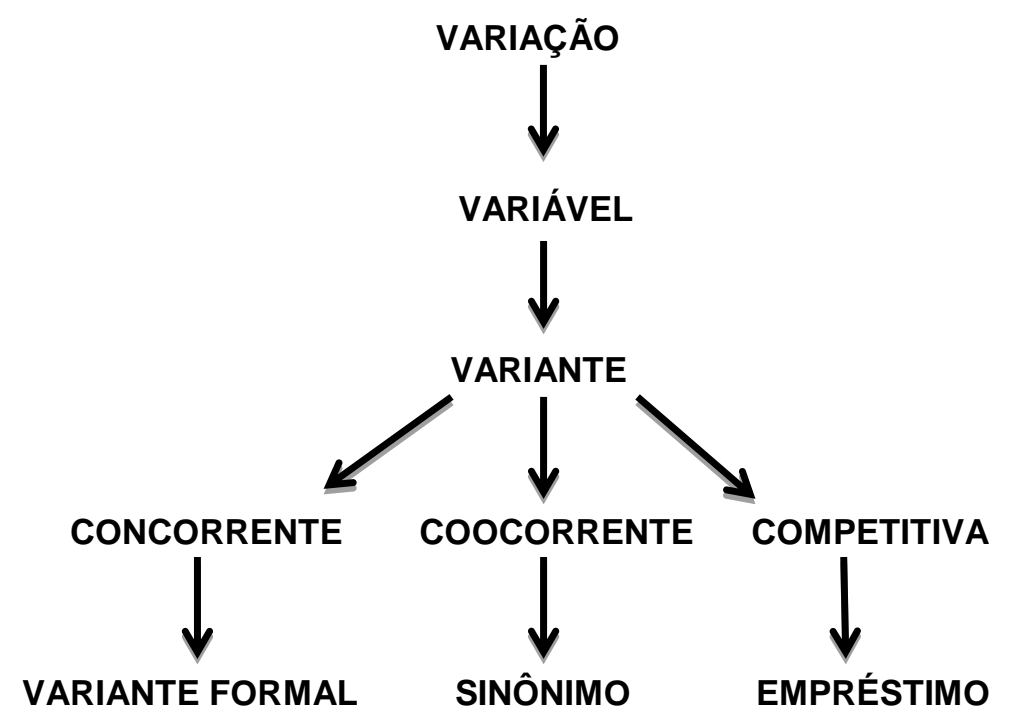

As variantes terminológicas linguísticas são aquelas cujo fenômeno propriamente linguístico determina o processo de variação. São obedecidos alguns princípios para classificação dessas variantes, como:

a) a interpretação semântica é a base para análise do termo;

b) as unidades terminológicas são analisadas sob o ponto de vista funcional;

c) os subsistemas da língua portuguesa constituem o fundo linguístico de análise;

d) os usos escritos e orais dos termos são levados em conta.

O grupo das variantes terminológicas linguísticas se constitui pelos seguintes tipos:

1. Variante terminológica morfológica, a que apresenta alternância de estrutura de ordem morfológica na constituição do termo, sem que o conceito se altere, como gado de leite, gado leiteiro, na cultura da agropecuária. 
2. Variante terminológica lexical, em que algum item da estrutura lexical de um termo sofre apagamento, mas o conceito do termo não se altera como, em melhoramento genético \de plantas e melhoramento / O / de plantas.

3. Variante terminológica fonológica, a que a escrita pode surgir de formas decalcadas da fala, como chacra em relação a chácara, acero em relação a aceiro.

4. Variante terminológica gráfica a que se apresenta como forma gráfica diversificada de acordo com as convenções da língua, como pólen e polem. Esse tipo de variação decorre da forma escrita do termo.

5. Variante terminológica sintática, em que há alternância entre duas construções sintagmáticas. Neste caso, a variação se processa na substituição de uma parte do item lexical por outro de estrutura semelhante, formando uma mesma unidade terminológica, como em vetor de clonagem genética e vetor de clonagem de genes (Faulstich, 2001, p.28).

No que se refere à presença de variantes concorrentes, de acordo com Faulstich (1999), ocorre "quando uma variante concorre com outra ao mesmo tempo não ocupa o mesmo espaço, por causa da própria natureza da concorrência". Citem-se, por exemplo, o caso das variantes terminológicas de discurso, nos seguintes exemplos já coletados: galpão aviário, galpão de aves (discurso técnico) e poleiro e galinheiro (discurso vulgarizado).

A classificação das variantes de registro obedece aos seguintes princípios:

a. Os termos que são recolhidos no discurso real da linguagem de especialidade;

b. Os termos que pertencem à variedade sócio profissional;

c. Os termos que são recolhidos de textos de procedência diversificada, que tratam do mesmo assunto; 
d. Os termos que são recolhidos de discursos com maior ou menor grau de formalismo, que tratam do mesmo assunto;

e. Os termos que são recolhidos de textos redigidos em épocas diferentes, que tratam do mesmo assunto:

f. Os usos escrito e oral são levados em conta.

As variantes de registro classificam-se em geográfica, de discurso e temporal, como está descrito a seguir:

Variante terminológica geográfica, de comunidades linguísticas geograficamente limitadas por fatores políticos, econômicos ou culturais, ou de influências que cada região sofreu durante sua formação. Como exemplo, estão os termos da linguagem agropecuária, galinha d'angola, angolista, capote, guiné, cocar e tô fraco, usados na região norte do Tocantins.

Variante terminológica de discurso, a que decorre da sintonia comunicativa que se estabelece entre elaborador e usuário de textos científicos e técnicos, podendo ser estes mais ou menos formais.

Variante terminológica temporal, aquela que se configura como o mais usual no processo de variação e mudança, em que uma forma se fixe como a preferida. Lamberti (apud CRUZ, 2005, p. 52) chama atenção para um princípio acerca da função da variação, assim estabelecida:

A VARIACÃO ocorre pela ação do movimento gradual do termo no tempo e no espaço e é provocada pela função de uma dada VARIAVEL (função e variável são conceitos compreendidos dentro de um espectro funcional) em que (t) representa um conjunto de termos passíveis de serem atualizados com diferentes valores para uma dada situação; (f) representa uma função responsável pela determinação de um valor específico. A regra geral fica assim estabelecida: $(\mathfrak{f})$ e representada por (t), em que (t) e uma variável; (t) poderá funcionar com qualquer valor, dependendo do desempenho de $(f)+(t)$. A posição da variável ( $t$ ) permite que seja atualizada qualquer uma das variantes.) 
A figura abaixo representa um modelo reduzido das variantes concorrentes de acordo com o constructo de Faulstich, apresentando suas subdivisões em formais linguísticas e formais de registro.

\section{Figura 2: Constructo teórico da variação em terminologia}

(modelo reduzido: as variantes concorrentes)

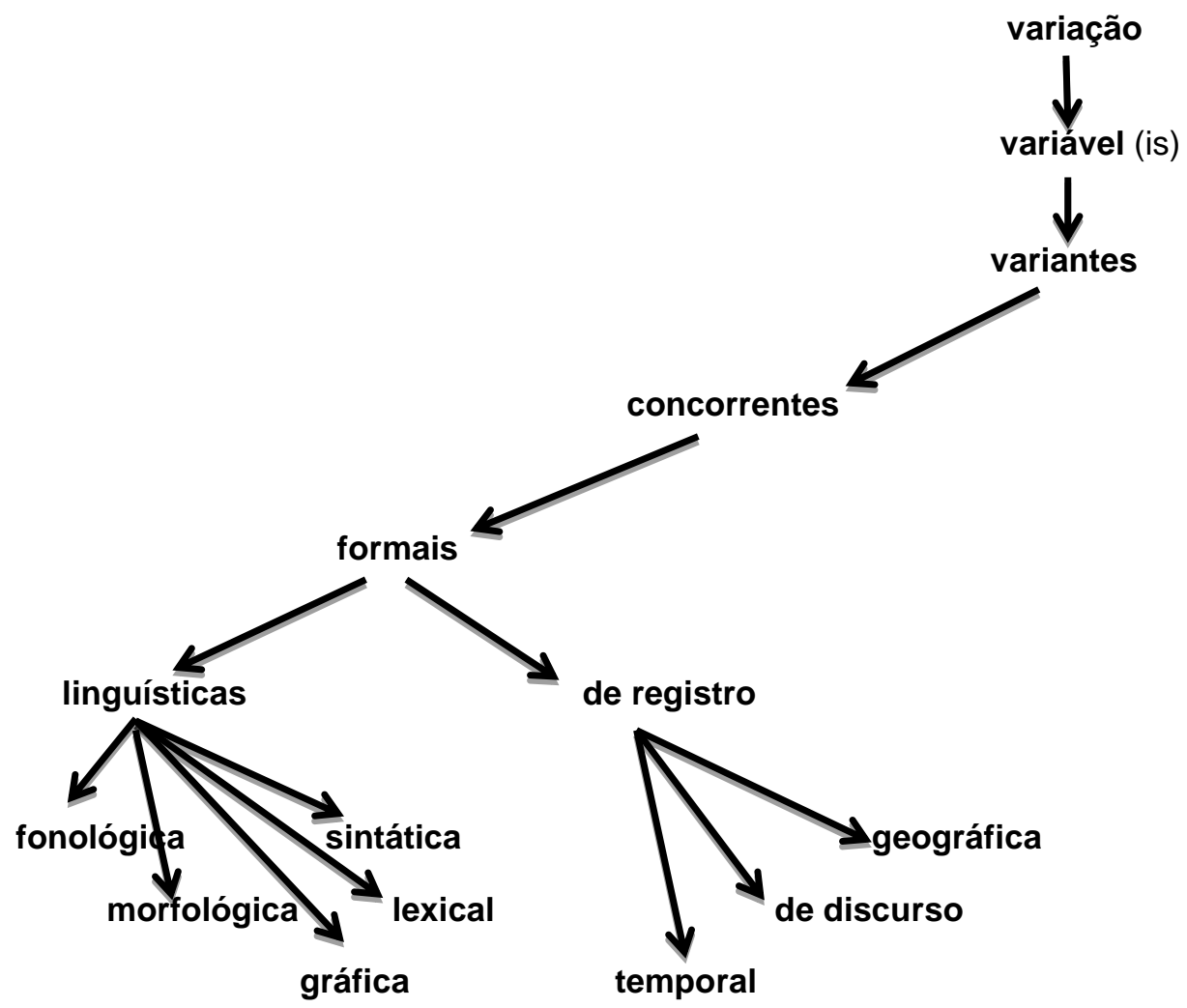

\subsection{Propriedades e Concepções do termo}

O termo é reconhecido por unanimidade entre os pesquisadores por unidade lexical especializada. Essas unidades são elementos que formam 0 conjunto conhecido por terminologia. A terminologia possui um caráter científico, técnico e tecnológico.

Para Krieger (2000, p. 62) o termo é uma unidade lexical básica da Terminologia, trata-se de uma entidade complexa, cujo reconhecimento consiste numa das mais difíceis tarefas do trabalho terminográfico. Consequentemente, é um dos pontos nevrálgicos das aplicações terminográficas, estudos teóricos da Terminologia. Entender o termo é de certa forma, entender o sentido maior dessa área de conhecimento. 
A terminologia na representação do conhecimento com base em Benveniste (apud Krieger 2001, p. 66) marca,

\begin{abstract}
em toda ciência o advento ou desenvolvimento de uma contextualização nova, assinalando, assim, um momento decisivo de sua história. Poder-se-ia mesmo dizer que a história particular de uma ciência se resuma na de seus termos específicos. Uma ciência só começa a existir ou consegues se impor na medida em que faz existir e em que impõe seus conceitos, através de sua denominação. Ela não tem outro meio de estabelecer sua legitimidade senão por especificar seu objeto denominando-o, podendo este constituir uma ordem de fenômenos, um domínio novo ou um modo novo de relação entre certos dados. O aparelhamento mental consiste, em primeiro lugar, de um inventário de termos que arrolam, configuram ou analisam a realidade. Denominar, isto é, criar um conceito, é, ao mesmo tempo, a primeira e última operação de uma ciência (1989, p. 252).
\end{abstract}

Conhecidas por comunicações especializadas, os termos se apresentam nos textos das diferentes áreas, e também nos diferentes discursos de especialistas. É fundamental para a formação da exatidão de conceitos do saber científico e tecnológico. Para Krieger (2001, p.67)

Tal precisão é uma condição necessária a um eficiente intercâmbio comunicacional entre especialista dos diferentes ramos do conhecimento. Assim, a busca de univocidade explica o uso recorrente das terminologias nas linguagens especializadas. Isso deve - se, em muito, ao próprio caráter dos termos, considerados como ideias de expressão de monorreferencialidade, de monossemia e de exclusividade denominativa.

É evidente que a terminologia tem um papel essencial para a comunicação de áreas específicas do conhecimento. Cabré (2010, p. 365) descreve a terminologia como sendo um conjunto do léxico de especialidade,

entendida como conjunto del léxico de las especialidades, no se há mantenido ajena a este sueño sino que, al contrario, lo há radicalizado por motivos básicamnete funcionales. La necessidade de dispor de normas em terminoligía nace de la preocupación ante la multiplicación y la diversificación del conocimiento técnico así omo de la búsqueda de formas comunicativas que aseguren la transferência de conocimientos, servicios y produtos.

A origem dessas preocupações, para a pesquisadora, veio todas por meio da história da Revolução Industrial. 
El nuevo contexto erigido por la revolución industrial reclamaba, en el plano de la creación de recursos, el desarrollo a gran escala de la terminología de todos los domínios técnicos; pero también, en el ámbito de la comunicación, la fiabilidade de los intercâmbios comunicativos a nível internacional. Para esto era necessária no sólo la elaboración de terminología em cada lengua, sino además la validación de las correspondências terminológicas entre las diferentes lenguas. Sólo así se podría assegurar uma comunicación interlinguística fiable (CABRÉ, 2001, p. 366).

Os cientistas há muito tempo haviam adotado um modelo para assegurar a univocidade de seus intercâmbios comunicativos, de acordo com a origem de uma nomenclatura científica independente das línguas reais. Uma elaboração única de terminologia para todas as línguas era considerada importante, pois manteria uma maior fidelidade na comunicação técnica entre os países de línguas diferentes.

De acordo com Finatto (2001, p.152), quando pensamos em comunicação profissional especializada através do ideal de univocidade, baseada na teoria terminológica tradicional, segundo o qual "a cada termo deve corresponder apenas um conceito", temos a ideia de que a comunicação não é infectada por sentidos duplos, imprecisões, da língua comum.

Nesse sentido, se tomássemos como exemplo a Química, poderíamos dizer que ao termo ácido corresponde um conceito única e inequivocamente estabelecido. Contudo, nessa mesma área de especialidade, se pensarmos na realidade linguística circunscrita por Brasil e Portugal, verificaríamos que ao termo brasileiro ácido nítrico corresponde o português ácido azótico. A relação estabelecida entre essas duas denominações oriundas de duas variantes de um mesmo sistema linguístico, numa mesma área de conhecimento, seria a de sinonímia? Paradoxalmente, ao menos em tese, no âmbito dos estudos teóricos tradicionais, não deveria haver espaço para a sinonímia numa linguagem de especialidade. (Finatto 2001, p.152)

Para concluirmos comungamos do pensamento de Cruz (2005, p.57) quando diz que "a dimensão conceitual do universo terminológico responde fortemente pelas interpretações de que um termo é, antes de uma unidade linguística, uma unidade de conhecimento, cujo valor define-se pelo lugar que ocupa na estrutura conceitual de especialidade".

Adotamos então para a pesquisa, uma metodologia relacionada à socioterminologia, envolvendo a escolha das áreas específicas; delimitação de 
corpus; adoção de critérios e categorias que estão descritos no próximo capítulo. 


\section{METODOLOGIA}

Para o propósito da pesquisa, foi utilizado como critérios de seleção de dados, a escolha de termos que eram utilizados em contextos diversos como em sala de aula por professores da área técnica, pelos técnicos na hora da assistência e pelos agropecuaristas em situações habituais de uso. Adotamos inicialmente, algumas posturas metodológicas previstas por Faulstich (1995) para o trabalho socioterminológico, a saber:

a. a escolha de áreas específicas para a organização do corpus do trabalho;

b. a delimitação do corpus;

c. a adoção de critérios e categorias para a análise do tipo de variação apresentada pelas unidades selecionadas.

Para análise das unidades terminológicas coletadas, seguimos os fundamentos teóricos de Faulstich (1995-2003), posto que o referido trabalho pretende interpretar o constructo teórico elaborado pela autora acerca da variação terminológica.

Cruz (2009, p. 59-74) comenta que o foco funcionalista possibilita não só uma análise dos termos sob o ponto de vista lexical e conceitual, mas também o estudo dos fatores de influência na sua forma e função que vão além das características morfossintáticas e conceituais. Além disso, fornece importantes subsídios para explicar a produtividade e a variação entre termos simples e predicados nas unidades terminológicas nos textos.

Notamos nesta pesquisa, que a variação terminológica da Agropecuária, colabora com os estudos mais recentes sobre terminologia, porque considera os termos entidades variantes, por fazer parte de contextos distintos e funcionar nas variações mais diversificadas da(s) língua(s). A ideia de que o termo é uma denominação unívoca vai ficando em desuso e um modelo de análise possível é o que parte do funcionalismo, que fornece a criação de categorias e de tipos de variantes terminológicas em consonância com os usos, de acordo com Faulstich (2001, p.11-40). Além de analisar o papel do técnico entre os léxicos na hora da assistência ao homem do campo. 


\subsection{Fonte de Dados}

Para a recolha da fonte dos dados, estudamos com os alunos do curso, por meio de aulas expositivas e pesquisas, o processo de variação da linguagem de especialidades da Agropecuária, na forma como são registrados, com o intuito de extrair o léxico específico como dados para análise. Portanto utilizamos as fontes descritas abaixo:

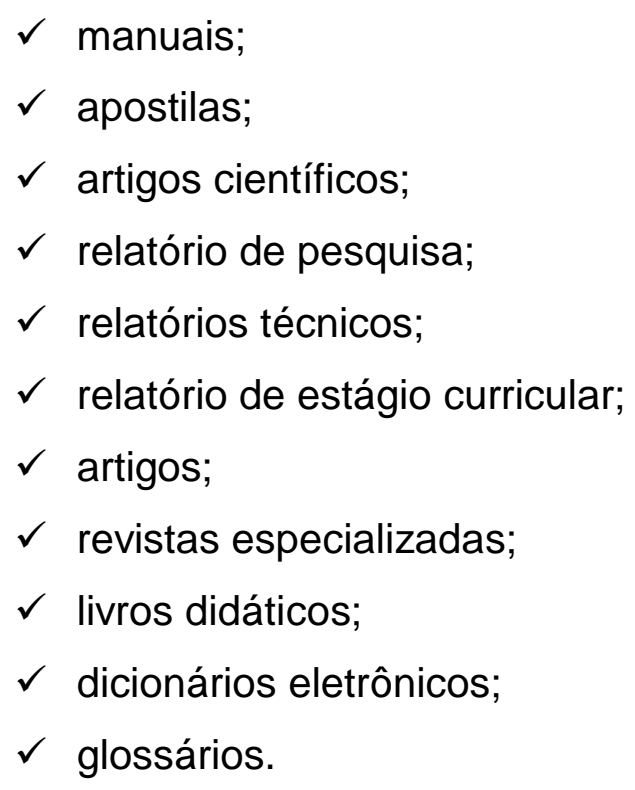

Os textos analisados estavam em formato impresso e em formato eletrônico no acervo da biblioteca do campus e no laboratório de informática. As subáreas pesquisadas foram: Avicultura, Apicultura, Bovinocultura, Suinocultura e Horticultura. Foram escolhidas por se destacarem como as mais cultivadas pelos agropecuaristas da microrregião estudada.

Como fonte de dados, também foram utilizadas entrevistas feitas com agropecuaristas de dois Projetos de Assentamentos - PA, Nova Esperança e o Natal, por meio de questionários. Tendo como objetivo, recolher termos comuns das subáreas analisadas.

Para pesquisarmos sobre o papel do técnico de Agropecuária, utilizouse o Projeto Pedagógico de Curso- PPC do campus e Relatórios de Estágio Curricular elaborado pelos alunos das turmas de 2015. 
Para a construção desse estudo, frisamos, mais uma vez o quanto é necessário conhecer e analisar o léxico com vista a buscar explicar a importância da atuação do técnico de acordo com a missão educativa do IFTO (2009), que tem como objetivo:

preparar indivíduos para o exercício da cidadania, promover consciência social, formar e qualificar técnicos competentes e atuantes na sociedade, contribuindo dessa forma para o desenvolvimento e crescimento humano, e para a melhoria da qualidade de vida das pessoas.

Inicialmente, foram realizadas aulas expositivas sobre variação linguística pela pesquisadora, que também é a professora da disciplina de Língua Portuguesa dos 140 alunos das $3^{\text {a }}$ séries do ano de 2015. O objetivo desejado foi de levantar questionamentos como: O que é variação linguística? Onde podemos encontrar essas variações? O que é preconceito linguístico? $\mathrm{O}$ que é preconceito social?

As respostas dos alunos serviram de investigação para descobrir a noção deles sobre as variedades que ocorrem na língua de especialidade e do papel como técnicos ao assistirem os agropecuaristas. Após o primeiro momento, foi feito uma leitura em dupla de dois poemas: 'Vício na Fala', do intelectual e poeta brasileiro, Oswald de Andrade e o 'O Poeta da Roça', do autor 'Patativa do Assaré',

\section{Vício na Fala}

Para dizerem milho dizem mio

Para melhor dizem mió

Para pior pió

Para telha dizem teia

Para telhado dizem teia

E vão fazendo telhados. (Oswald de Andrade )

Apresentamos o poema 'Vício na Fala' do dramaturgo brasileiro, consagrado escritor, Oswald Andrade, que mostrou a pronúncia encurtada de algumas palavras pelos seus falantes. Para o autor, os falantes que dizem 'mió', 'pió', 'teiado', criam novas formas de pronúncia que se sobressai em alguns casos da norma culta. Vimos com isso, os transtornos entre "língua $x$ fala" vivenciados pelos falantes. Discutimos em seguida o poema: 


\section{O Poeta da Roça}

Sou fio das mata, cantô da mão grossa, Trabaio na roça, de inverno e de estio A minha chupana é tapada de barro Só fumo cigarro de paia de mio.

Sou poeta das brenha, não faço pape De argum menestré, ou errante canto Que veve vagando, com sua viola, Cantando, pachola, à procura de amo.

$\mathrm{Na}$ tenho sabença, pois nunca estudei, Apenas eu sei o nome assina.

Meu pai, coitadinho! Vivia sem cobre, E o fio do pobre não pode estuda.

Meu verso rastêro, singelo e sem graça, Não entra na praça, no rico salão, Meu só entra no campo e na roça, Nas pobre paioça, da serra ao sertão[...]

(Patativa do Assaré)

Nesse poema, pudemos identificar a fala típica do brasileiro do meio rural, por meio da pronúncia de algumas palavras do texto, entre elas, 'cantô', 'Trabaio', 'chupana', 'argum', 'menestré', 'veve', 'rastêro', 'paioça'.

O objetivo de analisarmos o poema seria a percepção dos alunos de fatores determinantes à forma de expressão do texto. Como exemplo: fatores geográficos, históricos, sociológicos, ideológicos e fatores contextuais.

Foram propostas questões a serem realizadas pelos alunos, como: Quais são as variedades linguísticas encontradas nos poemas? Após a leitura, identifique de qual região o vocabulário é semelhante? Rural ou urbano? Nas cidades é possível percebermos estas variantes?

Os alunos redigiram todas as variedades encontradas nos poemas, e as passaram para a norma padrão e, após discutirem as respostas, foi averiguado se algumas delas coincidiram. Em seguida, discutimos sobre o 'preconceito linguístico', de acordo com Scherre (2013), onde a autora cita que

O preconceito linguístico - o mais sutil de todos eles - atinge um dos mais nobres legados do homem, que é o domínio de uma 
língua. Exercer isso é retirar o direito de fala de milhares de pessoas que se exprimem em formas sem prestígio social. Não quero dizer com isso que não temos o direito de gostar mais, ou menos, do falar de uma região ou de outra, do falar de um grupo social ou de outro. $O$ que afirmo e até enfatizo é que ninguém tem o direito de humilhar o outro pela forma de falar. Ninguém tem o direito de exercer assédio linguístico. Ninguém tem o direito de causar constrangimento ao seu semelhante pela forma de falar.

O preconceito linguístico é caracterizado pela autora como um julgamento depreciativo, desrespeitoso, jocoso e, consequentemente, humilhante da fala do outro ou da própria fala, e que tem como alvo os grupos com menor prestígio social.

Faulstich (2008) argumenta sobre as transformações que a Língua Portuguesa sofreu, suas variedades, normas de uso e o preconceito social.

a língua portuguesa, para chegar à língua de hoje, passou por inúmeras variações no tempo e no espaço e criou variedades e, por conseguinte, as diversas normas de uso. Esses modos normais de falar convergiam para um modelo, que se fazia necessário, como um padrão da língua, se fosse 'adulterado' ou a variedade voltava a ser entendida como tal, ou era entendida como erro de uso segundo a consistência da época. O padrão - estrutura abstrata a ser seguida, que nada mais era do que uma norma - passou a ter o papel político forte na criação do estado nacional. Como era preciso navegar, era preciso também que os fatos, vistos no novo mundo, fossem registrados, escritos; para escrever, era preciso haver minimamente uma unidade. Era o social falando mais alto que o linguístico. E, como se percebe, a língua em si nada tinha a ver com isso.

Ainda para a pesquisadora, já desde épocas primitivas, era possível constatar que, no decorrer do tempo, a variação acentuada, primordialmente a grafia, enquanto a estrutura da língua, cada vez mais fiel a uma forma de escrever, servia de modelo para os aprendizes.

Baseado no pensamento dos autores pesquisados, discutimos a existência de variedades linguísticas, que podem ser utilizadas em contextos diversos da fala, porém é necessário conhecer a sistematização 
da língua, por ela ser necessária em situações sociais que exigem mais formalidade.

Como instrumento pedagógico, realizamos um seminário, em que os alunos puderam discutir sobre o assunto após terem pesquisado em outras fontes. Com isso, abrimos um espaço para o debate sobre o papel deles como técnico em meio às variantes na língua de especialidades. Estas estratégias metodológicas desencadearam uma análise do léxico especializado e do léxico comum, no momento da assistência. Após isso, foram dividas as turmas em grupos, para pesquisar textos técnicos utilizados pelos professores.

Foram criadas, com base na análise dos textos colhidos, cinco listas, as quais possuíam alguns termos mais usados que compunham o léxico especializado das subáreas estudadas, em sequência os alunos acrescentaram a essas listas, o léxico comum desses termos conhecidos por eles. A maior colaboração, na descrição do léxico comum, foi por parte dos alunos oriundos da zona rural, filhos e netos de agropecuaristas, e por alunos que já tinham estagiado em fazendas, e em lojas de produtos agropecuários, bem como em empresas atuantes na elaboração do Programa Nacional de Agricultura Familiar - PRONAF, Programa Nacional de Apoio ao Médio Produtor - PRONAMP e o Cadastro Ambiental Rural - CAR.

Formulamos, cuidadosamente, cinco questionários de pesquisa a fim de entrevistarmos os agropecuaristas, com o intuito de investigarmos o léxico comum, das subáreas em questão. A organização das perguntas se deu a partir de conceitos extraídos de textos utilizados pelos professores da área técnica. Esses questionários foram construídos com perguntas abertas e fechadas em formato conceito - figura, seguidas de variantes disponibilizadas em alternativas. Cada pergunta foi ilustrada com uma figura para contribuir na compreensão das questões pelos trabalhadores do campo.

As entrevistas tiveram como fonte indivíduos nascidos na microrregião do Bico do Papagaio, ou aqueles que residiram na mesma, desde cinco anos de idade, produtores das culturas das subáreas estudadas, formando células de dados com o mesmo número de informantes. 


\subsection{Critérios para recolha e organização dos dados}

O intuito dessa pesquisa é investigar como as variações acorrem e em que contexto aparecem, a fim de contribuir para a discussão da adequação do ensino da Língua Portuguesa no curso técnico em Agropecuária e, consequentemente, discutir qual é o papel do técnico entre os léxicos da área, tanto de especialidades quanto comum no momento da assistência aos produtores rurais.

O resultado da pesquisa é a produção de um glossário das subáreas pesquisadas na microrregião do Bico do Papagaio, para subsidiar alunos, egressos e professores.

\subsection{Plano para coleta de dados}

$\mathrm{Na}$ coleta de dados houve a recolha do léxico especializado em textos da área técnica, utilizados pelos professores do curso, como já mencionamos anteriormente. A recolha do léxico comum foi realizado por meio de entrevistas. Após a coleta, elaboramos listas contendo os léxicos coletados e os analisamos com base no constructo de Faulstich (1995).

\subsubsection{Entrevistas}

As entrevistas foram necessárias para a coleta do léxico comum das subáreas estudadas. Obedecemos a uma sequência, desde a elaboração dos questionários até a aplicação dos mesmos, como:

a) elaboração prévia do instrumento de pesquisa.

b) aplicação de 10 questionários de cada Subárea (Avicultura, Apicultura, Bovinocultura, Horticultura e Suinocultura) nos Projetos de Assentamento Nova Esperança e Natal.

c) aplicação de 20 questionários com agropecuaristas produtores das subáreas investigadas, nascidos e criados na microrregião do Bico do Papagaio, ou aqueles que vivem desde 5 anos de idade naquela região.

d) a aplicação dos questionários por quatro alunos das $3^{\underline{a}}$ séries do curso, dois rapazes e duas moças, que foram previamente orientados à abordagem dos entrevistados. Dois alunos residentes em assentamentos, um da zona rural e outro da cidade. 
Segundo Miguel (2010) a entrevista, nas suas diversas aplicações, "é uma técnica de interação social, interpenetração informativa, capaz de quebrar isolamentos grupais, individuais e sociais, podendo também servir à pluralização de vozes e à distribuição democrática da informação". Tendo por base esta afirmação, a entrevista foi um instrumento de pesquisa fundamental para a investigação. Os alunos foram orientados ainda dentro do pensamento do autor, quando descreve em sua fala, qual postura o entrevistador deve tomar, quando o mesmo ratifica que,

\begin{abstract}
É importante, durante uma entrevista, que o entrevistador inicie suas perguntas de maneira ampla, não diretiva e que conduza as falas dos entrevistados, procurando pedir esclarecimentos ao que não foi compreendido e detalhes concretos aos exemplos dados. Ao fazer uma pergunta em aberto - não presumindo determinada resposta - o pesquisador estabelece um território a ser explorado, permitindo que o participante a tome da maneira que desejar. Por outro lado, não deve perder de vista a finalidade e o foco da entrevista, pré-ajustando e redirecionando a conversa quando achar necessário. 0 trabalho básico do entrevistador é escutar ativamente, auxiliando a construção de significados dos participantes e promovendo o andamento da entrevista.
\end{abstract}

A utilização dos questionários foi feita com cautela, a fim de evitar questões excessivas ou esquecidas. Para Richardson (1999, p. 202), "esta etapa refere-se à aplicação prévia do questionário a um grupo que apresente as mesmas características da população incluída na pesquisa", pois, segundo o autor, objetiva revisar e direcionar os aspectos da investigação. O entrevistador deve ter um rigor técnico com os pesquisados na hora do contato.

\title{
5.4 Seleção e organização dos dados:
}

Selecionamos textos da área técnica de diversas fontes para análise dentro das subáreas estudadas, com o objetivo da recolha de dados de todas as fontes selecionadas. Após a análise foram formuladas listas descrevendo $o$ léxico de especialidade extraído dos textos analisados para verificação da presença de variantes na área, dentro do constructo proposto por Faulstich (1995-2003) como se afirmou anteriormente, e para isso foram adotadas algumas questões metodológicas: i) que os termos fossem unidades nominais e ii) que a variante pudesse ser classificada segundo o modelo adotado. 
Para averiguação de qual seria o papel do técnico dentro das subáreas analisadas, investigou-se os referidos documentos:

1. Referenciais Curriculares da Educação Profissional de Nível Técnico na área profissional da Agropecuária (2000, p.19) onde afirma que,

O trabalhador necessita ser flexível, ou seja, saber lidar com uma variedade de funções, saber integrar-se a diferentes formas de agregação e mobilização de trabalhos, em que se tornem relevantes os atributos da abertura, responsabilidade, assiduidade, disciplina, criatividade, motivação, iniciativa, vontade de aprender e buscar soluções, organização e equilíbrio. O novo conteúdo do trabalho exige um menor recurso às atividades sensório- concretas, à força física e aos atributos musculares. Requer, porém, um maior recurso as atividades de abstração, à capacidade analítica, necessária para lidar com operações que levem a transformação de símbolos em ações diferentes para leitura e interação com a realidade. Nesta perspectiva, a formação técnica profissional por competências, torna-se uma estratégia pedagógica inovadora, pois pressupõe que o desenvolvimento de mecanismos, cognitivos, sócio afetivos, psicomotores permitem que 0 trabalhador desenvolva as diversas habilidades polivalentes exigidas pelo mundo do trabalho, que garantem maior empregabilidade e um constante aprender a aprender.

2. Relatórios de Estágio Supervisionado (2015) como exemplo, temos o da aluna Júlia Cláudia Alves Rodrigues, que cumpriu seu estágio na empresa AgroAtins em 2015, nele ela descreve a necessidade de uma comunicação mais simplista e criteriosa, interativa e menos assimétrica do técnico para o homem do campo.

Atentei-me, que depois de uma explicação simples, porém criteriosa da parte do técnico sobre as formas atualmente usadas na pecuária ou na agricultura, os produtores, com uma vivência maior na área, se disponibilizaram a adaptar-se a tais métodos, mesmo sendo inovadores ou até mesmo desconhecidos, ou seja, quando existe por parte do técnico a mescla do uso no discurso do léxico especializado e o léxico comum, a comunicação é menos assimétrica e a interação flui. Além do mais, vi que a relação estabelecida entre técnicos e produtores é uma relação de troca de experiências de gerações diferentes, já que os agropecuaristas que nos procuraram foram senhores e senhoras com um tempo de experiência maior e escolaridade diferente, mesmo assim se disponibilizaram a receber informações novas de uma pessoa desconhecida, mais jovem e com pouco tempo de atuação no mercado de trabalho. Portanto, é interessante que o técnico, em respeito ao agropecuarista, tente utilizar um discurso mais 
perto da linguagem de uso, colaborando de forma mais efetiva com a produção dos Arranjos Produtivos Locais.

Após a análise de alguns relatórios de estágio curricular, percebemos a necessidade que os técnicos tinham em adaptar a linguagem técnica estudada no curso, na linguagem comum utilizada pelos produtores rurais da região pesquisada, preservando a cultura e historicidade desses trabalhadores. 


\section{ANÁLISE E DISCUSSÃO DOS DADOS}

Ao analisar o contexto da ocorrência da variação, com base no modelo de Faulstich (1995-2003), notamos que a teoria dá suporte necessário à investigação presente, uma vez que "as variantes são resultados dos diferentes usos que a comunidade, em sua diversidade social, linguística e geográfica, faz do termo" (FAULSTICH, 1995) tendo em vista que o processo de variação dentro do construto teórico tem as variáveis como produção de variantes, funcionando nas línguas de acordo com as funções que elas venham a ter na linguagem de especialidade ou na linguagem comum (FAULSTICH, 2002, p.77).

Dentre os tipos de variantes que ocorreram nos dados em análise há:

1. Variante terminológica morfológica, a que apresenta alternância de estrutura de ordem morfológica na constituição do termo, sem que o conceito se altere, como 'gado leiteiro' e 'gado de leite', a variação atua nos formantes do termo. Esta variação se processa na substituição de uma parte do item terminológico por outro. Assim, o adjetivo 'leiteiro' se expande no sintagma preposicionado 'de leite', formado de preposição + substantivo, ou ocorre o contrário, o sintagma preposicionado se reduz a um adjetivo. $O$ mesmo ocorre em 'ave de postura' e 'galinha poedeira', embora haja a substituição do termo 'ave' (hiperônimo) para 'galinha' (hipônimo).

2. Variante terminológica fonológica: a que a escrita pode surgir de formas decalcadas da fala, como em 'fel' em relação a 'feli', 'debulha' em relação a 'debuia', em que ocorre a variação marcada pela oralidade.

3. Variante terminológica gráfica: a que se apresenta sob a forma gráfica diversificada de acordo com as convenções da língua, como 'suã' e 'suam'. Neste tipo de variação, os termos 'suã' e 'suam' são diferençados na escrita pelo uso da marca e nasalização til ( ) no primeiro formativo, e, no segundo, pela presença do arquifonema nasal, registrado com ' $n$ '. Este tipo de variação decorre da forma escrita do termo.

Faulstich (2002, p. 73), observa que a variável, será realizada sob a forma de uma variante e estas podem pertencer a três polos: variantes concorrentes, variantes coocorrentes e variantes competitivas, esta última com apenas duas ocorrências nas subáreas pesquisadas. 
1. Variantes concorrentes: são aquelas que podem concorrer entre si, ou podem concorrer para a mudança. Nessa condição, uma variante que concorre com outra ao mesmo tempo não ocupa o mesmo espaço, por causa da própria natureza da concorrência. Tal ocorrência pode ser encontrada em 'vesícula melífera' e 'bolsa' e 'papo'. Onde na linguagem do especialista da área da apicultura, o termo 'vesícula melífera' irá ocorrer em oposição aos termos concorrentes 'bolsa' e 'papo', presentes na linguagem comum do trabalhador do campo. Esta variante é classificada por Faulstich (2002) como variante formal.

Neste tipo de variação, pudemos constatar que os termos coletados na pesquisa foram consideradas coocorrentes as seguintes unidades terminológicas:

Avicultura: galpão aviário/poleiro; galinha d'angola/capote; vesícula biliar/fel/feli; biogás/gás natural; campânula/aquecedor; aditivo/mistura; quebravento/lona; aditivo/mistura; círculo de proteção/separador; híbrido/ mistura de raça; frango de corte/frango de granja.

Apicultura: abelhas africanizadas/abelhas italianas; cera alveolada/cera prensada; fumigador/fumaceiro; néctar/mel da flor; operárias/obreiras; apitoxina/veneno; câmera de cria/ninho incubatório; cerificador solar/extrator; vesícula melífera/bolsa; alvado/porta; EPI(Equipamento de Proteção Individual)/vestimenta; predador/praga; glossa/língua; protetor de west/isolador de rainha; garfo desoperculador/pente.

Bovinocultura: manejo/tratamento; gestante/prenha; proteiro/piquete; invernada/pasto grande; vaca infértil/vaca manina; miíase/bicheira; esterco/adubo orgânico; coluna vertebral/espinhaço; cauda/rabo; helmintos/vermes; marrafa/topete; arisco/bravo; desmame/apartamento; abatedouro/matadouro.

Horticultura: policultivo/associação; erosão/voçoroca; agrovila/assentamento; debulha/debuia; canal/vala; sulco/leira; anomalia/defeito; matéria orgânica/esterco; leira/terra lavrada; apiloamento/aterramento; caule/talo; regador/molhador, bico de pato; pendúnculo/pendão; maturação/amadurecimento; solo/terra; patógenos/doenças. 
Suinocultura: cachaço/varão; castração/capação; baia/box; cio/viço; odor/fedor; constipação/prisão de ventre; lanternim/cumieira; monta/acasalamento; tetas/mamas; gordura/banha.

2. Variantes coocorrentes: são aquelas que têm duas ou mais denominações para um mesmo referente, como por exemplo, 'mistura' e 'suplemento'; 'separador' e 'protetor'; 'mistura de raça' e 'cruzamento'; 'frango de corte' e 'frango de granja'; 'piquete' e 'curral'; 'cruzamento' e 'cobertura'; 'mamas' e 'peitos'; 'gordura' e 'banha'. Esta variante é classificada por Faulstich (2002) como sinônimos, pois relacionam o sentido de dois ou mais termos com significados idênticos e podem coocorrer num mesmo contexto, sem que haja alteração no plano do conteúdo.

Neste tipo de variação, pudemos constatar que os termos coletados na pesquisa foram consideradas coocorrentes as seguintes unidades terminológicas:

Avicultura: poleiro/galinheiro; capote/angolista/tô fraco/guiné/cocar; fel/feli; aquecedor/esquentador; mistura/suplemento; Iona/cortina; mistura/suplemento; separador/protetor; mistura de raça/cruzamento.

Apicultura: abelhas italianas/oropa; fumaceiro/botador de fumaça; mel da flor/açúcar da flor; obreiras/trabalhadeiras; extrator/reciclador/derretedor; bolsa/papo; porta/entrada da caixa; vestimenta/capa grossa; praga/inimigo da abelha; língua/sugador/lambedor; protetor de realeira/isolador de rainha.

Bovinocultura: serviços/cuidados/tratamento; prenha/amojada; piquete/curral; pasto grande/pasto/quinta; vaca manina/fêmea refigo; estrume/adubo/bosta de gado; vermes/lombrigas; valente/bravo/brabo; apartamento/separação.

Olericultura/Horticultura: associação/roça misturada/consórcio/plantio junto; voçoroca/buraco; assentamento/P.A.(projeto de Assentamento)/povoado; vala/rego/buraco/valeta; linha/leira/fileira; defeito/aberração/doença/atrofiamento; estrume/esterco; aterramento/nivelamento/aterro; talo/galho; amadurecimento/floração; terra/chão/terreno; doenças/pragas. 
Suinocultura: barrão/varão; capação/amputação; box/chiqueiro; fedor/catinga; acasalamento/cruzamento/cobertura; mamas/peitos.

3. Variantes competitivas: são aquelas que relacionam significados entre itens lexicais de línguas diferentes, quer dizer, itens lexicais de uma língua $B$ preenchem lacunas de uma língua $A$, como no exemplo, 'protetor de west', em que o formativo estrangeiro 'west' precedido da preposição 'de' forma o sintagma preposicionado 'de west' e funciona como adjetivo de 'protetor'. O formativo 'protetor de west' compete com o formativo 'isolador de rainha'. O 'protetor de west' é um tipo de equipamento/instrumento em formato de funil que protege a rainha quando esta é inserida na colmeia.

O termo de origem estrangeira, 'Langstroth', compete com o formativo 'caixa padrão Langstroth' quando há o apagamento dos dois primeiros formativos e restando apenas a designação do nome do inventor da caixa. Isso ocorre pela lei do menor esforço da língua, em que há a preferência da designação do criador e não do formativo completo.

\subsection{Conclusão das análises}

A análise comprovou que há um grande número de variantes dos termos das cinco subáreas analisadas. Sendo que tanto as concorrentes quanto as coocorrentes se mostraram mais ativas no que se refere ao uso de uma ou outra variante, dependendo do grau de especialidade do falante/usuário.

As variantes foram do tipo gráfica, fonológica e morfológica levando sempre em consideração o tipo de formativo. Na gráfica registramos a ocorrência de 'suã' e 'suam', na morfológica, registramos os formativos 'gado de leite' e 'gado leiteiro' e, na fonológica, os termos 'fel' e 'feli'.

No grupo das concorrentes, registramos os termos da língua de especialidade em relação aos termos da língua comum, como por exemplo, biogás/gás natural; campânula/aquecedor; aditivo/mistura; círculo de proteção/separador; híbrido/ mistura de raça entre outros. Já no grupo das coocorrentes, estas foram originárias da língua comum, ou seja, a ocorrência dependia do grau de conhecimento do trabalhador do campo e mesmo em 
relação à região onde a variante ocorria, como por exemplo, capote/angolista/tô fraco/guiné/cocar todos relativos ao termo 'galinha d'Angola'.

No grupo das competitivas registramos apenas dois formativos, 'protetor de west' e 'caixa padrão Langstroth'.

As variantes registradas na pesquisa deram origem ao Glossário de Terminologias da Agropecuária e contribuirá para o trabalho junto aos assentados, trabalhadores do campo e os técnicos formados e em formação pelo IFTO - Campus Araguatins. 


\section{PRODUTO TÉCNICO - GLOSSÁRIO DE TERMINOLOGIAS DA AGROPECUÁRIA}

\subsection{Apresentação do Glossário}

Este glossário é parte integrante da dissertação de mestrado em Políticas Públicas e Gestão da Educação Profissional e Tecnológica pela UnB sob o título $O$ papel do técnico em Agropecuária: entre o léxico especializado e o léxico comum -, o qual foi gerado obedecendo a uma organização metodológica.

1. Identificação do usuário em potencial do glossário, os profissionais ligados à agropecuária: os apicultores, avicultores, bovinocultores, horticultores, suinocultores, técnicos, professores e estudantes da agropecuária entre outros interessados na área.

2. Registro das variantes das áreas pesquisadas.

3. Descrição do termo com base na formação: termo + conceito.

4. Consulta aos especialistas das diversas áreas pesquisadas. Contamos com

a colaboração de professores e estudantes do Curso Técnico Integrado ao Ensino Médio em Agropecuária do IFTO - Campus Araguatins.

5. Delimitação das cinco subáreas ligadas à agropecuária: aves de corte e postura, apicultura, avicultura, bovinocultura, horticultura e suinocultura.

6. Seleção das documentações bibliográficas, entre elas a entrevista pertinente às áreas selecionadas.

7. Organização das listas, dos conceitos e das figuras com vista ao registro da variação.

8. Redação do repertório terminológico sistêmico e em ordem alfabética, dividido em subáreas.

\subsection{Informação Técnica}

Apresentaremos os glossários das áreas da apicultura, da avicultura, da bovinocultura, da horticultura e da suinocultura: a entrada aparece em negrito, minúscula, em seguida, registramos a informação gramatical (classe e gênero), a definição da entrada, logo após, há a variante do termo-entrada, representada pela abreviatura var e a imagem do termo, quando houver. As 
remissivas são marcadas pela letra V. Em alguns casos, há a presença de Nota.

Estrutura do verbete

+entrada, +classe gramatical, +gênero, +definição, „variante, „remissiva, ınota, \pm figura.

\subsection{Glossário Terminológico da Agropecuária}

\subsection{1 - GLOSSÁRIO DE TERMINOLOGIAS DA APICULTURA}

abelha sem ferrão subst. f. Insetos, nativos do território brasileiro, que possuem o ferrão atrofiado. Var. meliponínea.
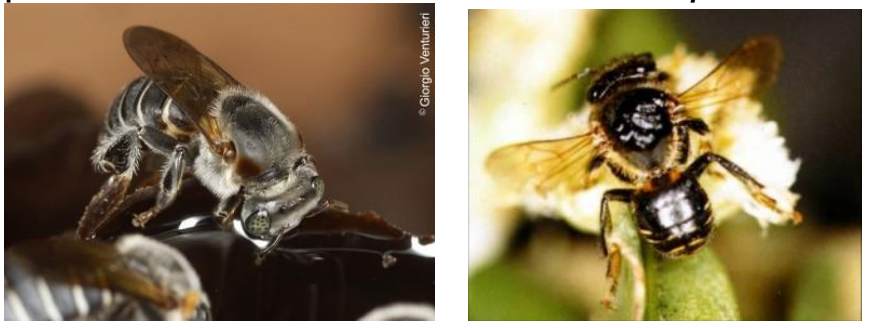

abelha africana subst. f. V. oropa.

abelha italiana subst. f. V. oropa.

acasalamento seletivo subst. $\mathrm{m}$. Seleção de zangões realizada pela rainha para reprodução e continuação da colmeia. Var. voo nupcial.

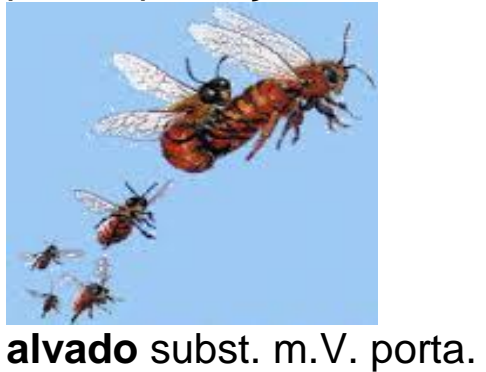

apartador de abelha subst. m. V. separador.

apiário subst. $\mathrm{m}$. Conjunto de colmeias, utilizadas para criação de abelhas, normalmente para a colheita de mel ou a polinização de culturas agrícolas. Var. cortiço.

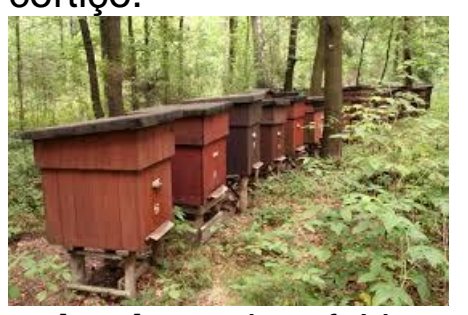

apitoxina subst. f. V. veneno. 
alvéolo subst. m. Célula responsável em armazenar o mel, o pólen, as crias e o própolis produzido pelas abelhas. Var. depósito.

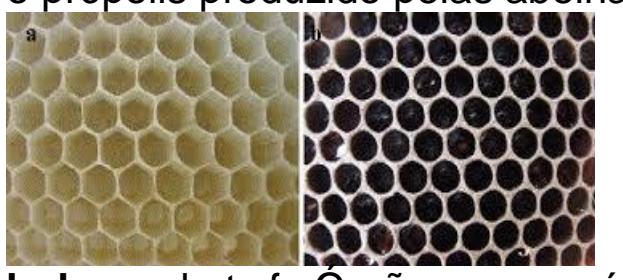

bolsa subst. f. Orgão responsável pelo transporte de néctar da flor para a colmeia. Var. vesícula melífera.

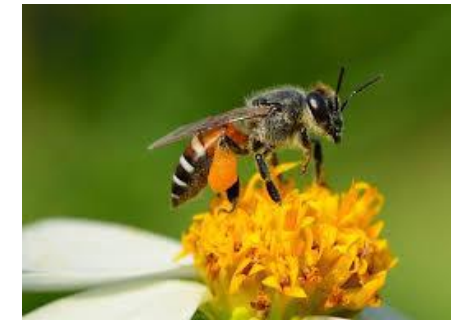

caixa móvel subst. f. V. colmeia.

caixa artificial subst. f. Caixa que substitui a colmeia e que facilita o manejo e criação de abelhas para o apicultor, permitindo maior organização do apiário e a produção de mel. Var. longstroth, padrão.

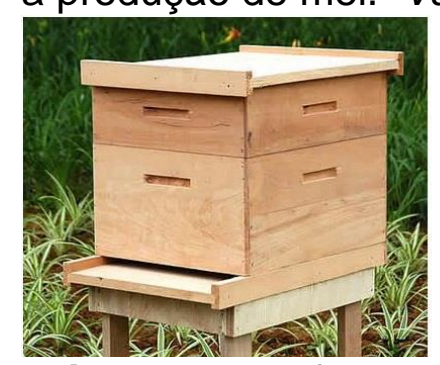

caixopa subst. f. V. colmeia.

canudo subst. m. V. língua.

câmera de cria subst. f. V. ninho.

cera prensada subst. f. Lâmina de cera de abelha prensada, que apresenta, de ambos os lados, o relevo de um hexágono do mesmo tamanho do alvéolo e serve de guia para a construção dos alvéolos dos favos. Var. cera alveolada.

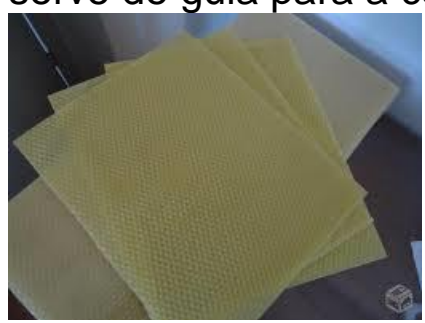

cera alveolada subst. f. V. cera prensada.

cerificador solar subst. m. V. extrator. 
colmeia subst. f. Lugar destinado a cria, produção de produtos naturais por meio das abelhas e reprodução de seres de sua mesma espécie, além de servir como morada. Var. caixa móvel, V. caixopa.

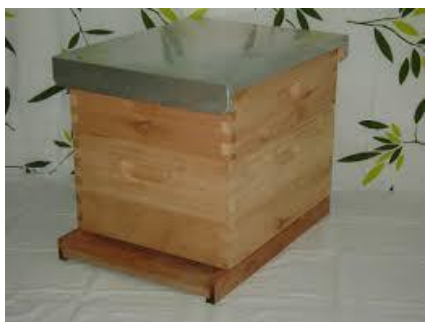

cortiço subst. m. V. apiário.

depósito de mel subst. $\mathrm{m}$. Estrutura construída de cera pela união dos alvéolos que as abelhas utilizam para o desenvolvimento das crias e armazenamento do alimento (mel e pólen). Var. favo.

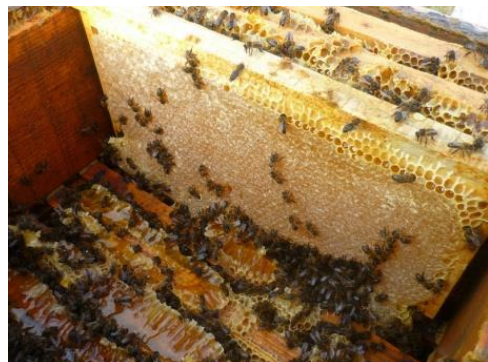

depósito subst. $m$. V. alvéolo.

doença subst. f. V. patologia, V. praga.

enfervilhamento subst. $m$. V. enxameação.

enxameação subst. f. Fenômeno natural de migração das abelhas, que pode ocorrer com parte dos indivíduos e a rainha ou todo o enxame. Var. enfervilhamento, V. fervilhamento.

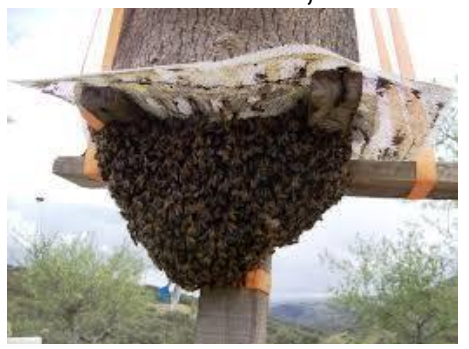

EPI subst. m. V. vestimenta.

esfriamento subst. m. Controle da temperatura interna da colmeia (entre $34 \mathrm{e}$ 35 graus Celsius). Var. termorregulação

esporão subst. m. V. ferrão.

extrator subst. m. Estrutura construída com materiais reciclados e serve para reaproveitar as ceras que seriam perdidas por meio de processo do material. Var. cerificador solar, V. reciclador.

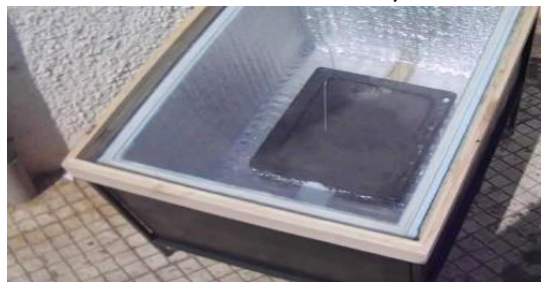

favo subst. m. V. depósito de mel.

fervilhamento subst. m. V. enxameção. 
ferrão subst. m. Arma de defesa das abelhas, por onde as excretadas uma toxina que, em grandes doses, pode ser fatal. Var. esporão.

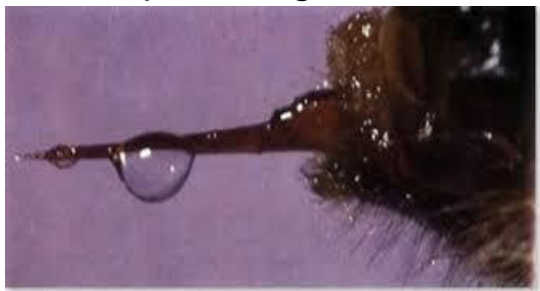

fumaceiro subst. m. Equipamento constituído de tampa, fole, fornalha, grelha e bico de pato que tem a função de produzir fumaça, sendo essencial para um manejo seguro dos apiários. Var. fumigador.

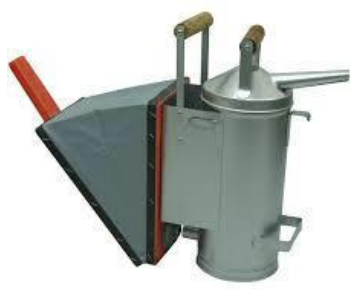

fumigador subst. m. V. fumaceiro.

garfo de soperculador subst. $\mathrm{m}$. V. pente.

glossa subst. f. V. língua.

isolador de ninho subst. $\mathrm{m}$. Equipamento que protege a realeira quando esta é introduzida na colmeia. Var. protetor de West.

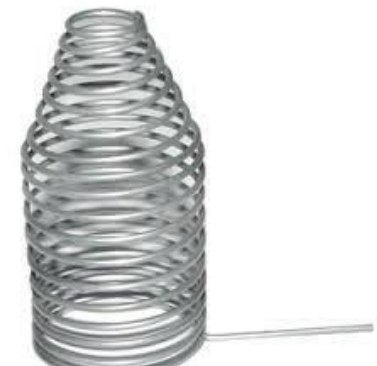

LANGSTROTH subst. f. V. caixa artificial.

língua subst. f. Órgão fino e comprido, responsável pela sucção de líquidos. Var. glossa, V. canudo.

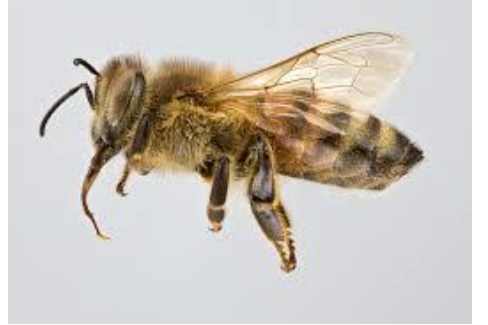

macacão subst. $m$. V. vestimenta.

meliponínea subst. f. V. abelha com ferrão.

mel da flor subst. $m$. $V$. néctar.

moldura subst. $f$. $V$. quadro. 
néctar subst. $\mathrm{m}$. Substância aquosa secretada pelos vegetais através de glândulas especializadas. Sua constituição química geralmente inclui açúcares em quantidades variáveis de acordo com a espécie. Var. Mel da flor.

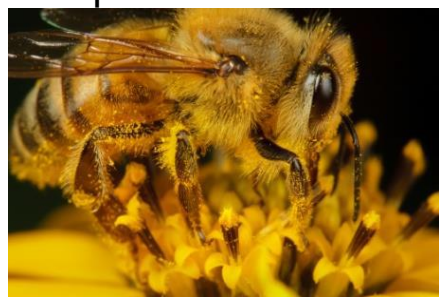

ninho subst. m. Parte da colmeia destinada a postura de ovos, reservada somente para reprodução por parte da rainha. Var. câmera de cria.

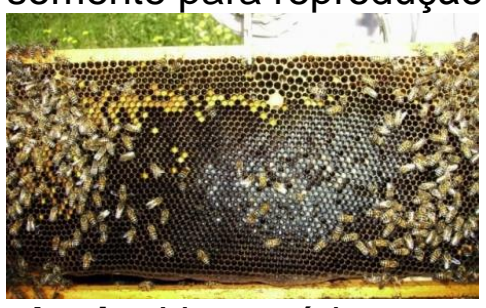

obreira V. operária.

ocelos subst. f. Estruturas pequenas e isoladas, constituídas pelo agrupamento de células fotorreceptoras, possuidoras de sensores e conectadas ao nervo óptico, também conhecido como olho primitivo das hidromedusas, platelmintos e alguns insetos. Var. olhos primitivos.

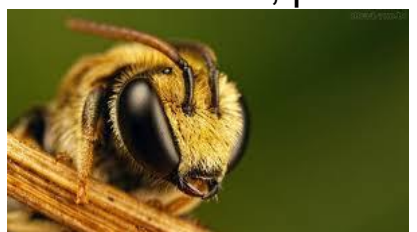

olhos primitivos subst. m. V. ocelos.

operária subst. f. Abelhas responsáveis por todo o trabalho dentro da colmeia. Var. obreira.

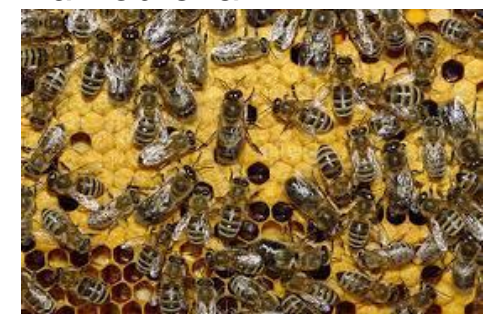

oropa subst. f. Políibridos resultantes dos cruzamentos entre as abelhasafricanas (Apis mellifera scutellata), e as raças europeias (Apis mellifera mellifera, Apis mellifera ligustica, Apis mellifera carnica, Apis mellifera caucásica), que foram introduzidas na América antes da chegada das africanas em1956, predominando, nestes políbridos, as características morfológicas e comportamentais das africanas. Var. abelhas africanas, V. abelhas italianas.

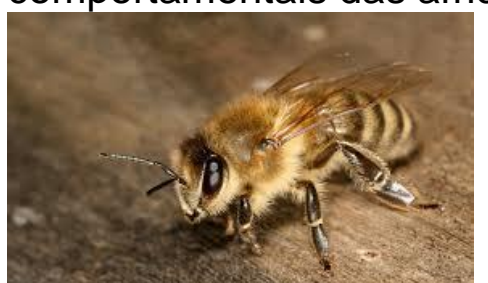

padrão subst. m. V. caixa artificial. 
patologia subst. f. Estudo das alterações estruturais, bioquímicas e funcionais nas células, tecidos e órgãos, que visa explicar os mecanismos pelos quais surgem os sinais e os sintomas de doenças. Var. praga, V. doença.

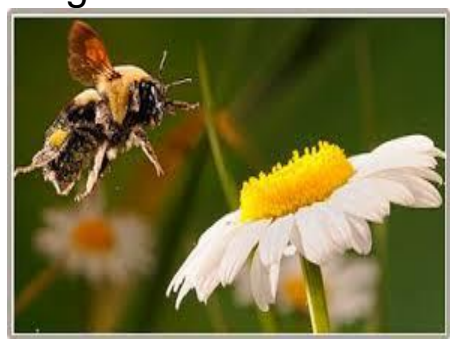

pente subst. $\mathrm{m}$. Instrumentos utilizado para a retirada do mel e pela extração do opérculo permitindo assim a saída do mel. Var. grafo desoperculador.

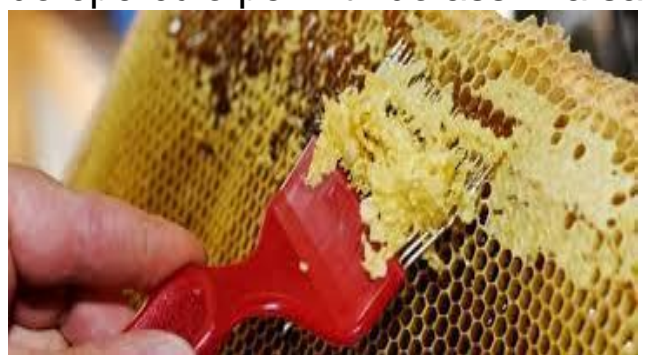

porta subst. f. Orifício de entrada das abelhas na caixa. Var. alvado.

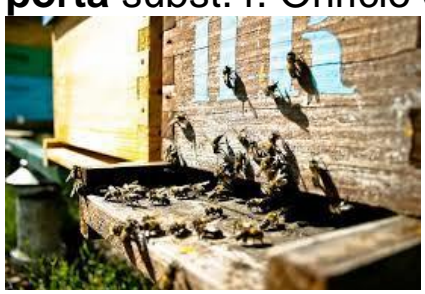

praga subst. f. V. patologia.

predador subst. m. invasor natural das colmeias em busca de alimentos. Var. praga.

protetor de West subst. $\mathrm{m}$. V. isolador de ninho.

quadro subst. m. Lâminas de ceras que precisam de sustentação para que os favos sejam uniformes e o apicultor tenha maior produtividade e rendimento do mel. Var. moldura.

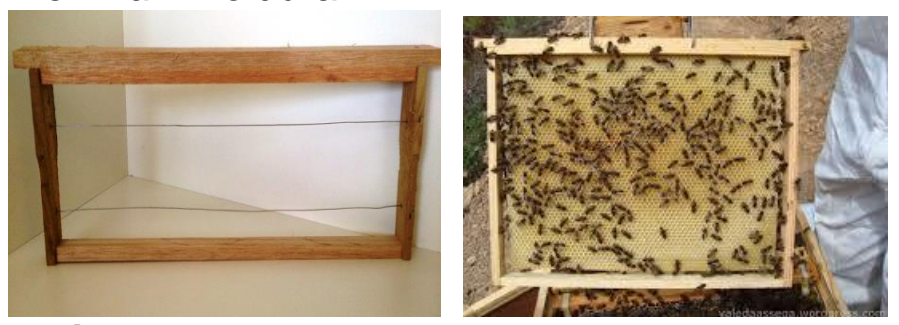

reciclador subst. $\mathrm{m}$. V. extrator.

roupa subst. f. V. vestimenta, macacão, EPI.

separador subst. m. Tipo de tela que serve para separa a melgueira do restante da colmeia, a fim de evitar o consumo do mel por parte dos zangões. Var. tela excluidora, V. apartadora de abelhas.

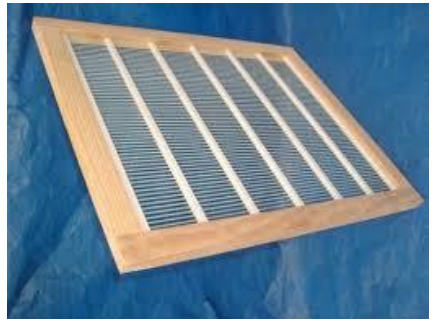


tela excluidora subst. f. V. separador.

termorregulação subst. f. V. esfriamento.

veneno subst. m. Substância excretada pelas abelhas para sua proteção. Var. apitoxina.

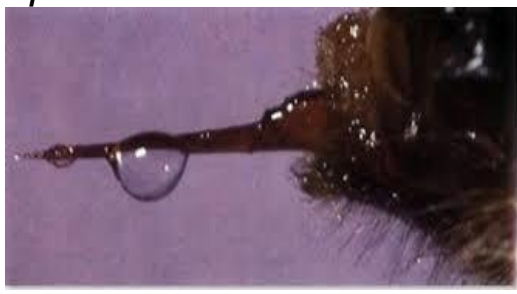

vesícula melífera subst. f. V. bolsa.

vestimenta subst. f. Equipamento de Proteção Individual constituído por macacão, botas, luvas e máscara protetora contra vespeiros. Var. roupa, V. macacão, V. EPI.

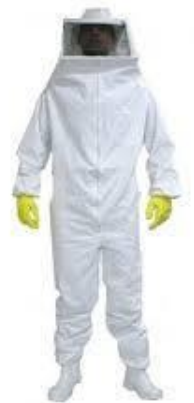

voo nupcial subst. m. V. acasalamento seletivo.

\subsection{2 - GLOSSÁRIO DE TERMINOLOGIAS DA AVICULTURA}

aditivo subst. m. Substâncias, adicionadas em pequenas quantidades na ração, para intensificar as propriedades desejáveis e (ou) eliminar as características indesejáveis da dieta das aves. Var. mistura.

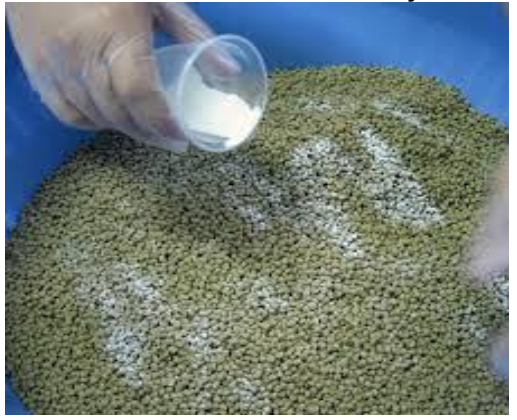

albumen subst. m. Nome dado a parte transparente da célula de ovo, que circunda a gema e é formada predominantemente por água e pela proteína albumina. Var. clara de ovo.

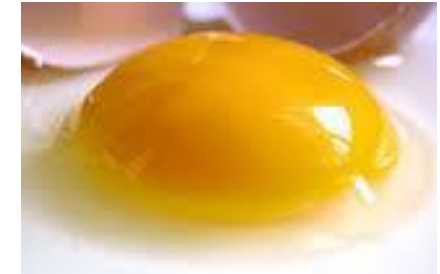

angolista subst. f. V. galinha d'angola.

aquecedor subst. m. V. campânula.

aquecedor de pinto subst. m. V. círculo de proteção.

aviário subst. $\mathrm{m}$. V. galinheiro, V. galpão viário. 
ave de postura subst. f. V. galinha poedeira.

biofertilizante subst. m. Resíduo do biodigestor, obtido da fermentação de materiais orgânicos como a vinhaça, as águas de lavagem de estábulos, baias e pocilgas. Var. adubo.

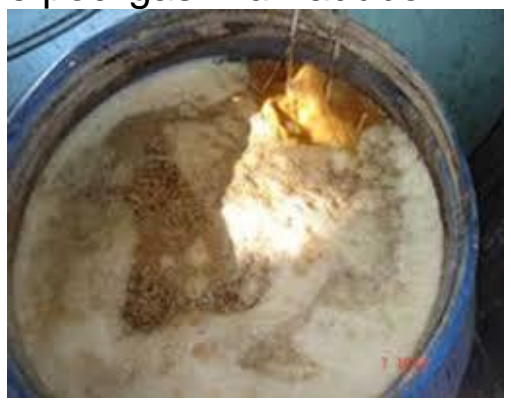

biogás subst. m. Produto da degradação anaeróbia da matéria orgânica, constituído principalmente de metano e gás carbônico. Var. gás natural.

cama de frango subst. $m$. V. maravalha.

campânula subst. f. Equipamento côncavo utilizado no aquecimento das aves.

Var. aquecedor.

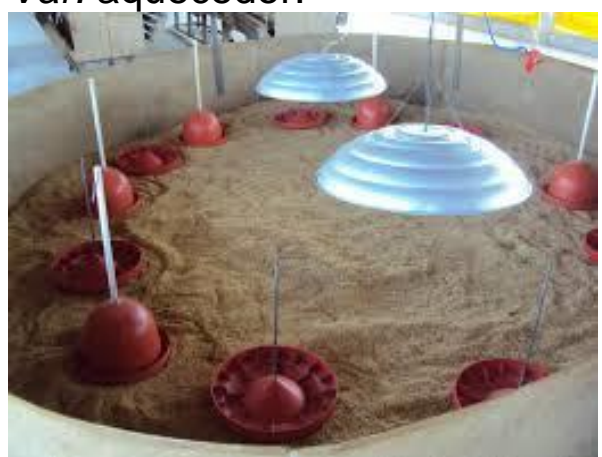

capote subst. f. V. galinha d'angola.

círculo de proteção subst. $\mathrm{m}$. Tipo de equipamento que tem como função proteger os pintos de correntes de ar e limitar a área disponível, mantendo-os mais próximos da fonte de aquecimento, água e ração. Var. separador, V. aquecedor de pinto.

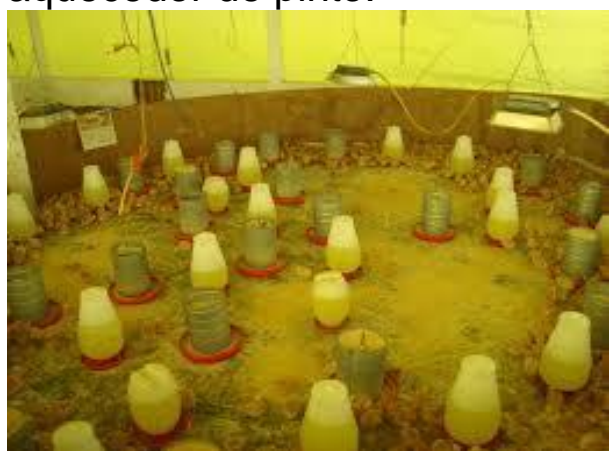

corta de bico subst. f. V. debicagem.

cortina subst. f. V. lona.

clara de ovo subst. f. V. albúmen.

coriza infecciosa subst. f. Tipo de corrimento ou fluído nas vias nasais, provocado por fungos ou bactérias, que afeta a produtividade do animal. Var. gôgo. 
debicagem subst. f. Prática que tem por objetivo melhorar o desempenho produtivo, reduzir o canibalismo, diminuir a bicagem de ovos e melhorar a conversão alimentar. Var. corta do bico.

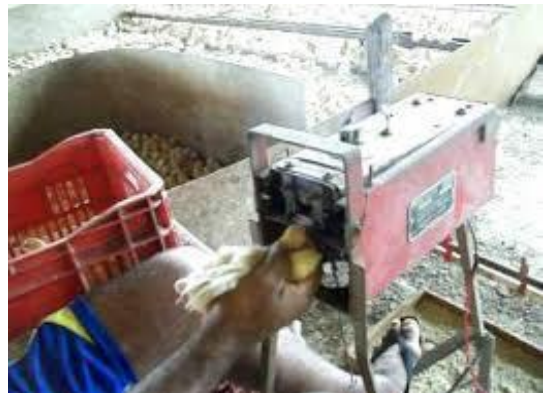

desinfecção subst. f. V. higienização.

fel subst. f. V. vesícula biliar.

feli subst. f. Var. vesícula biliar.

frango de granja subst. m. Tipo de animal, macho ou fêmea híbrido duplo (cruzamento de dois híbridos simples), resultante do cruzamento de galinhas de corte (matrizes) destinado à produção de carne com alto desempenho, abatido em idade jovem. Var. frango de corte.

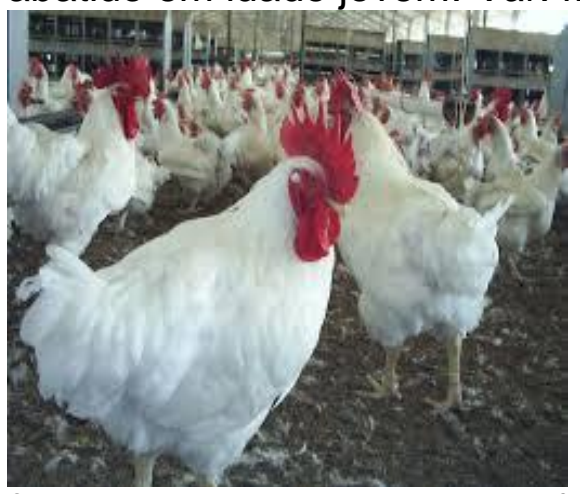

frango de corte subst. $m$. V. frango de granja.

galinheiro subst. $\mathrm{m}$. Construção constituída de cobertura de telha ou palha, desprovido de paredes laterais, utilizado para o abrigo e confinamento de aves. Var. galpão aviário, V. aviário.

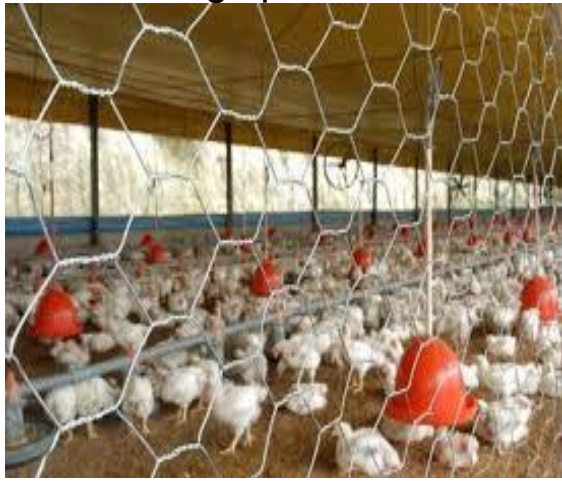

galpão viário subst. m. V. galinheiro, V. aviário. 
galinha poedeira subst. f. Tipo de ave confinada destinada à produção de ovos cuja qualidade é influenciada por fatores como condições de manejo, instalações, nutrição e ambiente. Var. ave de postura.

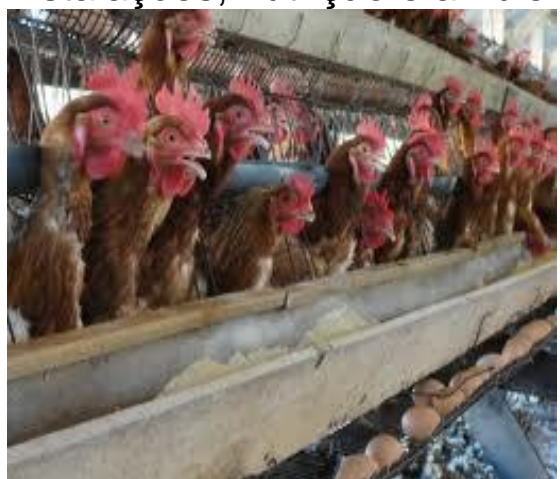

galinha d'angola subst. f. Ave que tem como característica a rusticidade e resistência, sendo de fácil manejo. Var. capote, angolista.

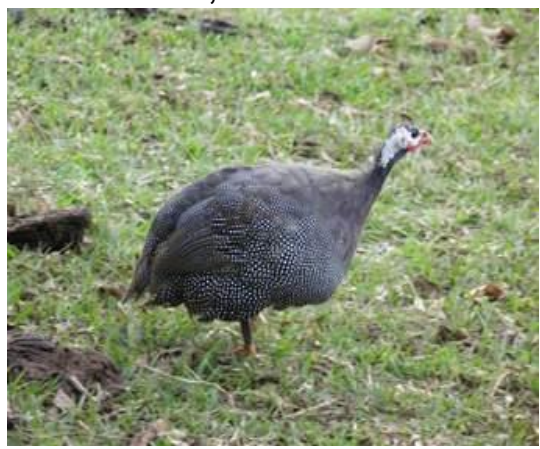

gás natural subst. m. biogás.

gôgo subst. m. V. coriza infecciosa.

híbrido subst. m. Indivíduo produzido pelo cruzamento de pais de dois genótipos diferentes. Var. mistura de raça.

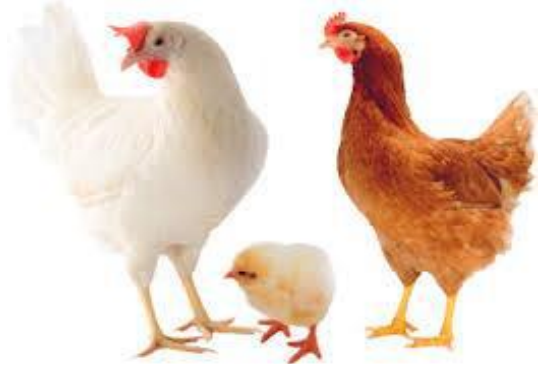

higienização subst. f. Ação de eliminar o risco de contágio por parte de agentes patogênicos a qual pode ser feita com meios físicos ou químicos. Var. desinfecção, V. limpeza.

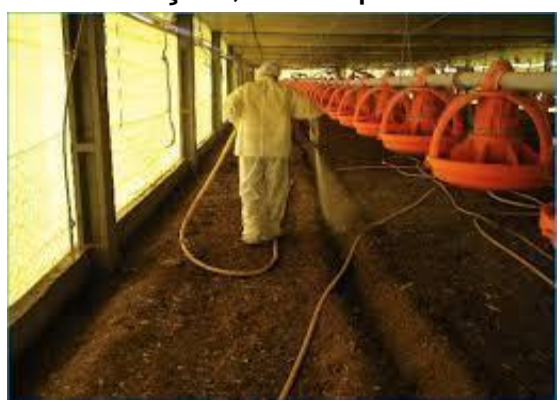

lanternim subst. m. Abertura na parte superior do telhado. Var. ventilação. limpador de calçados subst. m. V. pelúvio. 
lona subst. f. Material que deve ser instalado nas laterais, pelo lado de fora, para evitar penetração de sol, chuva e controlar a ventilação no interior do aviário. Var. cortina, V. quebra-vento.

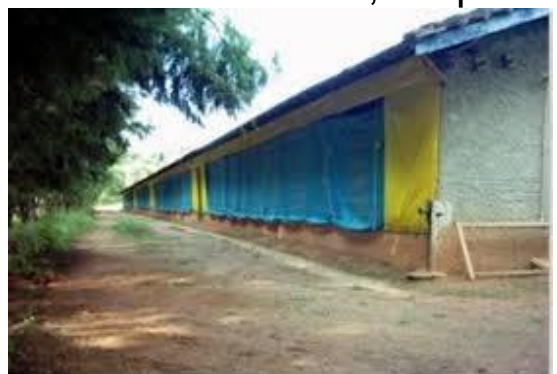

maravalha subst. f. Material distribuído em um aviário para servir de leito aos animais. Var. cama de frango, serragem.

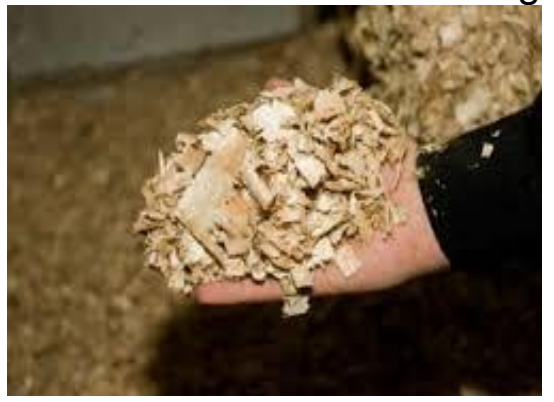

mistura subst. f. V. aditivo.

mistura de raça subst. f. V. híbrido.

pediluvio subst. $\mathrm{m}$. Recipiente com desinfetante para a desinfecção dos calçados, colocado na porta dos aviários. Var. limpador de calçados.

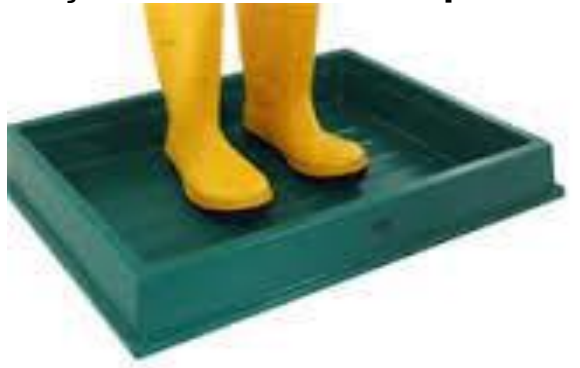

quebra-vento subst. m. V. lona.

separador subst. m. Círculo de proteção.

separação subst. f. V. seleção.

seleção subst. f. Método de escolha das matrizes, que tem por objetivo as melhores características de produção, seja ela de corte ou postura. Var. separação.

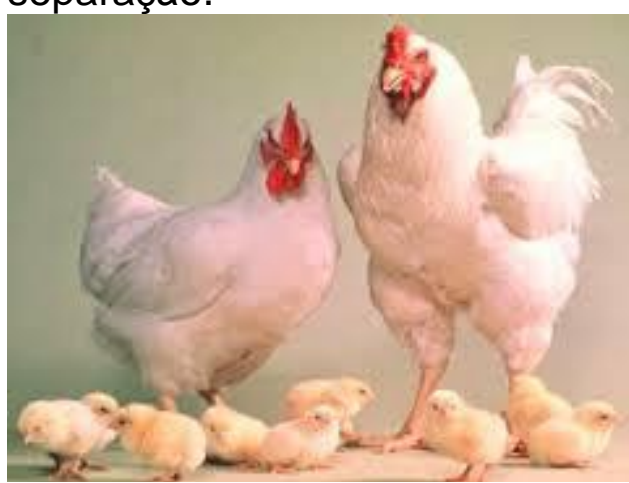

serragem subst. f. V. maravalha. ventilação subst. f. V. lanternim. 
vesícula biliar subst. f. Órgão muscular responsável pelo armazenamento da bile segregada pelo fígado. Var. fel, V. feli.

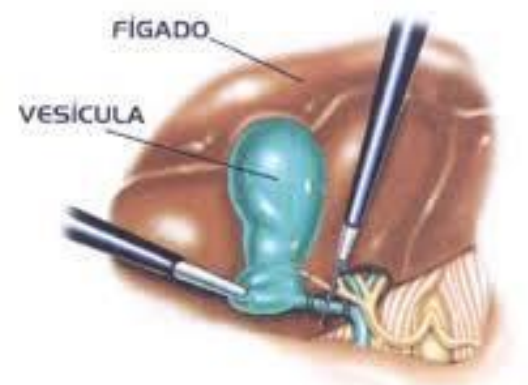

\subsection{3 - GLOSSÁRIO DE TERMINOLOGIAS DA BOVINOCULTURA}

abatedouro subst. $\mathrm{m}$. Espaço destinado ao abate animal e muitas vezes ao abate e processamento do abatido. Var. matadouro.

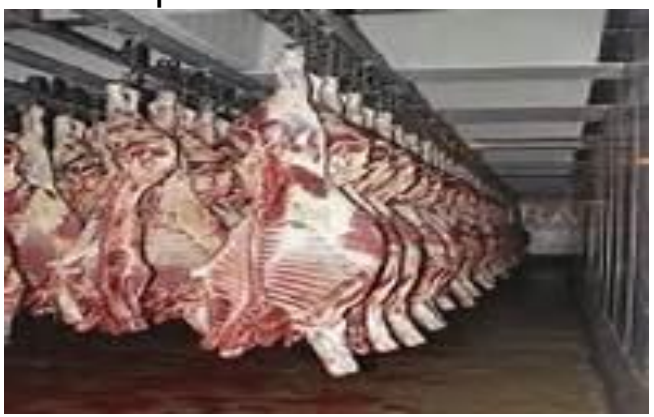

adubo subst. m. Excremento de animais utilizado para adubar aterra. Var. esterco, V. adubo orgânico, V. estrume.

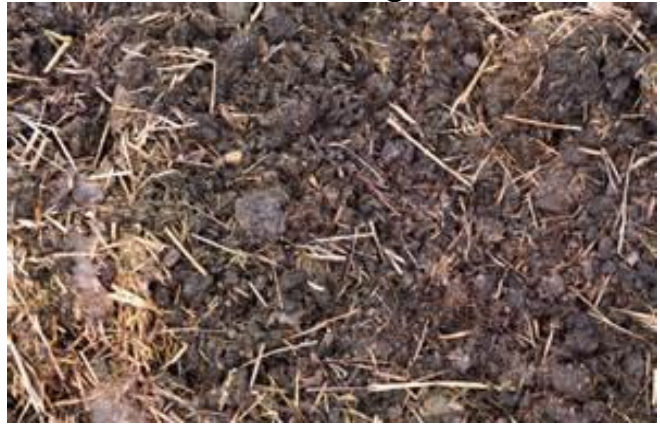

alpendre subst. m. V. curral.

amputação subst. f. castração, V. capação.

aparte subst. m. V. desmame.

bezerro subst. m. V. terneiro, V. novilho.

brete subst. m. subst. m. Lugar onde se coloca o gado para vacinar ou marcar. Var. corredor de manejo.

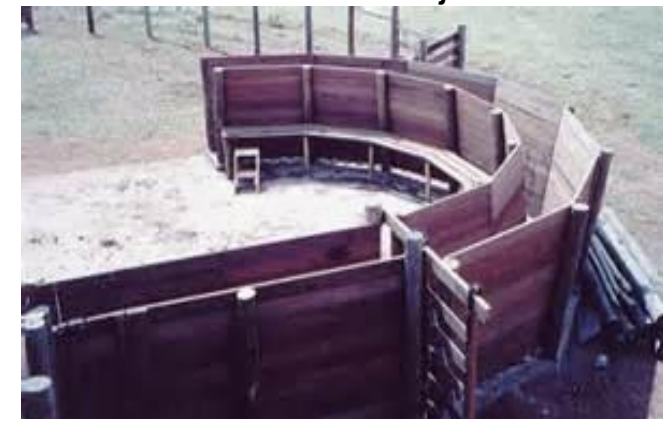


cancela subs. f. V. porteira.

capação subst. f. V. castração, V. amputação.

carrapato subst, m. Parasita que vive no exterior do corpo do hospedeiro, se alimentando do sangue do parasitado. Var. ectoparasita.

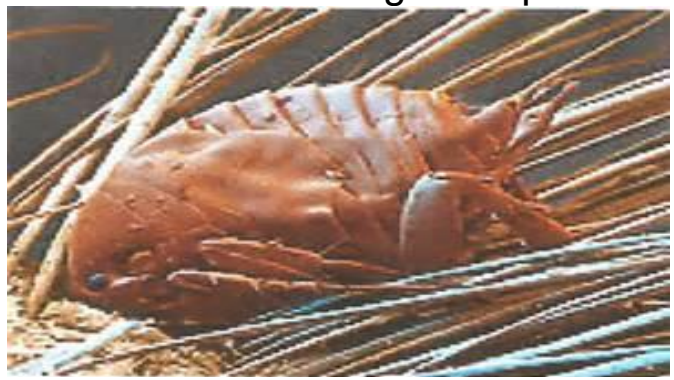

castração subst. f. Ablação dos órgãos genitais do animal, evitando a procriação do mesmo. Var. capação, V. amputação.

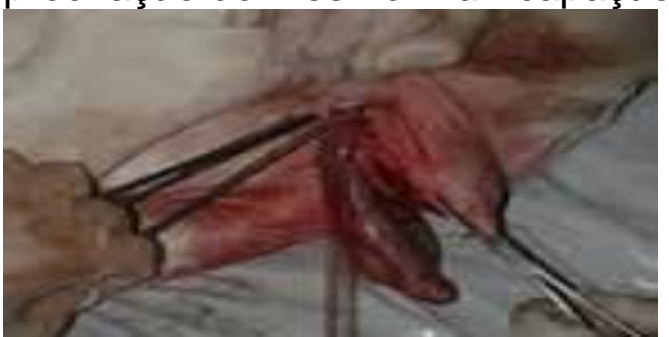

colostro subst. m. Líquido com uma consistência espessa e cor amarela ou transparente, segregado pela glândula mamária durante o período final da gravidez e os primeiros dias depois do parto e, apesar de ser produzido em pequena quantidade, tem na sua composição todos os nutrientes necessários para alimentar adequadamente o animal recém-nascido. Var. leite sujo.

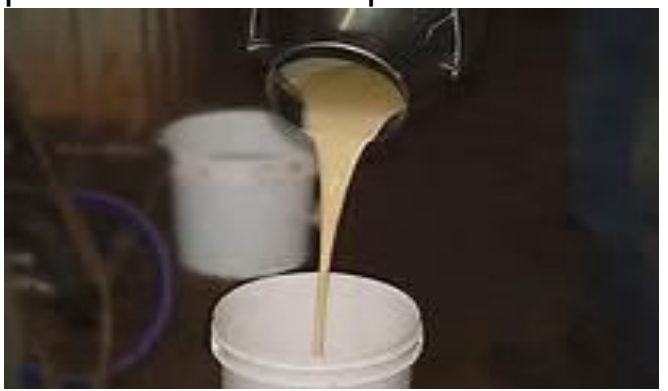

contenção subst. f. Procedimento realizado no animal, para os mais diversos fins, que vão desde a necessidade de um simples exame, aplicação de medicamentos, abate e muitos outros. Var. imobilização, V. amarra do animal.

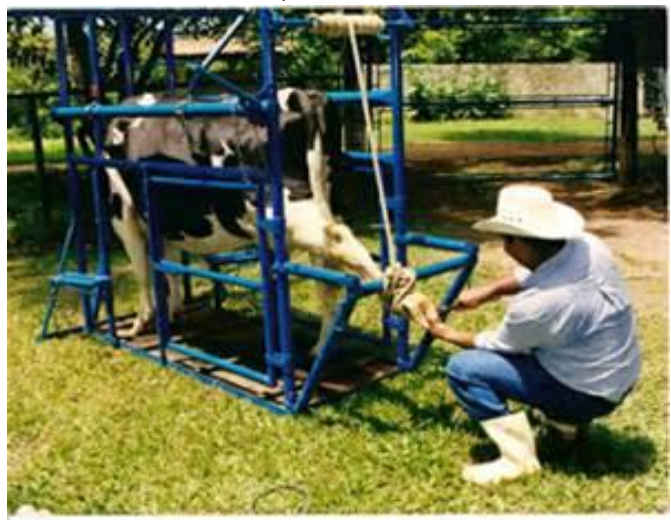

corredor de manejo subst. m. V. brete. 
cupim subst. m. Parte dianteira do animal, mais precisamente atrás do pescoço entremeada de gordura. Var. giba.

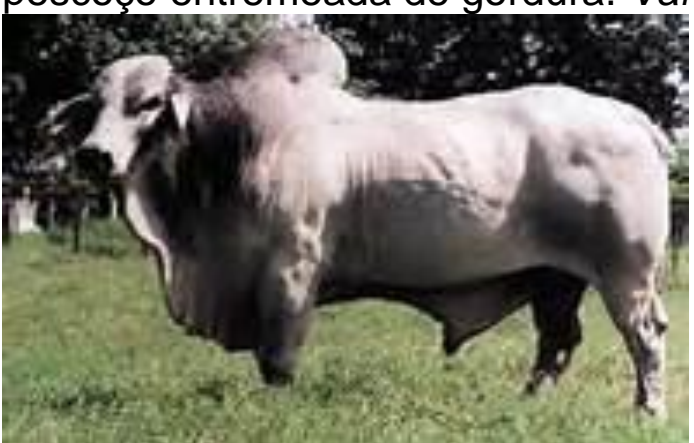

curral subst. m. Local em que são abrigados o gado. Var. alpendre.

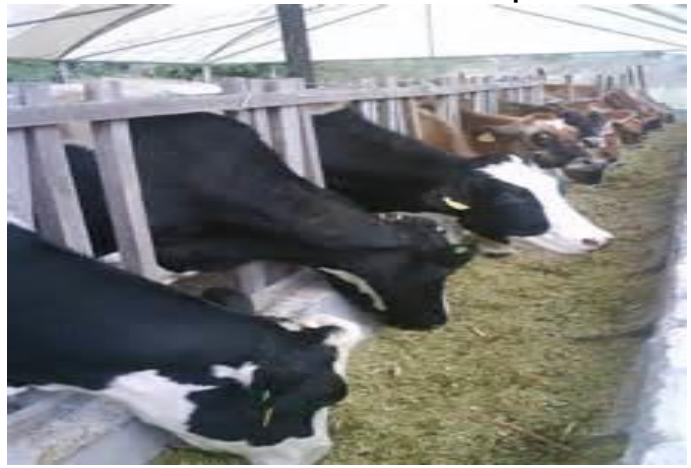

crescimento cespitoso subst. m. V. moita, touceira.

desmame subst. $m$. Desabituação gradual de um bebê ou de uma cria em relação ao leite materno. Var. aparte.

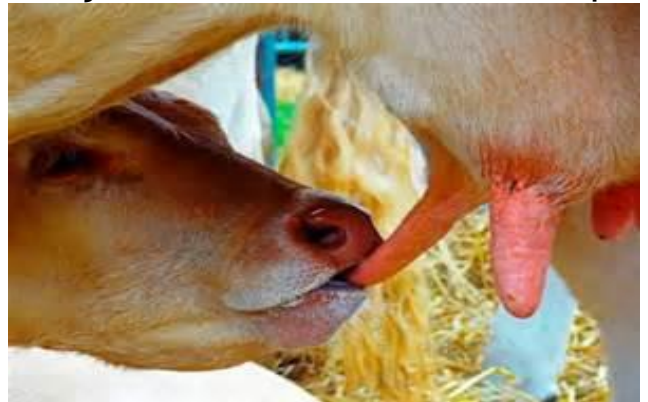

ectoparasita subst. m. V. carrapato.

estaca subst. f. V. mourão.

giba subst. m. V. cupim.

gravidez subst. f. V. prenhes.

insuflador subst. m. V. ordenhadeira, V. teteira.

invernada subst. f. Pasto extenso, destinado à criação de gado e/ou de outros animais, geralmente, delimitado por barreiras naturais ou artificiais. Var. pasto grande.

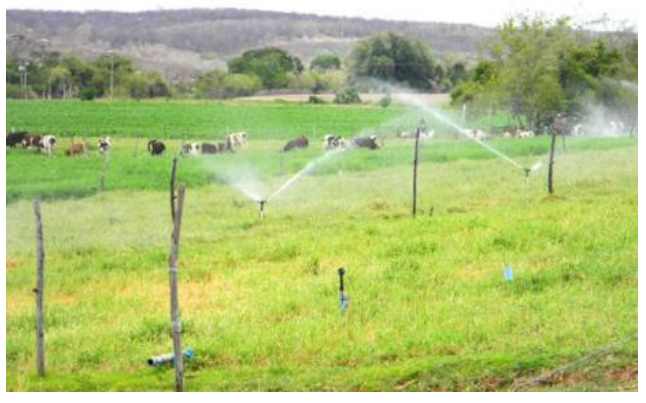


leite sujo subst. m. V. colostro.

manejo subst. $\mathrm{m}$. Conjunto de práticas sistemáticas e necessárias para a cria, recria e engorda do rebanho, desde o primeiros dias de vida até 0 carregamento para o abatedouro. Var. cuidado.

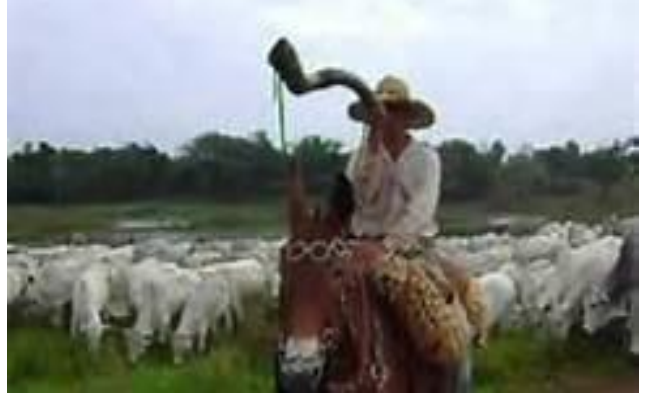

marrafa subst. f. Região ímpar correspondente ao bordo caudal da fronte, situada medianamente à inserção dos cornos. Anatomicamente denominada protuberância intercornual. Var. topete.

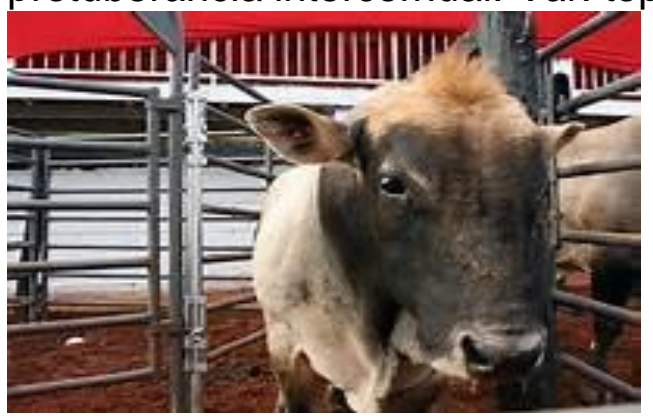

matadouro subst. m. V. abatedouro.

mijo subst. $m$. V. urina.

moita subst. f. Conjunto de planta que nasce e se desenvolve formando tufo. Var. touceira, V. crescimento cespitoso.

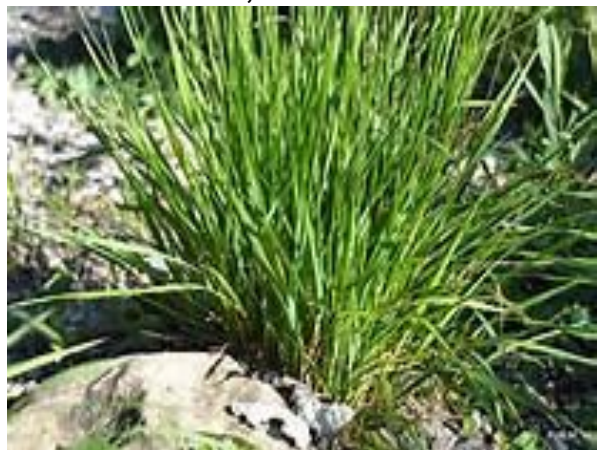

mourão subst. m. Estaca de concreto, madeira ou pedra ao qual se amarram telas, arames, telas ou placas e serve para construir uma cerca. Var. estaca.

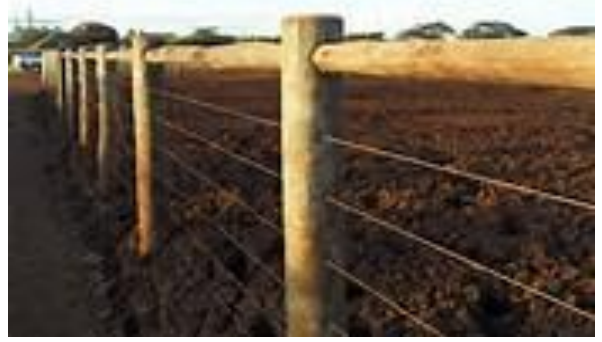

novilho subst. $m$. V. bezerro, terneiro. 
ordenhadeira subst. f. Instrumento usado para sucção do leite, podendo ser automático ou semiautomático. Var, insuflador, V. teteira.

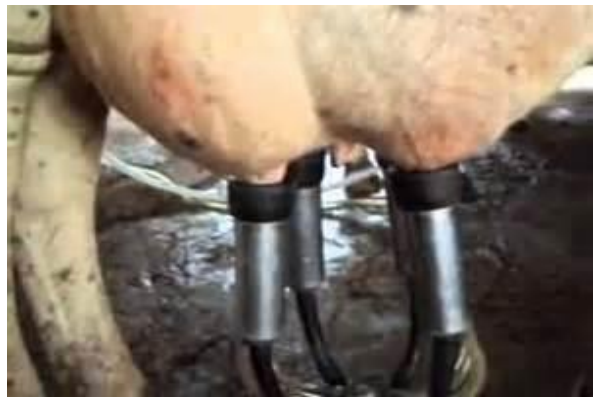

piquete subst. m. Feito geralmente de madeira, mas podendo ser feito também de outros materiais, tem por objetivo abrigar ou reservar o animal, evitando que o mesmo suma, facilitando o manuseio para o produtor. Var. curral.

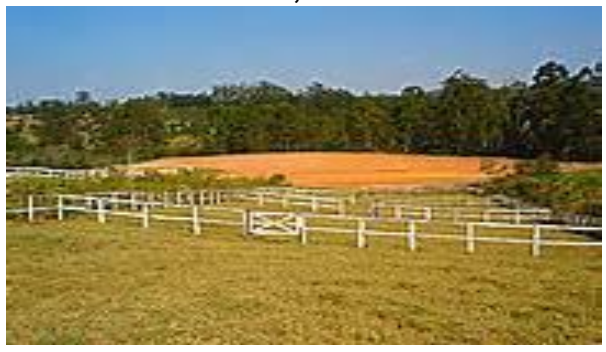

porteira subst. f. Portão de madeira ou metálico que guarnece a entrada de uma propriedade rural. Nota: Tem a finalidade de controlar o trânsito de gado pessoas e veículos, também são utilizadas em currais. Var. cancela.

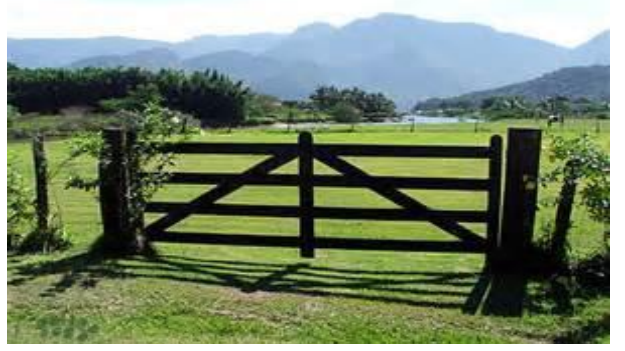

prenhes subst. f. Tempo de desenvolvimento do embrião no útero, desde a concepção até o nascimento, tendo como tempo de duração 284 dias aproximadamente. Var. gravidez.

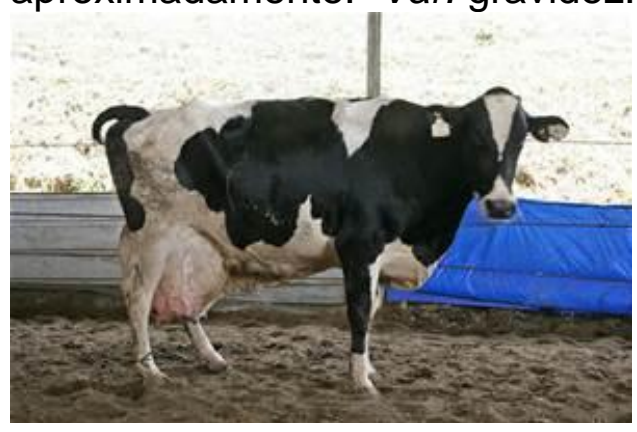


primípara subst. f. Fêmea de um animal que pariu ou vai parir pela primeira vez.

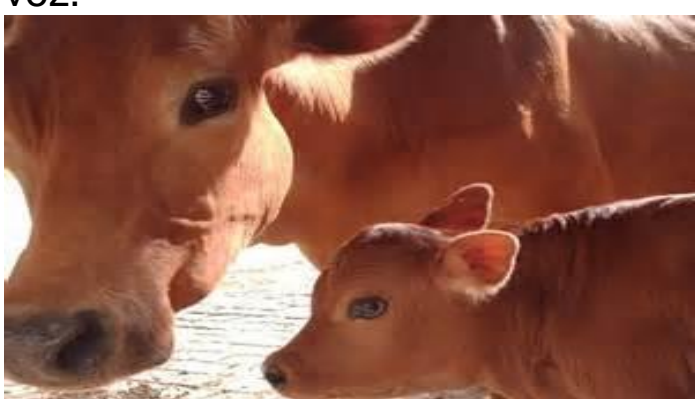

terneiro subst. $m$. Filhote de boi e vaca que se encontra na idade de 1 a 6 meses, impróprio ainda para o abate, mas tem larga utilização na recria e engorda. Var. bezerro, V. novilho.

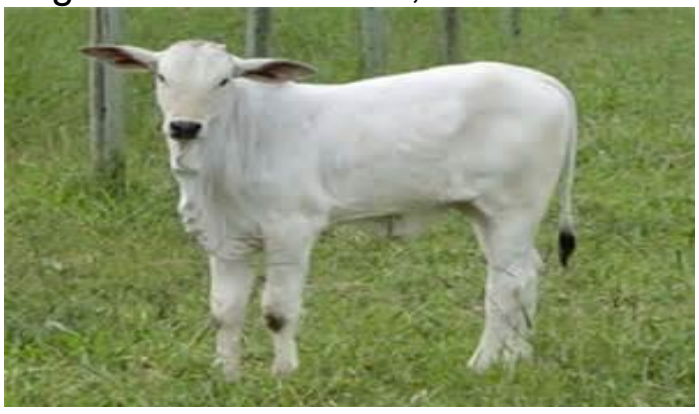

teteira subst. f. V. ordenhadeira, V. insuflador.

touceira subst. f. V. crescimento cespitoso, V. moita.

topete subst. m. V. marrafa.

urina subst. f. Líquido orgânico que contém substâncias metabólicas a serem eliminadas, que se forma nos rins e é coletado na bexiga e depois é expelido pela uretra. Var. mijo.

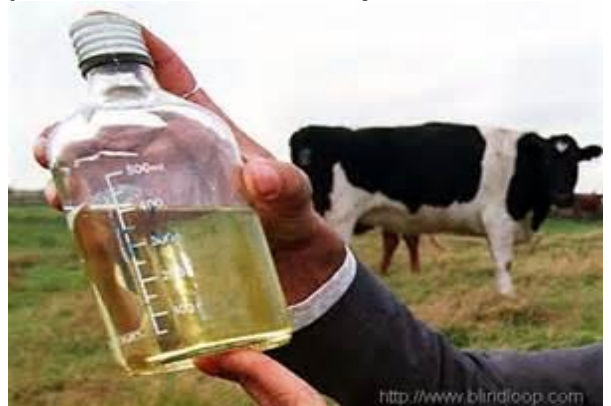

vaca infértil subst. f. Fêmea desprovida da capacidade de reprodução. Var. vaca manina.

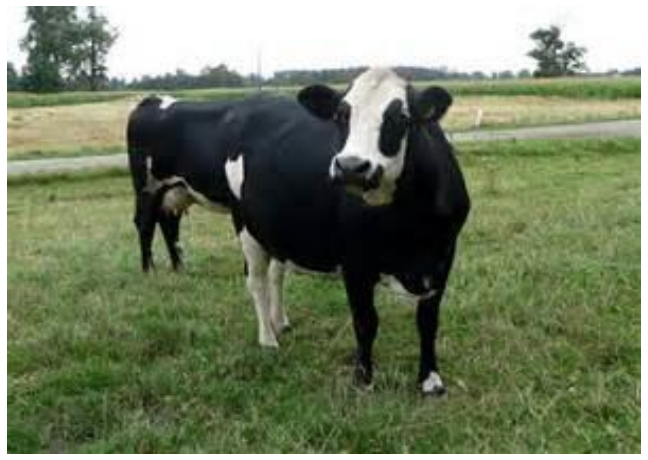

vaca manina subst. f. $V$. vaca infértil. 


\subsection{4 - GLOSSÁRIO DE TERMINOLOGIAS DA HORTICULTURA}

aberração subst. f. Irregularidade que ocorre na planta, deformidade, monstruosidade da planta. Var. anomalia, V. defeito.
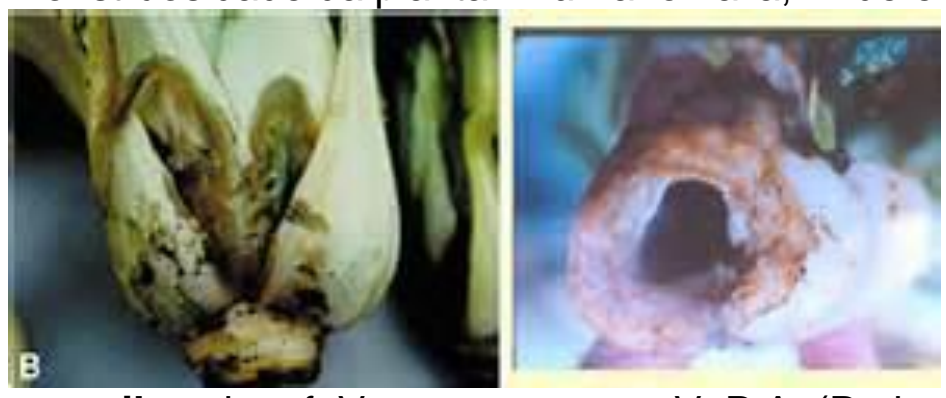

agrovila subst. f. V. assentamento, V. P.A. (Projeto de Assentamento).

amadurecimento subst. $\mathrm{m}$. Processo de desenvolvimento da planta ou de suas partes no sentido de tornar o organismo apto para a reprodução. Var. maturação.

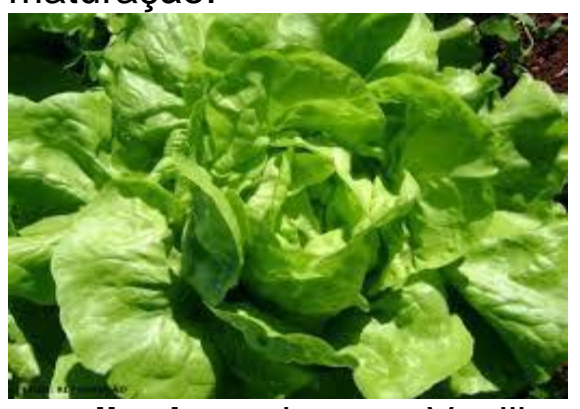

amolhador subst. m. Vasilhame de caráter pequeno ou mediano, usado para irrigar/molhar plantas ou solo, composto por bacia, bico ligeiramente alongado e um chuveiro na ponta do bico. Var. regador.

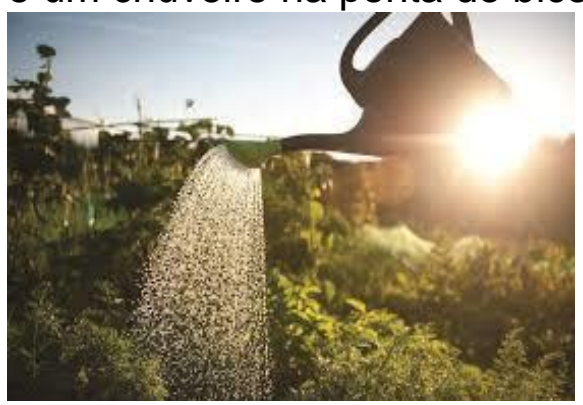

anomalia subst. f. V. aberração, V. defeito.

ancinho subst. m. V. rastelo.

aparência subst. f. Características apresentadas por um indivíduo, sejam elas morfológica, fisiológica e comportamental. Var. fenótipo.

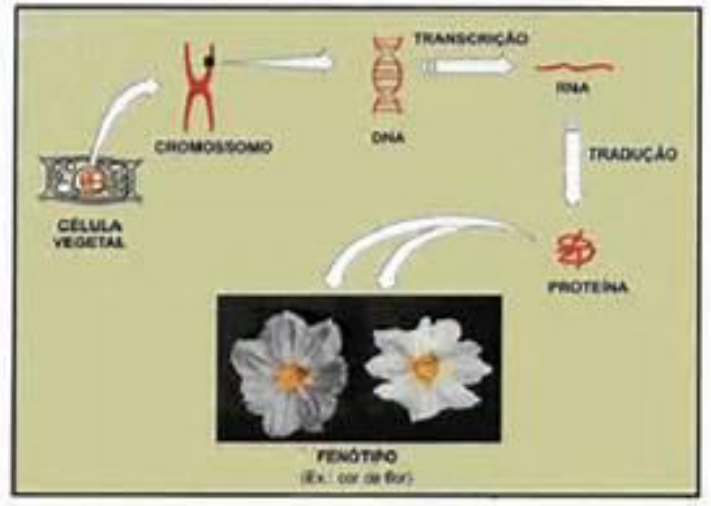


aplainamento subst. m. Operação cujo objetivo é reduzir o volume de vazios num solo granuloso ou no concreto em massa, para obter maior coesão e resistência e diminuir sua permeabilidade. Var. compactação.

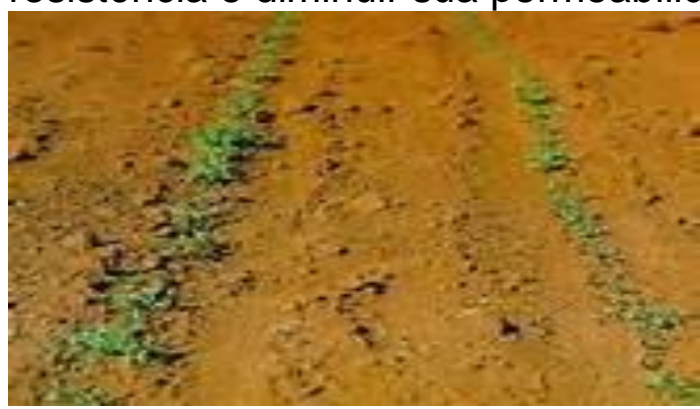

argila subst. f. V. barro, greda.

assentamento subst. m. Núcleo populacional instalado à margem de estradas de desbravamento, como a Transamazônica, e destinado a atividades agrícolas. Var. agrovila, V. P.A. (Projeto de Assentamento).

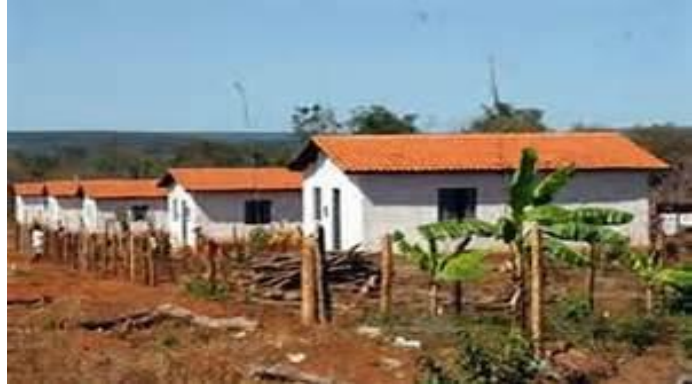

associação subst. f. V. roça misturada.

barro subst. $m$. Terra vermelha, amarela ou branca, composta principalmente de alumina e sílica, que é utilizada na fabricação de telhas, tijolos, vasos, potes. Var. argila, V. greda.

buraco subst. $m$. V. voçoroca, erosão.

branqueamento da folha subst. $\mathrm{m}$. Alteração mórbida das plantas produzida por falta de luz, descoramento e enfraquecimento dos indivíduos que vivem privados da luz e do ar puro. Var. estiolamento, V. esmorecimento, V. caimento.

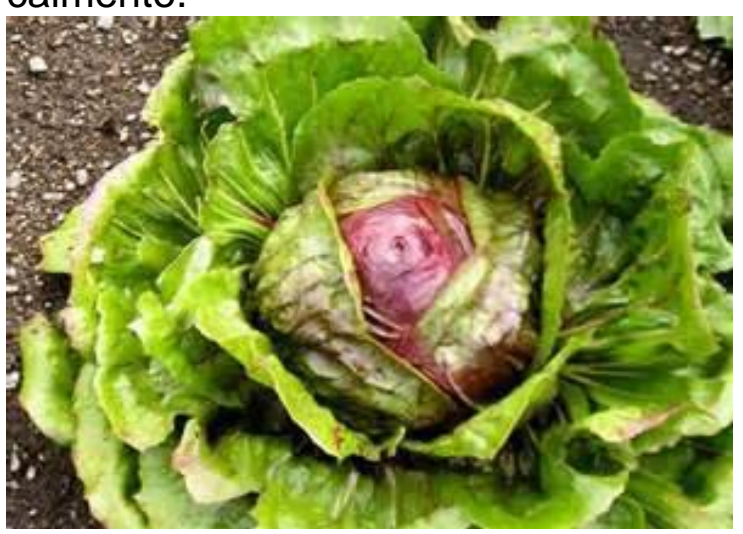


broto subst. $\mathrm{m}$. Parte da planta que se localiza na extremidade do caule ou dos ramos e é formada por células que se reproduzem intensamente, que promovem o crescimento do mesmo. Var. gema, V. olho.

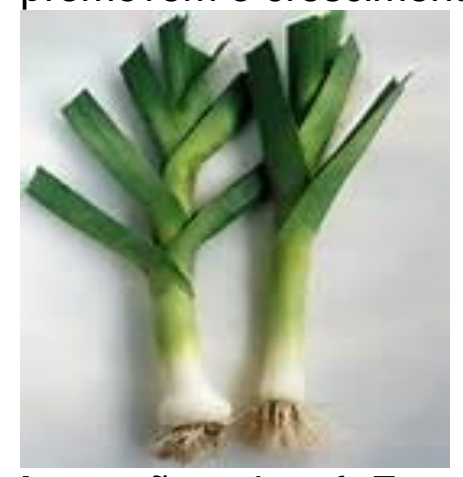

brotação subst. f. Etapa em que há a quebra da dormência da semente e esta inicia seu desenvolvimento. Var. germinação, V. emergência, V. nascimento.

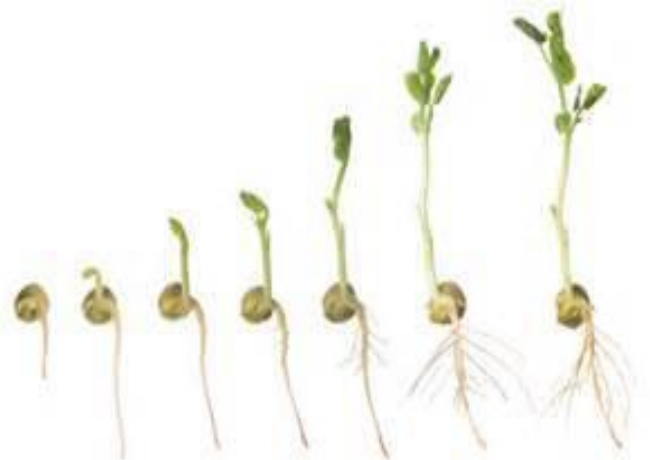

caimento subst. m. V. branqueamento da folha.

cama subst. f. V. forragem.

camalhão subst. m. V. terra lavrada.

campo subst. m. Extensão de terra, arável ou arada, terreno fora das cidades onde se faz uso para o cultivo ou moradia em menor número de população. Var. roça.

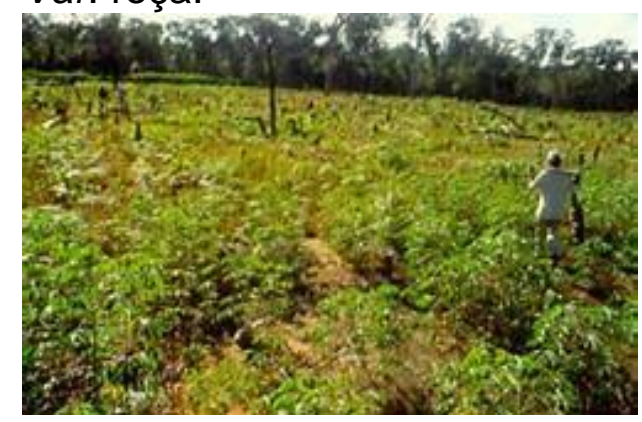

canal subst. m. V. rego, V. linha.

caule subst. $m$. V. talo.

compactação subst. f. V. aplainamento.

solo subst. m. Camada superficial da crosta terrestre, sendo formado basicamente por aglomerados minerais e matéria orgânica oriunda da decomposição de animais e plantas. Var. terra. 
debuia subst. $m$. Ato de retirar das espigas ou vagens os grãos com as mãos ou por meio de maquinários. Var. debulha.

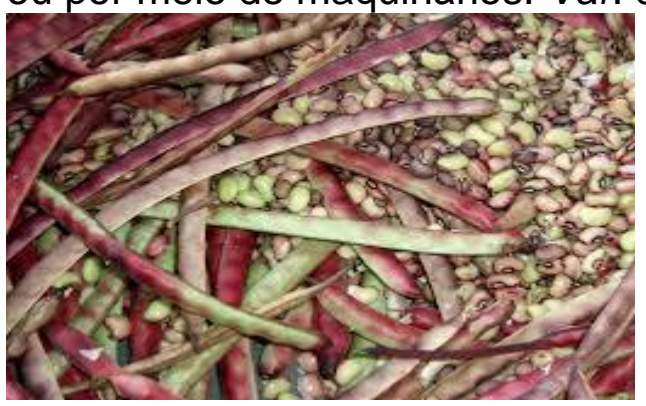

debulha subst. f. V. debuia.

defeito subst. m. V. anomalia, V. aberração.

defensivo agrícola subst. $m$. $V$. veneno, $V$. fungicida.

doença subst. f. V. praga.

erosão subst. f. Processo pelo qual a camada superficial do solo ou partes do solo é retirada pelo impacto de gotas de chuva, ventos e ondas e são transportadas e depositadas em outro lugar. Var. voçoroca, V. buraco.

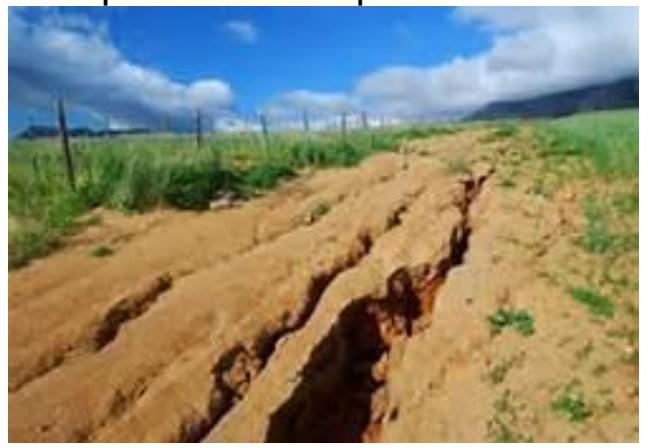

esmorecimento subst. $\mathrm{m}$. V. branqueamento da folha.

esterco subst. m. Fertilizante básico para a produção da agricultura orgânica, que além de respeitar o meio ambiente, produz alimentos saudáveis, livres de fertilizantes químicos, prejudiciais ao solo e à saúde humana. Var. matéria orgânica, V. estrume.

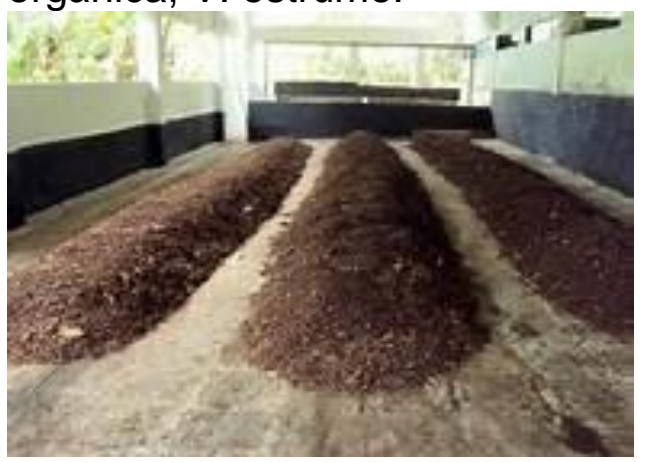

estiolamento subst. m. V. branqueamento da folha, V. esmorecimento, V. caimento.

estrume subst. m. V. esterco, V. matéria orgânica.

erva daninha subst. f. V. mato.

fenotipo subst. $m$. V. aparência. 
forragem subst. f. Camada usada para incorporar nutrientes ao solo ou para cobri-lo, sendo ele de origem vegetal ou animal. Var. cama.

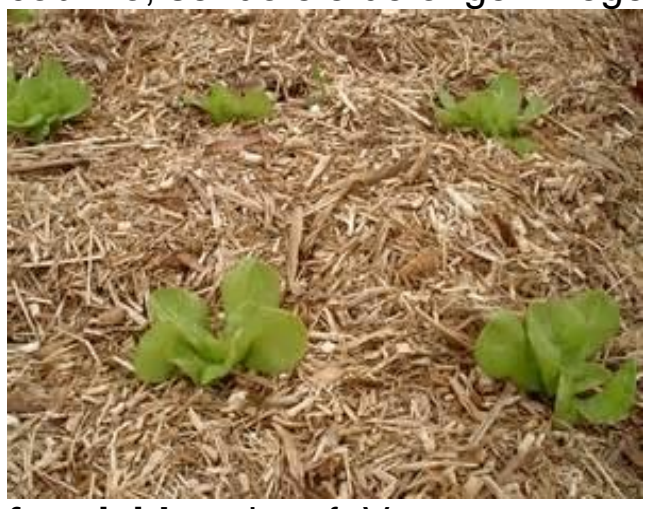

fungicida subst. f. V. veneno.

gema subst. f. V. broto, olho.

germinação subst. f. V. brotação.

greda subst. f. V. barro.

hortaliça subst. f. V. verdura.

jirico subst. m. Veículo motorizado que se desloca sobre grandes rodas ou esteiras de aço e serve para arados, grades de discos, rebocar carretas, cargas, executar serviços de terraplanagem. Var. trator.

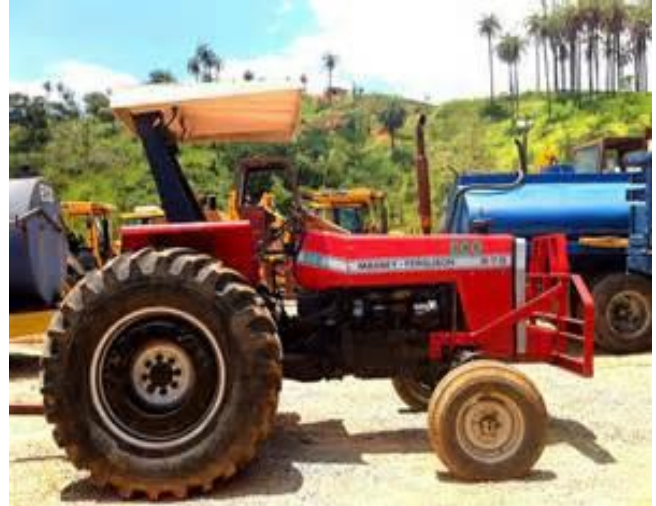

linha subst. $f$. Resultado da intervenção de uma enxada em canteiros baixos ou suspensos, de modo a escavar para o plantio das sementes ou mudas, charrua ou trator agrícola. Var. sulco, V. rego, V. canal, V. leira.

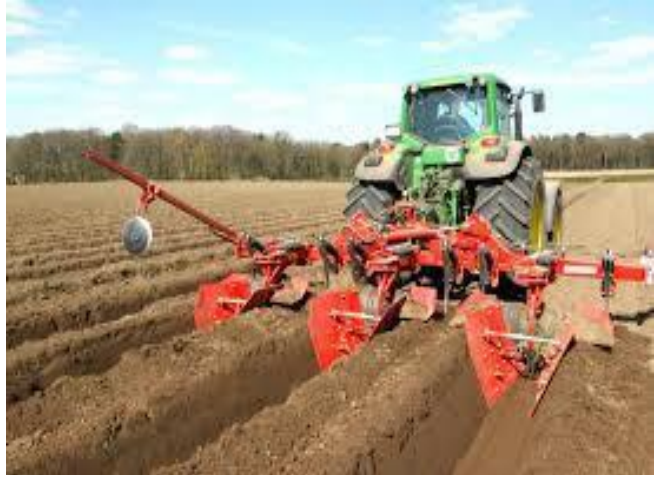

leira subst. f. V. linha

manta de terra subst. f. V. terra lavrada, V. camalhão. 
mato subst. m. Planta que nasce espontaneamente em locais e momentos indesejados, sendo exóticas ou não, podendo interferir negativamente na agricultura. Var. ervas daninhas.

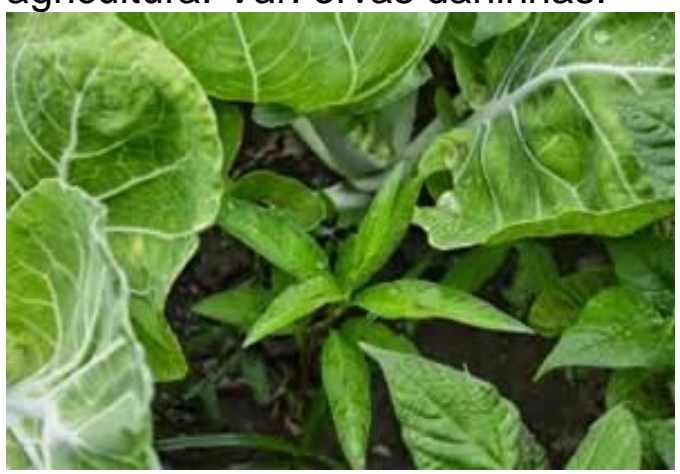

maturação subst. f. V. amadurecimento.

patógeno subst. $\mathrm{m}$. V. praga, V. doença.

panícula subst. f. V. pendão.

P.A. subst. m. Projeto de Assentamento. V. agrovila.

pedicelo subst. $\mathrm{m}$. V. pendão, V. panícula.

pendão subst. $m$. Estrutura originada da modificação do caule, responsável pela sustentação e condução de seiva para as flores. Var. pedúnculo, V. pedicelo, V. panícula.

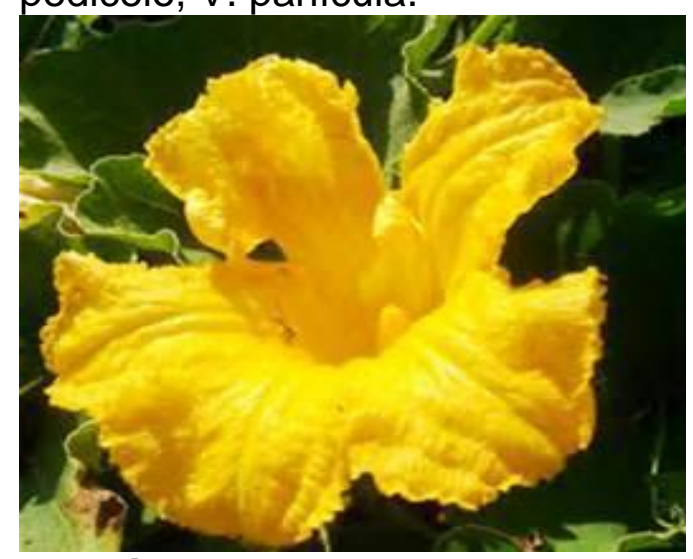

pendúnculo subst. $\mathrm{m}$. V. pendão, pedicelo, panícula.

policultivo subst. $\mathrm{m}$. $\mathrm{V}$. roça misturada.

praga subst. f. Agente biológico capaz de causar alterações no sistema da planta, provocando danos físicos e fisiológicos a ela. Var. patógeno, V. doença.

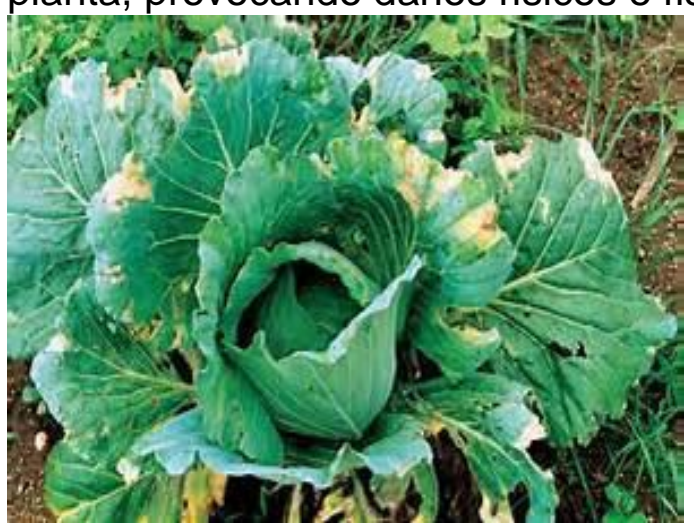


rastelo subst. $\mathrm{m}$. Instrumento agrícola constituído por uma barra ou travessa com dentes ou pontas, presa a um cabo longo, e que se destina a juntar palha, folhas secas, gradar canteiros etc. Var. ancinho.

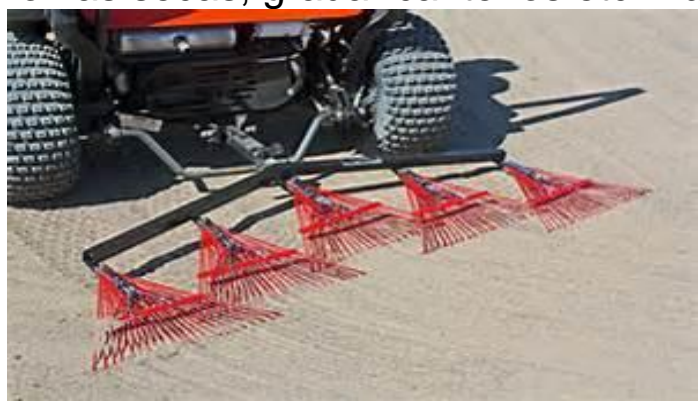

regador subst. $\mathrm{m}$. V. amolhador.

rego subst. $\mathrm{m}$. Escavação linear caracterizada por apresentar profundidade maior que a largura, escavação longa e mais ou menos estreita na extremidade de um terreno, para escoamento das águas pluviais. Var. canal, V. vala.

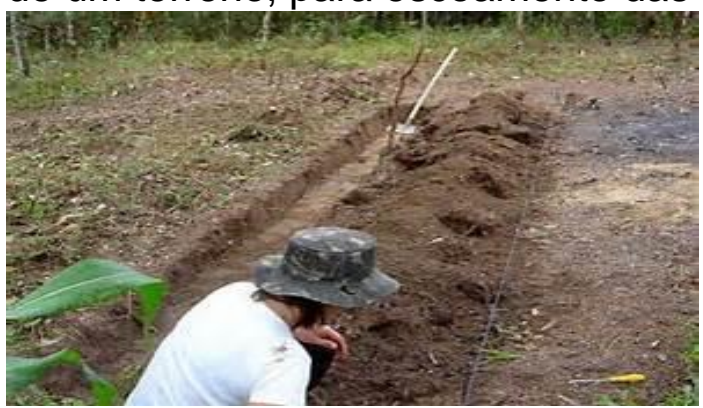

roça misturada subst. f. Sistema de exploração do solo, que consiste em obter vários tipos de produtos numa mesma propriedade, numa mesma região, associada aos minifúndios. Var. policultivo, V. associação.

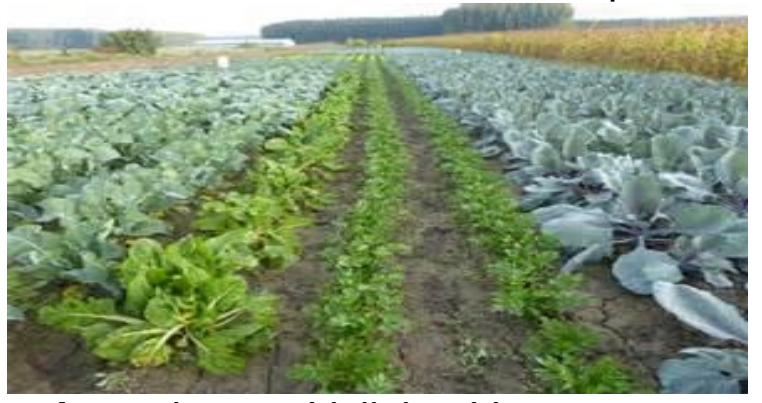

sulco subst. m. V. linha, V. rego.

talo subst. $\mathrm{m}$. Parte da planta que promove a integração de raízes e folhas, tanto do ponto de vista estrutural como funcional e desempenha as funções de condução de água e sais minerais das raízes para as folhas, e de condução de matéria orgânica das folhas para as raízes. Var. caule.

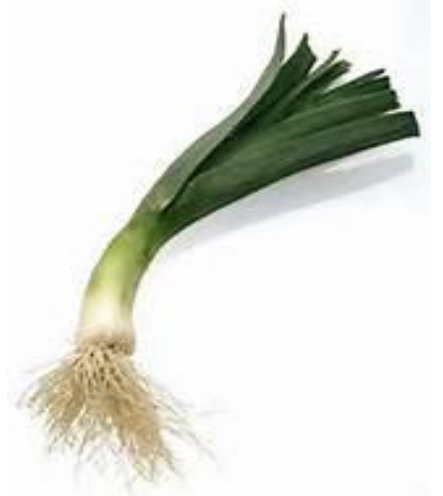


terra lavrada subst. f. Porção de terra disposta para sementeira entre dois sulcos; beira, leiva. Var. camalhão, V. gleba, V. manta de terra.

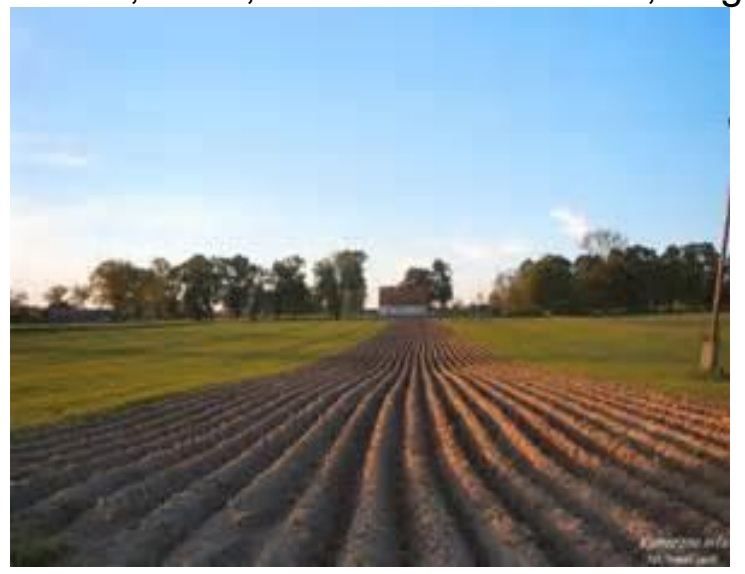

trator subst. m. V. jirico.

vala subst. f. V. canal, rego.

veneno subst. $m$. Substância química usada para destruir organismos indesejados nas plantações e em outros locais além dos campos. Var. fungicida, V. defensivo agrícola.

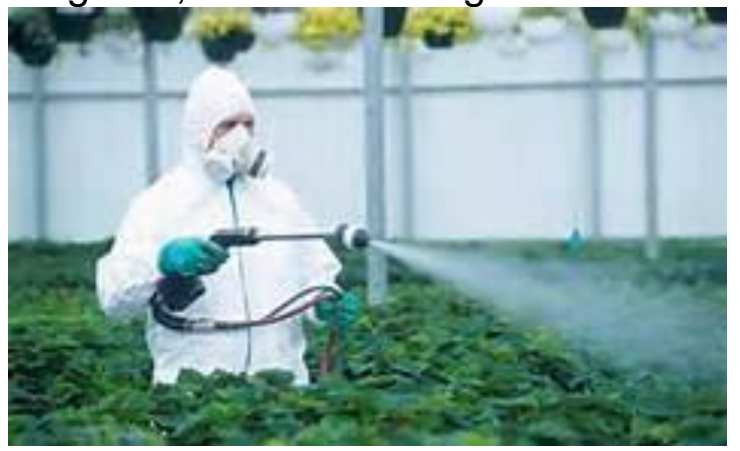

verdura subst. f. Designação genérica das plantas cultivadas em hortas e reservadas para uso culinário. Var. hortaliça.

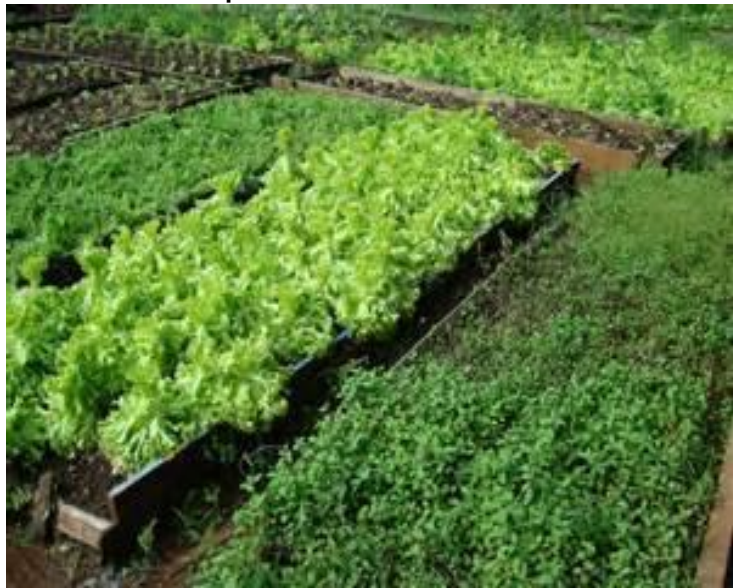

voçoroca subst. f. V. erosão. 


\subsection{5 - GLOSSÁRIO DE TERMINOLOGIAS DA SUINOCULTURA}

aborto subst. m. Descontinuação dolosa da prenhes, com ou sem expulsão do feto, da qual resulta a morte do nascituro. Var. perda embrionária.

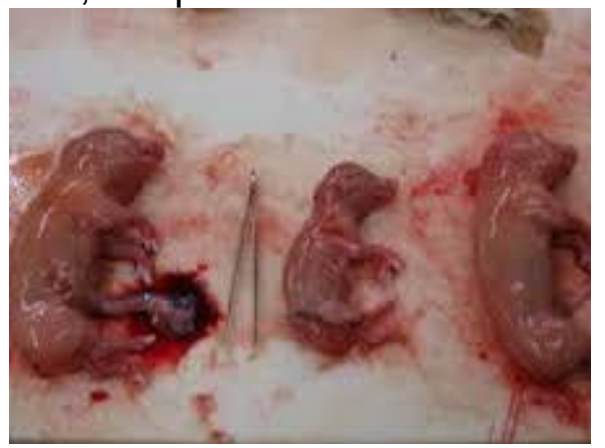

abrigo subst. m. V. escamoteador.

acasalamento subst. $m$. V. cruzamento, V. cobertura.

amputação subst. f. V. castração, V. capação.

baia subst. f. Local destinado ao confinamento animal. Var. box, V. chiqueiro.

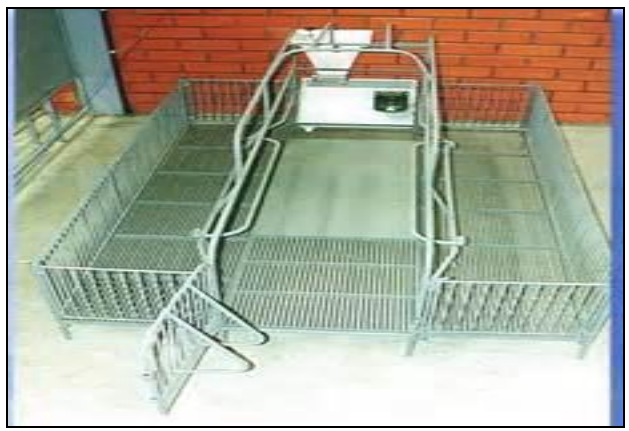

banha subst. f. Qualquer substância untuosa, de origem animal ou vegetal usado na preparação de alimentos. Var. gordura.

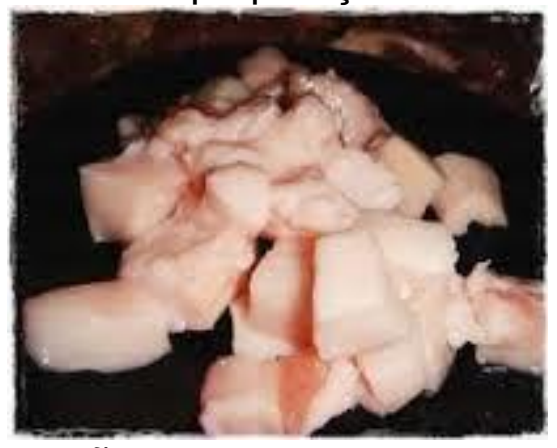

barrão subst. m. Animal ligeiramente robusto e não castrado, responsável pela monta da fêmea e reprodução da espécie. Var. cachaço.

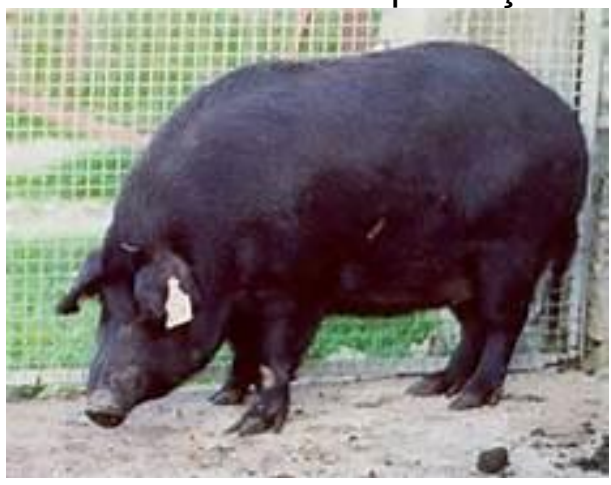


beiral subst. m. Prolongamento do telhado para além da parede externa, protegendo-a da ação das chuvas. Var. calha, V. biqueira.

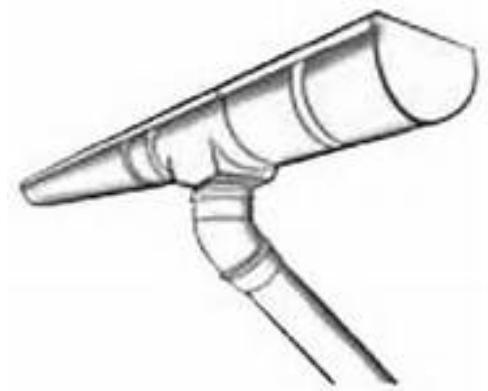

bicheira subst. f. Doença causada pela invasão do tecido cutâneo por larvas de moscas, que afeta diversas espécies de animais, inclusive humanos. Var. miíase.

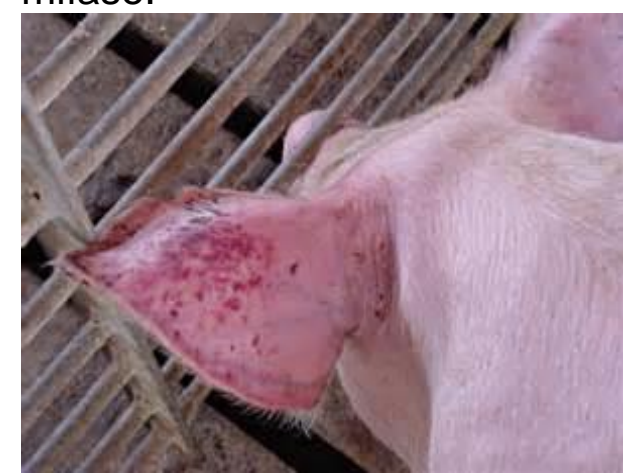

biqueira subst. f. V. beiral, V. calha.

box subst. m. V. baia, V. chiqueiro.

brete subst. m. Lugar onde se coloca o animal para vacinar e fazer marcação de animais com ferro quente. Var. corredor de manejo, V. tronco.

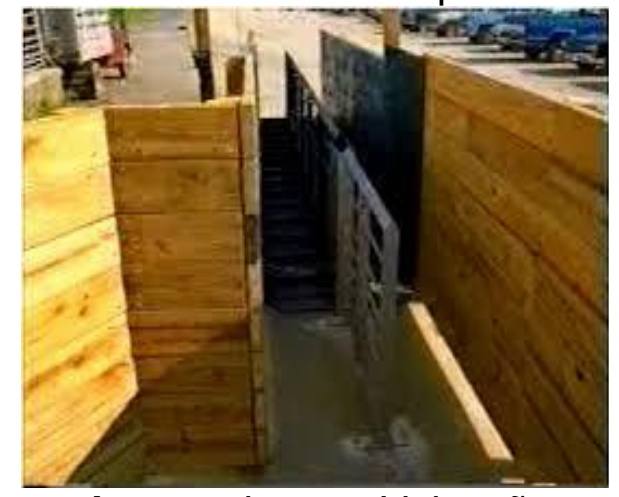

cachaço subst. m. V. barrão.

calha subst. f. V. beiral, V. biqueira.

capação subst. m. V. castração, V. amputação.

castração subst. f. Ablação dos órgãos genitais do animal, evitando a procriação do mesmo. Var. capação, V. amputação.

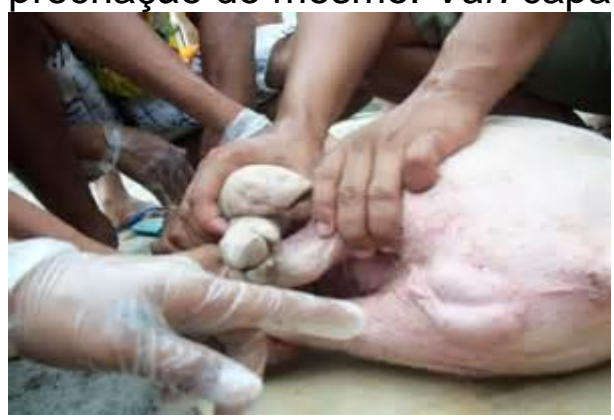


cio subst. $\mathrm{m}$. Período em que a fêmea aceita a monta, ou, o período em que ela fica parada, enquanto outro animal salta sobre ela. É um fenômeno fisiológico caracterizado principalmente pelas mudanças no seu comportamento. Var. viço.

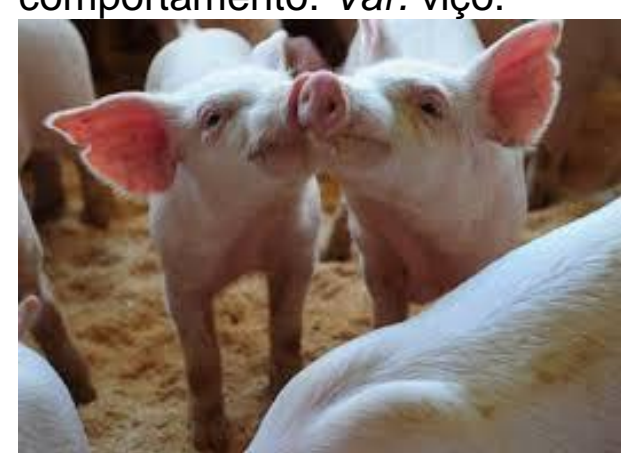

cobertura subst. f. V. cruzamento, acasalamento.

constipação subst. m. Retenção exagerada de fezes, evacuação infrequente, dificuldade para evacuar, eliminação de fezes duras ou em pequeno volume. Var. obstipação, V. prisão de ventre.

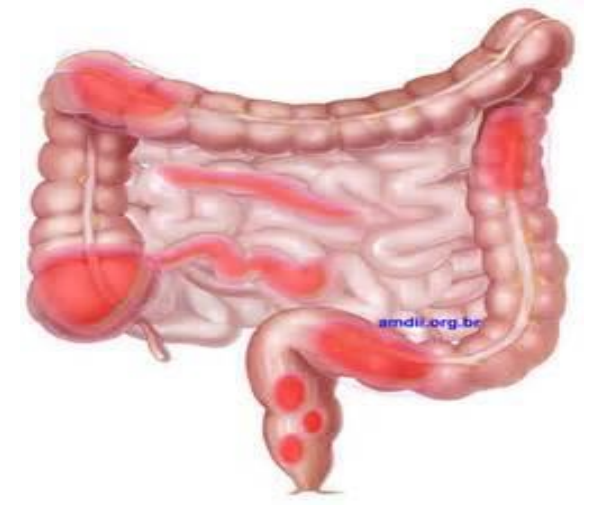

corredor de manejo subst. m. V. brete, tronco.

costas subst. f. V. lombo.

cumeeira subst. f. V. lanternim.

chiqueiro subst. $\mathrm{m}$. Construção ou lugar em que se recolhe/confina a criação de porcos, possuindo diferentes fases de vida. Var. Pocilga.

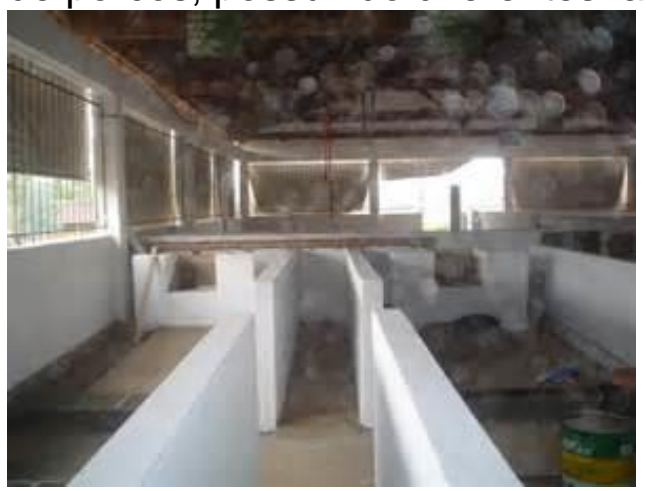


cruzamento subst. m. Ato ou efeito de cobrir, cópula de animais quadrúpedes. Var. monta, V. acasalamento, V. cobertura.

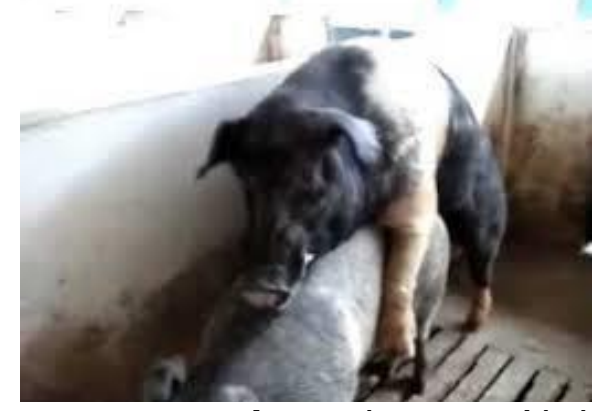

escamoteador subst. m. Abrigo fechado para a proteção de recém-nascidos contra o esfriamento e deve estar instalado junto à baia de maternidade. Var. abrigo.

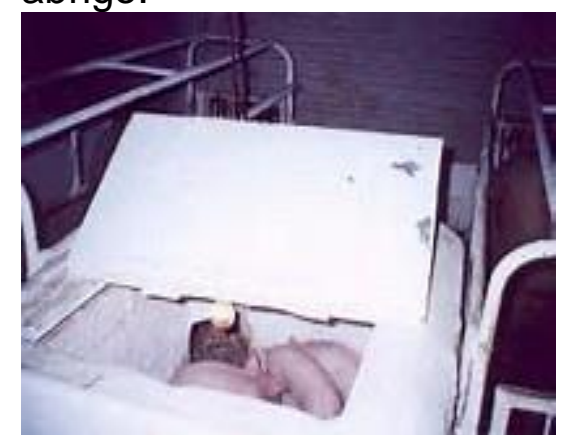

escatol subst. m. Composto químico cristalino, uma amina, de fórmula $\mathrm{C} 9 \mathrm{H} 9 \mathrm{~N}$, de número CAS 83-34-1, medianamente tóxico, possui um cheiro desagradável e forte de fezes.

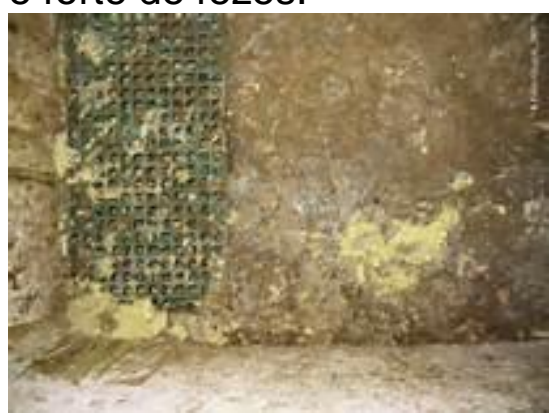

flanco subst. m. Região par situada posteriormente ao costado, adiante da anca e da coxa, abaixo do lombo e acima do ventre, anatomicamente denominada fossa paralombar. Var. vazio, V. ilha.

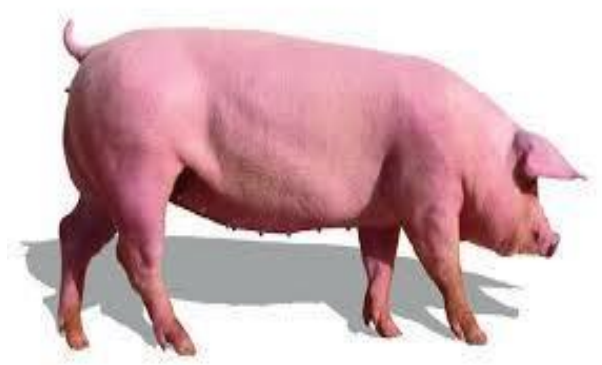

gestante subst. f. V. prenha. gordura subst. f. V. banha. 
galpão suíno subst. $\mathrm{m}$. Local destinado à estadia de animais em criação confinada ou não, desde o nascimento até a saída para abatimento. Var. instalação.

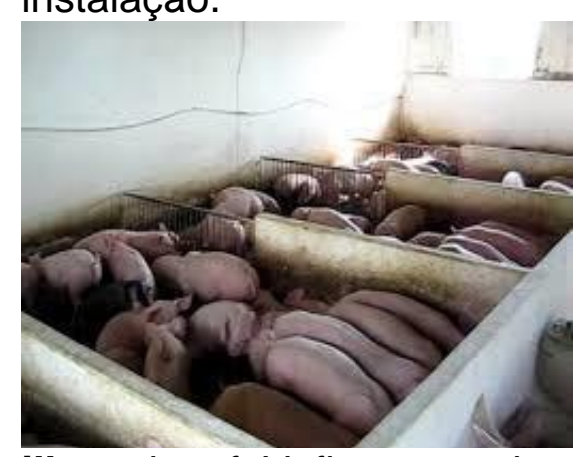

ilha subst. f. V. flanco, vazio.

inchaço subst. m. Infecção geralmente causada pela bactéria Staphylococcus aureus e que provoca vermelhidão e inchaço na zona que circunda o umbigo, cujos sintomas são: febre, saída de um líquido seroso, por vezes manchado de sangue. Var. onfalite.

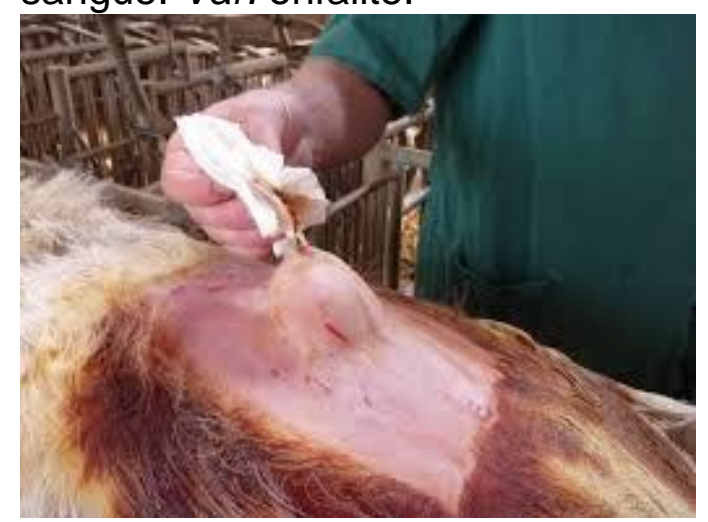

instalação subst. f. V. galpão suíno.

lanternim subst. $\mathrm{m}$. Pequeno telhado sobreposto às cumeeiras que serve para propiciar ventilação e iluminação naturais dos ambientes. Var. cumeeira.

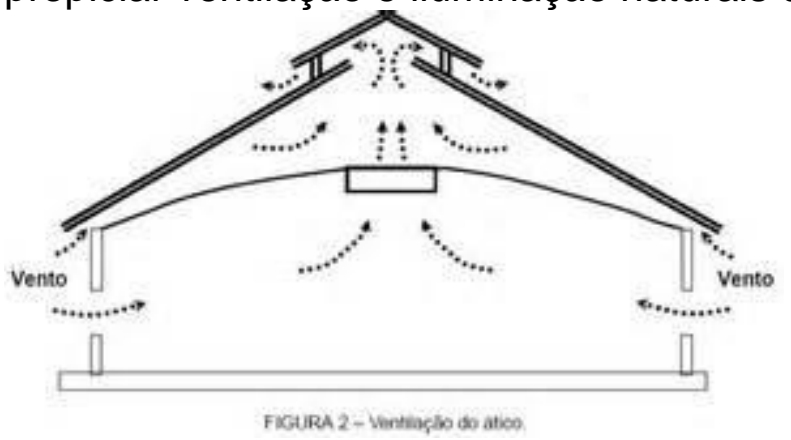

leitoa virgem subst. f. V. marrã, V. porca virgem.

linhagem subst. f. V. raça. 
lombo subst. m. Parte carnosa que compreende os músculos da região renal e da nuca, composta de filé, contrafilé e alcatra. 2. Parte carnosa pegada à espinha dorsal de um lado e de outro, superfície exterior ou convexa. Var. suam, V. suã, V. costas.

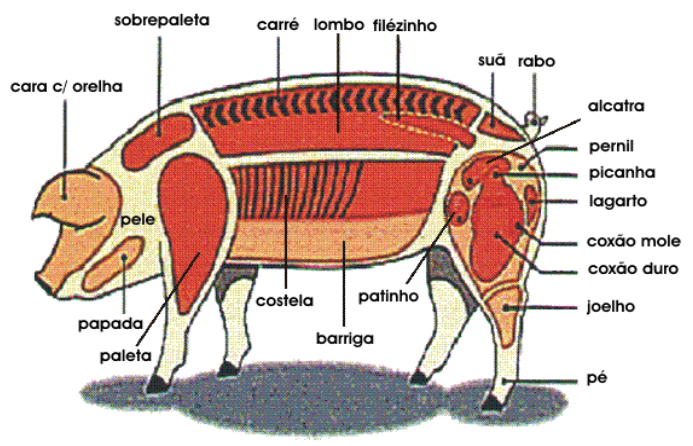

mama subst. f. V. teta, peito.

marra subst. f. Fêmea desmamada que ainda não iniciou seu ciclo de reprodução. Var. leitoa virgem; V. porca virgem.

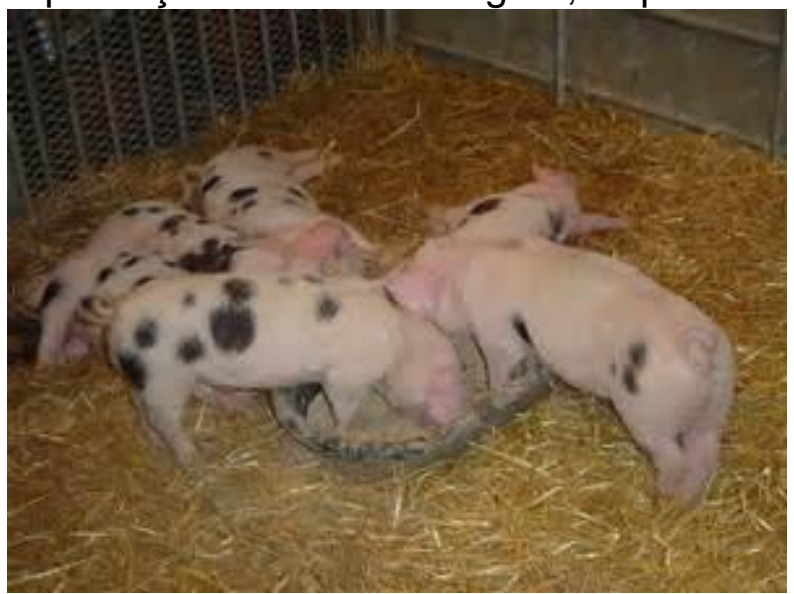

miíase subst. f. V. bicheira.

onfalite subst. f. V. inchaço.

obstinação subst. f. V. constipação, V. prisão de ventre.

peito subst. m. V. mama, V. teta.

perda embrionária subst. f. V. aborto.

pocilga subst. f. $V$. chiqueiro.

porca virgem subst. f. V. marrã, V. leitoa virgem.

plantel subst. m. V. rebanho.

prenha adj. f. Estado da fêmea após a fecundação de um óvulo pelo espermatozoide, envolvendo também o subsequente desenvolvimento, no útero, do feto que foi gerado pela fecundação, encerrando-se na expulsão, chamada de "parto" ou "nascimento". Var. gestante.

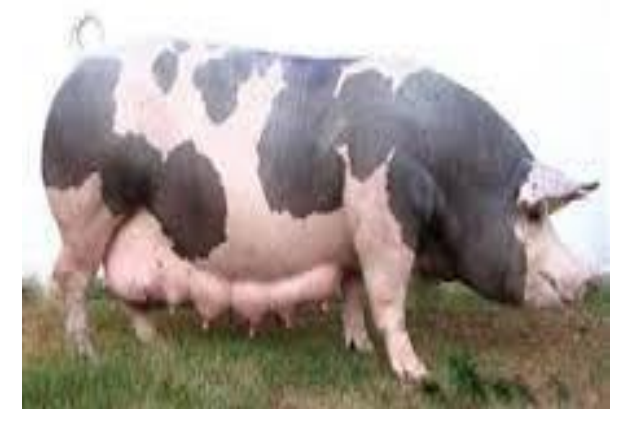


prisão de ventre subst. f. V. obstinação, V. constipação.

raça subst. f. Série de gerações de um animal que apresenta linha de parentesco, genealogia ou estirpe. Var. linhagem.

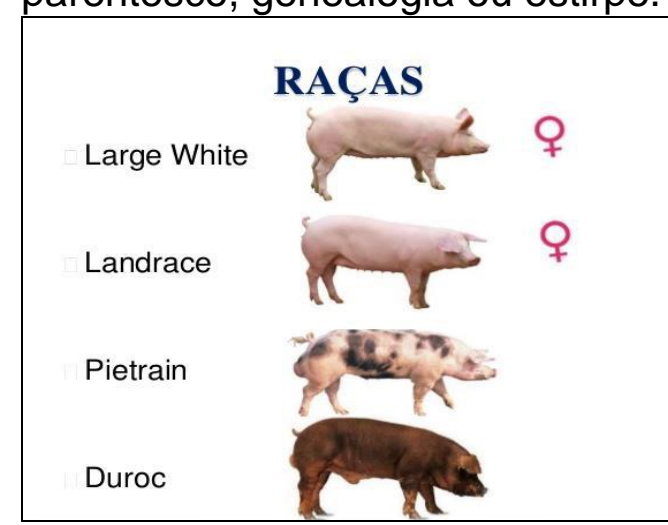

rebanho subst. $\mathrm{m}$. Lote de animais de boa raça, reservados para a reprodução. Var. plantel.

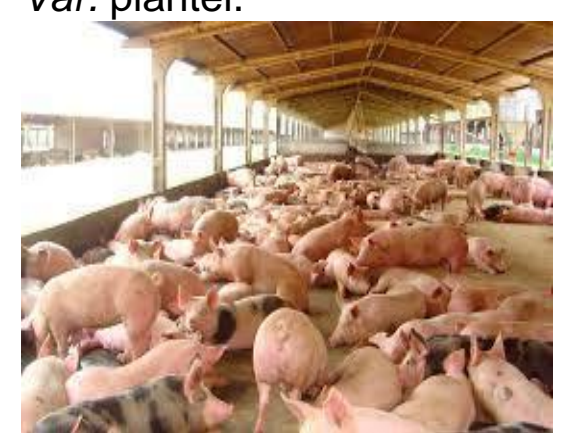

suam subst. m. V. lombo.

suã subst. m. V. lombo.

teta subst. f. Órgão secretor responsável pela distribuição do líquido alimentar, essencial para o animal em seus primeiros meses de vida. Var. mama, V. peito.

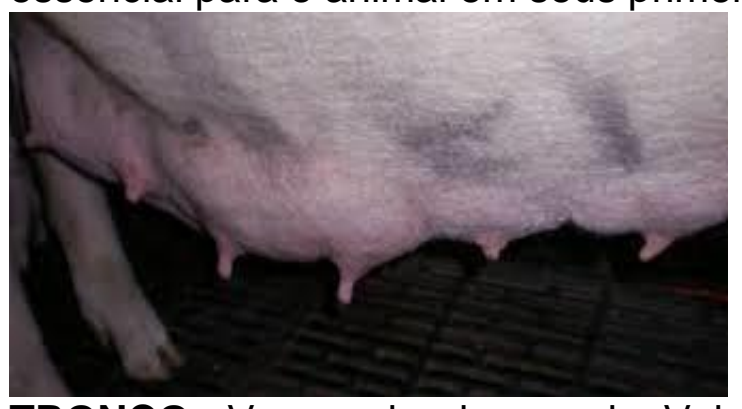

TRONCO - V. corredor de manejo, V. brete.

vazio subst. $m$. V. flanco, $V$. ilha.

viço subst. $m$. V. cio. 


\section{CONSIDERAÇÕES FINAIS}

Esta pesquisa possibilitou analisar as variações dos termos presentes na área da Agropecuária e suas subáreas, apicultura, avicultura, horticultura, bovinocultura e a suinocultura com vistas a observar o papel do técnico em Agropecuária junto aos profissionais técnicos e os assentados, agricultores, estudantes no uso da língua de especialidade e a língua comum.

A metodologia adotada foi, inicialmente, o trabalho com os estudantes do Ensino Médio Integrado ao curso Técnico na área de Agropecuária na análise de textos na componente curricular - Língua Portuguesa - sob a responsabilidade desta pesquisadora. O passo seguinte foi listar os termos de cinco subáreas da agropecuária: apicultura, avicultura, horticultura, bovinocultura e a suinocultura (Anexo 2) e fazer a correspondência dos termos técnicos com base no conhecimento dos estudantes, uma vez que muitos deles são assentados ou a família trabalha no campo e faz uso de determinado termo para designar os procedimentos, métodos e instrumentos da área e, submetêlos à validação dos usuários desses termos, quer dizer, os assentados dos P.A. Boa Sorte e Natal. Esta validação se deu em formato de entrevista na qual o entrevistado deveria responder com base em conceitos extraídos de textos técnicos, dicionários, relatórios qual o termo corresponderia ao conceito apresentado. Isto nos leva a afirmar que a análise foi do tipo semasiológica. Paralelamente a esta ação, a pesquisadora fez a leitura e análise do PPC do curso com o objetivo de observar o trabalho com a linguagem do técnico em formação, uma vez que este transita tanto no campo da linguagem técnica, quanto da linguagem comum. Observamos que o técnico deverá adaptar a linguagem ao falante, como já vem sendo praticado, no entanto, a abordagem técnica deve privilegiar a variação do termo em relação ao falante/usuário da linguagem da área.

Em relação à ocorrência das variações segundo o modelo de Faulstich (1995-2003) que considera que a variação ocorre pela ação do movimento gradual do termo no tempo e no espaço e é provocada pela função de uma dada variável. 
Encontramos a variante terminológica morfológica, a que apresenta alternância de estrutura de ordem morfológica na constituição do termo, sem que o conceito se altere, como 'gado leiteiro' e 'gado de leite', a variação atua nos formantes do termo. Esta variação se processa na substituição de uma parte do item terminológico por outro. Assim, o adjetivo 'leiteiro' se expande no sintagma preposicionado 'de leite', formado de preposição + substantivo, ou ocorre o contrário, o sintagma preposicionado se reduz a um adjetivo. O mesmo ocorre em 'ave de postura' e 'galinha poedeira', embora haja a substituição do termo 'ave' (hiperônimo) para 'galinha' (hipônimo).

A variante terminológica fonológica na qual a escrita pode surgir de formas decalcadas da fala, como em 'fel' em relação a 'feli', 'debulha' em relação a 'debuia', em que ocorre a variação marcada pela oralidade.

E a variante terminológica gráfica que se apresenta sob a forma gráfica diversificada de acordo com as convenções da língua, como 'suã' e 'suam'. Neste tipo de variação, os termos 'suã' e 'suam' são diferençados na escrita pelo uso da marca e nasalização til ( ) no primeiro formativo, e, no segundo, pela presença do arquifonema nasal, registrado com ' $n$ '. Este tipo de variação decorre da forma escrita do termo.

Diante da análise, pudemos constatar os seguintes tipos de variantes: a concorrente, a coocorrente e a competitiva, esta última em número bastante restrito, apenas duas ocorrências.

As variantes concorrentes, como já foi dito no referencial teórico, são aquelas que podem concorrer entre si, ou podem concorrer para a mudança. Nessa condição, uma variante que concorre com outra ao mesmo tempo não ocupa o mesmo espaço, por causa da própria natureza da concorrência. Tal ocorrência pode ser encontrada em 'vesícula melífera' e 'bolsa' e 'papo'. Onde na linguagem do especialista da área da apicultura, o termo 'vesícula melífera' irá ocorrer em oposição aos termos concorrentes 'bolsa' e 'papo', presentes na linguagem comum do trabalhador do campo. Esta variante é classificada por Faulstich (2002) como variante formal.

As variantes coocorrentes também se fizeram presentes e são aquelas que têm duas ou mais denominações para um mesmo referente, como por exemplo, 'mistura' e 'suplemento'; 'separador' e 'protetor'; 'mistura de raça' e 
'cruzamento'; 'frango de corte' e 'frango de granja'; 'piquete' e 'curral'; 'cruzamento' e 'cobertura'; 'mamas' e 'peitos'; 'gordura' e 'banha'. Esta variante é classificada por Faulstich (2002) como sinônimos, pois relacionam o sentido de dois ou mais termos com significados idênticos e podem coocorrer num mesmo contexto, sem que haja alteração no plano do conteúdo.

As variantes competitivas, em menor número, são aquelas que relacionam significados entre itens lexicais de línguas diferentes, quer dizer, itens lexicais de uma língua $B$ preenchem lacunas de uma língua $A$, como no exemplo, 'protetor de west', em que o formativo estrangeiro 'west' precedido da preposição 'de' forma o sintagma preposicionado 'de west' e funciona como adjetivo de 'protetor'. O formativo 'protetor de west' compete com o formativo 'isolador de rainha'. O 'protetor de west' é um tipo de equipamento/instrumento em formato de funil que protege a rainha quando esta é inserida na colmeia.

O termo de origem estrangeira, 'Langstroth', compete com o formativo 'caixa padrão Langstroth' quando há o apagamento dos dois primeiros formativos e restando apenas a designação do nome do inventor da caixa. Isso ocorre pela lei do menor esforço da língua, em que há a preferência da designação do criador e não do formativo completo.

Importa-nos afirmar que todos os termos foram analisados e são parte integrante do Glossário de Terminologias da Agropecuária, divididos em cinco subáreas e é composto de cerca de 280 termos, sendo 71 da área da apicultura, 43 da avicultura, 46 da bovinocultura, 34 da horticultura e 57 da suinocultura. Este glossário apresenta uma pequena parcela dos termos coletados junto aos assentados e poderá ser atualizado, no futuro.

O resultado desta pesquisa nos faz observar a língua de especialidade como fundamental na formação do estudante do IFTO - Campus Araguatins e que a análise empreendida aqui contribuirá com a transmissão do conhecimento formal, proporcionado pelo IFTO, com base na socioterminologia porque contempla a variação da língua de especialidade. 


\section{REFERENCIAIS BIBLIOGRÁFICOS}

BAKHTIN, M.(Volochinov). Marxismo e filosofia da linguagem: problemas fundamentais do método sociológico na ciência da linguagem. Tradução de Michel Lahud e Yara Frateschi Vieira; com a colaboração de Lúcia Teixeira Wisnik e Carlos Henrique D. Chagas Cruz. 9.ed. São Paulo: Hucitec, 1999. 196p.

BARROS, L.A. Curso Básico de Terminologia. São Paulo: Editora da USP, 2004. BIDERMAN, M.T.C. Teoria Lingüística: (teoria lexical e lingüística computacional). 2를. ed., São Paulo: Martins Fontes, 2001.

BRASIL, Decreto № 6.095, de 24 de abril de 2007. Estabelece diretrizes para fins de constituição dos Institutos Federais de Educação, Ciência e Tecnologia - IF, no âmbito da Rede Federal de Educação Tecnológica. Brasília: 2007.

BRASIL. Lei n.11.892 de 28 de dezembro de 2008, sobre a criação dos Institutos Federais de educação, Ciências e Tecnologia. Disponível em http://www.planalto.gov.br/ccivil 03/ ato 2007-2010/2008/lei/ 111892. htm>. Acesso em 28 de setembro de 2015.

BRASIL. Resolução CNE/CEB $n^{\circ} 3$ de 30 de setembro de 2009a, sobre a instituição do Sistema Nacional de Informações da Educação Profissional e Tecnológica (Sistec). Disponível em http://portal.mec.gov/dmdocuments/rceb003 09.pdf. Acesso em 28 de setembro de 2015.

BRASIL. Lei oㅜ 11.788, de 25 de setembro de 2008. Dispõe sobre o estágio de estudantes; altera a redação do art. 428 da Consolidação das Leis do Trabalho - CLT, aprovada pelo Decreto-Lei oㅜ 5.452, de 1o de maio de 1943, e a Lei no 9.394, de 20 de dezembro de 1996; revoga as Leis nos 6.494, de 7 de dezembro de 1977, e 8.859, de 23 de março de 1994, o parágrafo único do art. 82 da Lei no 9.394, de 20 de dezembro de 1996, e o art. 6o da Medida Provisória no 2.164-41, de 24 de agosto de 2001; e dá outras providências. Disponível em www.planalto.gov.br/ccivil 03/ ato20072010/2008/lei/11788.htm. Acesso em: 22. Dez 2010.

BRASIL. Lei n. 10.172, de 09 de janeiro de 2001. Aprova O Plano Nacional de Educação e dá outras providências. Disponível em http://www.planalto.gov.br/ccivil. Acesso em 28 de setembro de 2015.

BRASIL. Centenário da rede federal de educação profissional e tecnológica. Brasília: Ministério da educação, 2009b.

BRASIL. Lei n. 5.692, de 11 de agosto de 1971. Fixa as diretrizes e bases para 0 ensino de $1^{\circ}$ e $2^{\circ}$ graus, e da outras providências. Disponível em http://www.planalto.gov.br/CCIL/LEIS/L5692.html. Acesso em 28 de setembro de 2015.

BRASIL. Parecer, CNE/CBE no 39/2004.

. Parecer CNE/CBE no 11/2012. 
. Parecer CNE/CBE no 16/1999.

, Lei № 11.892/08, de 29 de dezembro de 2008. Institui a Rede Federal de Educação Profissional, Cientifica e Tecnológica, cria os Institutos Federais de Educação, Ciência e Tecnologia, e dá outras providências.

, Lei № 9.394/96, de 20 de dezembro de 1996. Lei de Diretrizes e Bases da Educação Nacional (LDB).

, Ministério da Educação. Educação Profissional e Tecnológica:

Projetos e Ações. Brasília: 2010.

. Plano de Desenvolvimento da Educação: Um novo modelo de educação profissional e tecnológica. Brasília: 2000.

- Referenciais Curriculares Nacionais da Educação Profissional de Nível Técnico. Brasília: 2000.

, PARECER CNE/CEB no 17/97. Estabelece as diretrizes operacionais para a educação profissional em nível nacional. Brasília, 03 de dezembro de 1997.

CABRÉ, M.T. Lexicologia y variación: hacia um modelo integrado. In: Actas Del Simpósio Iberoamericano de Terminologia: Terminologia, Ciência y Tecnología, Ciudad de México, Del 3 al 8 de noviembre de 1996. Paris: União Latina. P.1-8, 1996.

Metodológicos". In:

"Una Nueva Teoria de la terminologia: Aspectos Cominación. Barcelona, IULA. pp. 109-127, 1999.

. La terminología: teoria, metodologia, aplicaciones. Barcelona:

Espanha, Antartida/Empuries, 1993.

Norma y Normas em Terminología: Concepto, Tipología y Justificación. In: Isquerdo, A. N. e Finatto, M. J. B. As Ciências do Léxico: lexicologia, lexicografia, terminologia - volume IV. Campo Grande, MS: ED. UFMS ; Porto Alegre: Editora da UFRGS, 2010.

CNI. Confederação Nacional das Indústrias. Estatística. Disponível em www.cni.org.br. Acesso em 03.06.2012

CORDÃO, F. A. Educação Geral e Formação Profissional na Ótica das Competências, 2010. In: REGATTIERI, M. (org). Ensino Médio e Educação Profissional: Desafios da Integração. 2ª ed. Brasília: UNESCO, MEC, 2010.

- Desafios das Diretrizes Curriculares Nacionais Para A Educação Profissional. B. Tec. Senac, Rio de Janeiro, v. 39, n.2, p.26-47, maio/ago. 2013.

CRUZ, C. L. S. Estudo da Terminologia das Fibras e Tecidos na Área Têxtil. Dissertação (Mestrado em Linguística) - Instituto de Letras - Departamento de 
Linguística, Línguas Clássicas e Vernácula, Universidade de Brasília, Distrito Federal, . 2005. 150f.

Dicionário da Educação Profissional em Saúde. Fundação Oswaldo Cruz. Escola Politécnica de Saúde Joaquim Venâncio.- Manguinhos - Rio de Janeiro - RJ. Disponível em <http://www.epsjv.fiocruz.br/dicionario/> Acesso em, 19/01/2016.

FAULSTICH, E. Base metodológica para pesquisa em socioterminologia: termo e variação. Brasília: Centro Lexterm, 1995. 31p.

.Aspectos de terminologia geral e terminologia variacionista. TradTerm: Revista do Centro Interdepartamental de Traducão e Terminologia - Faculdade de Filosofia, Letras e Ciências Humanas - V.7 USP. Sao Paulo: Humanitas, 2001.

- Socioterminologia, mais que um método de pesquisa, uma disciplina. Ciência da Informação, vol. 24, n.2, 1995 - Artigos. 1996, pp. 281-288.

Ciência da Comunicação, MCT/CNPq/IBICT, Brasília (24), n.3,

- Variantes terminológicas: princípios linguísticos de análise e método de recolha. Actes Réflexions Méthodologiques sur le Travail em Terminologie et en Terminotique dans les Langues Latines. Realiter, Université de Nice-Sophie Antipolis, Nice, 1996, pp. 15-19.

Recife: UFP, 1997.

Da linguística histórica à terminologia. Investigações, vol. 7, - Princípios formais e funcionais de variação em terminologia. Seminário de Terminologia Teórica, Barcelona, 28-29 de janeiro, 1999.

Aspectos de terminologia geral e terminologia variacionista. TradTerm: Revista do Centro Interdepartamental de Tradução e Terminologia - Faculdade de Filosofia, Letras e Ciências Humanas - V.7 USP. São Paulo: Humanitas, 2001.

. Variação em terminologia. Aspectos de socioterminologia. In. Ramos, G. G. e Lagos, M. F. P. Panorama actual de la terminologia. Editorial Comares, Granada, 2002.

. Formação de termos: do constructo e das regras às evidências empíricas. In. Faulstich, E. e Abreu, S. P. Linguística aplicada à terminologia e à lexicologia - Cooperação Brasil e Canadá. Porto Alegre: UFRGS, Instituto de Letras, NEC, 2003.

: Para que serve um livro didático de Língua Portuguesa?. In. Faustich, E. Universidade de Brasília - Brasília distrito Federal. Educação 08 de maio de 2011.

FÁVERO, M.L.A. A Universidade no Brasil: das origens à Reforma Universitária de 1968. Educar, Curitiba, n.28, p. 17-36, Maio/Jun. 2006. 
FINATTO, M. J. B. Unidade e variação na língua portuguesa: a variação em terminologia. In. Krieger, M. T. e Maciel, A. M. B. Temas de terminologia. Porto Alegre/São Paulo: Ed. Universidade/UFRGS/Humanitas/USP, 2001.

Unidade e variação na língua portuguesa: a variação em Terminologia. Revista Internacional de Língua Portuguesa. Lisboa: Associação das Universidades de Língua Portuguesa, 1996, p. 64-68.

FRIGOTTO, G. Estrutura e sujeito e os fundamentos da relação trabalho e educação. In: LOMBARDI, J. C, SAVIANI, D. e SANFELICE, J. (Org.). Capitalismo, trabalho e educação. 2 ed. Campinas SP: Autores Associados, 2004.

FRIGOTTO, Gaudêncio, CIAVATTA, Maria; RAMOS, Marise. A gênese do decreto n. 5.154/2004: um debate no contexto controverso da democracia restrita. In FRIGOTTO, G.: CIAVATTA, M.: RAMOS, M. (org). Ensino Médio integrado: concepção e contradições. São Paulo: Cortez, 2005, p.21-56.

FREITAG, Bárbara. Escola, Estado \& Sociedade. $7^{\circ}$ ed. São Paulo: Centauro, 2005.

GERMANO, J. W., Estado Militar e Educação no Brasil (1964-1985). 4.ed. São Paulo:

Cortez, 2005.

Giambiagi, F., Villela, A., Barros de Castro, L., \& Hermann, J. (orgs.) (2005). Economia Brasileira Contemporânea. Campus, Rio de Janeiro.

IFTO, Instituto Federal do Tocantins. Instruções Normativas no 04/2010 e 09/2011.

IBGE. Dados estatísticos: cidades. Disponível em: <www.ibge.gov.br>. Acessado em 22 de outubro de 2015.

JAKOBSON, R. Linguística e comunicação. São Paulo Cultrix, 1969.

KUENZER, Acácia Z. Ensino Médio: Construindo uma proposta para os que vivem do trabalho. São Paulo: Cortez, 2002.

KRIEGER, M. T. O termo: questionamentos e configurações. In: Kriger, M. T. e Maciel, A. M. B. Temas de Terminologia. Porto Alegre/São Paulo: Editora Universidade/UFRGS/Humanitas/USP, 2001.

e MACIEL, A. M. B. Temas de Terminologia. Porto Alegre/São Paulo: Editora Universidade/UFRGS/Humanitas/USP, 2001.

LAFACE, A. Vocábulo básico de áreas disciplinares - contexto terminológico e processo pedagógico. Simpósio de RITERM, 1998.

LÜDKE, M. e ANDRÉ, M. E. D. A. Pesquisa em Educação: abordagens qualitativas. São Paulo: EPU, 1986. p.99.

MACIEL, A. M. B. Quais são os Rumos da Terminologia no Século XXI? In: Isquerdo, A. N. e Alves, I. M. As Ciências do Léxico: lexicologia, lexicografia, 
terminologia, volume III. Campo Grande, MS: Ed. UFMS; São Paulo : Humanitas, 2007.

MANACORDA, M. A. Marx e a Pedagogia Moderna. São Paulo: Cortez. Autores Associados, 1991.

MARTINS, H.T. Gestão de carreiras na era do conhecimento: abordagem conceitual e resultados de pesquisa. Rio de Janeiro: Qualitymark, 2001.

MARCUSCH, L. A. O Papel da Linguística no Ensino de Línguas (UFPE/CNPQ-2002) Universidade Federal de Pernambuco, Departamento de Letras, Programa de Pós- Graduação de Letras e Linguística.

MOREIRA, A F. B. Educação Escolar e Cultura (s): construindo caminhos. In: FÁVERO, Osmar, (org). Educação Como Exercício de Diversidade. Brasília: UNESCO, MEC, ANPed, 2007.

MOURA, Dante Henrique. A Relação entre a educação profissional e a educação básica CONAE 2010: possibilidades e limites para a construção do novo Plano Nacional de Educação. Educ. Soc., Campinas, v. 31, n. 112, p. 875-894, jul.-set. 2010.

NDR. Núcleo de Desenvolvimento Regional. Dados Estatísticos UFT. 2010

PROJETO PEDAGÓGICO DO CURSO TÉCNICO DE AGROPECUÁRIA INTEGRADO. IFTO Campus Araguatins, 2013.

RICHARDSON, R. J. Pesquisa Social: métodos e técnicas.3a ed. São Paulo. Atlas, 1999.

RESOLUÇÃO № 01 da Coordenação do Programa de Mestrado Profissional em Educação - Modalidade Profissional. Estabelece as regras para Elaboração do Trabalho Final no âmbito do Mestrado em Educação do PPGE-MP. Brasília, 2014.

SCHERRE, M. O preconceito linguístico deveria ser crime. In, AUTOR, Scherre, M. Revista Galileu. Editora: Globo S/A, 2013. Disponível em $<$ http://revistagalileu.globo.com/Revista/Common/0,EMl110515-17774,00-

O+PRECONCEITO+LINGUISTICO+DEVERIA+SER+CRIME.html> Acessado em, 15 de julho de 2016.

SAVIANI, D. Sobre a concepção de politecnia. Rio de Janeiro: Fundação Oswaldo Cruz, 1989.

SECRETARIA DE EDUCAÇÃO PROFISSIONAL E TECNOLÓGICA. PROJETO INSTITUCIONAL: Transformação da ETF-Palmas e EAFA em Instituto Federal de Educação, Ciência e Tecnologia - IFET - Tocantins. Palmas-TO, 2008.

WÜSTER, E. (1979) Introducción a la Teoria General de la Terminología y a la Lexicografia Termonilógica. Trad. de A. Nokerman. Barcelona: Institut Universitari de Lingüística Aplicada/Universitat Pompeu Fabra, 1998. 
TIMBANE, A. A. A Variação Terminológica dos Termos de Futebol Moçambicano. In: Murakama, C. A. A. e Nadin, O. L. Terminologia: uma ciência Interdisciplinar. São Paulo: Cultura Acadêmica, 2013. 


\section{ANEXO 1 - QUESTIONÁRIOS}

Araguatins/TO 07 de junho de 2015

Prezado (a) Agropecuarista

Como mestranda em Políticas Públicas e Gestão da Educação Profissional e Tecnológica pela UnB, CPF 019-702-534-01, estou desenvolvendo uma pesquisa que tem como proposta a análise socioterminológica que investiga a variação dos termos da área da Agropecuária em situação de uso, tanto pelos técnicos, como pelos agropecuaristas que habitam a microrregião do Bico do Papagaio do Tocantins.

Desta forma, Você está convidado (a) a colaborar de forma voluntária com esta pesquisa. Para isso foi criado um questionário com perguntas específicas dividido em subáreas e este refere-se à Apicultura que faz parte da coleta de dados da referida pesquisa "O Papel do Técnico em Agropecuária: entre 0 Léxico Específico e o Léxico Comum. Sob minha responsabilidade, Profa. Mestranda Maria Betânia Rodrigues de Menezes telefone: (87) 99620-3315 da $\mathrm{Fe} /$ UnB Universidade de Brasília. As respostas a essas questões não terão nenhuma interferência ou questionamento de minha parte. Sua participação não trará nenhum benefício direto a você, mas poderá proporcionar um maior conhecimento sobre 0 assunto que está sendo pesquisado, o que poderá beneficiar outras pessoas no futuro. Não existirão despesas ou compensações pessoais para nenhum participante em qualquer fase do estudo, e não há compensação financeira relacionada à sua participação.

Caso você concorde em participar da pesquisa, leia com atenção os seguintes pontos: a) você é livre para, a qualquer momento, recusar-se a responder às perguntas que the ocasionem constrangimento de qualquer natureza; b) você pode deixar de participar da pesquisa e não precisa apresentar justificativas para isso; c) sua identidade será mantida em sigilo; d) caso você queira, poderá ser informado(a) de todos os resultados obtidos com a pesquisa, independentemente do fato de mudar seu consentimento em participar da pesquisa.

Eu me comprometo a utilizar os dados coletados somente para pesquisa e os resultados deverão ser veiculados por meio de artigos científicos em revistas especializadas e /ou em encontros científicos e congressos, sem nunca tornar possível sua identificação.

Anexo está o consentimento livre e esclarecido para ser assinado caso não tenha ficado qualquer dúvida e você concorde em participar.

Agradeço, antecipadamente, sua participação nesta pesquisa. 


\section{TERMO DE CONSENTIMENTO LIVRE E ESCLARECIDO}

Acredito ter suficientemente informação a respeito do estudo sobre $\mathbf{O}$ Papel do Técnico em Agropecuária: entre o Léxico Especializado e o Léxico Comum. Ficaram claros os procedimentos a serem realizadas e a garantia de que minha participação é isenta de despesas, além do meu acesso aos resultados obtidos.

Concordo voluntariamente em participar deste estudo, sabendo que poderei retirar meu consentimento a qualquer momento, antes ou durante o mesmo, sem penalidades, prejuízos ou perda de qualquer benefício que eu possa ter adquirido anteriormente ao estudo.

\section{( ) CONCORDO EM PARTICIPAR VOLUNTARIAMENTE DO ESTUDO}

Favor marcar um x no parêntese.

Nome do entrevistado

Endereço:

Fone:

E-mail:

\section{QUESTIONÁRIO PARA PESQUISA SOBRE O LÉXICO ESPECÍFICO E O LÉXICO COMUM DA APICULTURA, NA MICRORREGIÃO DO BICO DO PAPAGAIO.}

1) São políbridos resultantes dos cruzamentos entre as abelhas-africanas (Apis mellifera scutellata), e as raças europeias(Apis mellifera mellifera, Apis mellifera ligustica, Apis mellifera carnica, Apis mellifera caucasica), que foram introduzidas na Américaantes da chegada das africanas em1956, predominando, nestes políbridos, as características morfológicas e comportamentais das africanas.O senhor (a) conhece por? 


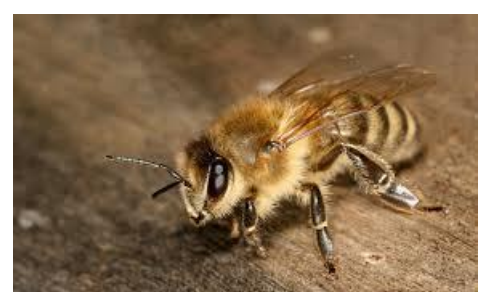

( ) Abelhas Africanizadas ( )Abelhas Italianas ( ) Oropa ( ) Outros

2) Qual o termo usado para o conjunto de colmeias, utilizadas para criação de abelhas, normalmente para a colheita de mel ou a polinização de culturas agrícolas?

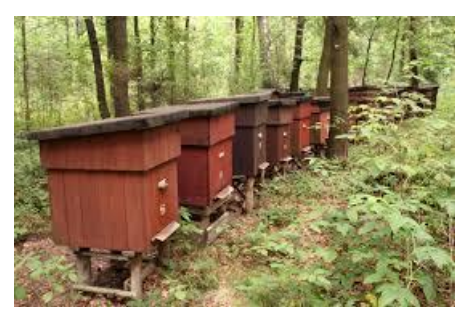

( ) Apiário ( ) Cortiço ( ) Outros

3) Lugar destinado a cria, produção de produtos naturais por meio das abelhas e reprodução de seres de sua mesma espécie, além de servir como morada. Por como o Senhor (a) conhece esse conceito?

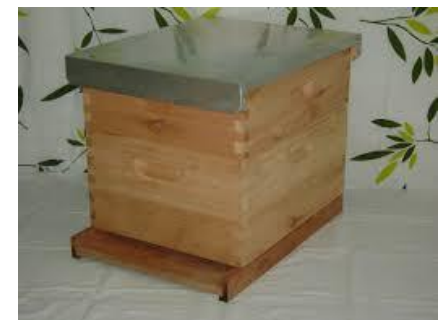

\section{( ) Caixa Móvel}

( ) Caixopa

( ) Colmeia

Outros

4) Qual o termo utilizado para a lâmina de cera de abelha prensada, que apresenta, de ambos os lados, o relevo de um hexágono do mesmo tamanho do alvéolo, que servirá de guia para a construção dos alvéolos dos favos?

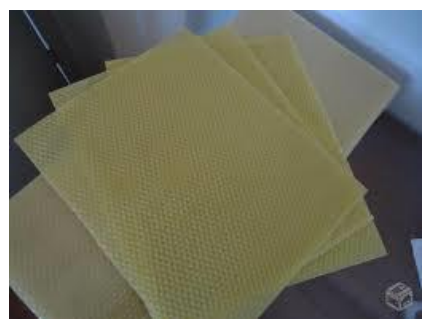

( ) Cera alveolada ( ) Cera prensada ( ) Outros

5) Como é conhecida a arma de defesa das abelhas, onde as mesmas injetam uma toxina que, em grandes doses pode ser fatal? 


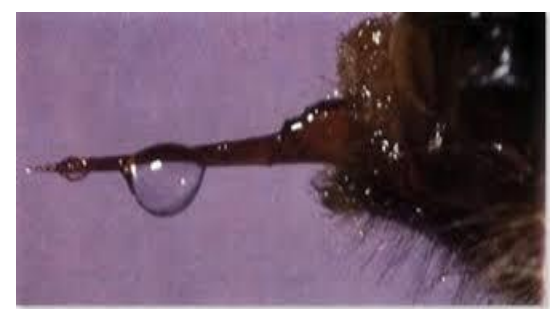

( ) Ferrão ( ) Esporão （）Outros

6) Como o Senhor (a) conhece o equipamento constituído de tampa, fole, fornalha, grelha e bico de pato que tem a função de produzir fumaça, sendo essencial para um manejo seguro?

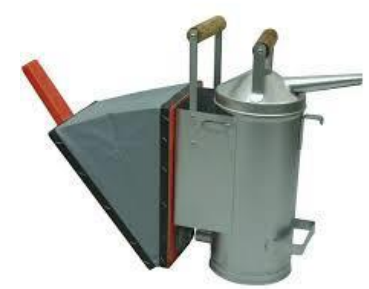

( ) Fumigador

( ) Fumaceiro

( ) Outros 
Prezado (a) Agropecuarista

Como mestranda em Políticas Públicas e Gestão da Educação Profissional e Tecnológica pela UnB, CPF 019-702-534-01, estou desenvolvendo uma pesquisa que tem como proposta a análise socioterminológica que investiga a variação dos termos da área da Agropecuária em situação de uso, tanto pelos técnicos, como pelos agropecuaristas que habitam a microrregião do Bico do Papagaio do Tocantins.

Desta forma, Você está convidado (a) a colaborar de forma voluntária com esta pesquisa. Para isso foi criado um questionário com perguntas específicas dividido em subáreas e este refere-se a Aves de Corte e Postura que faz parte da coleta de dados da referida pesquisa "O Papel do Técnico em Agropecuária: entre o Léxico Específico e o Léxico Comum. Sob minha responsabilidade, Profa. Mestranda Maria Betânia Rodrigues de Menezes telefone: (87) 99620-3315 da Fe/UnB Universidade de Brasília. As respostas a essas questões não terão nenhuma interferência ou questionamento de minha parte. Sua participação não trará nenhum benefício direto a você, mas poderá proporcionar um maior conhecimento sobre o assunto que está sendo pesquisado, o que poderá beneficiar outras pessoas no futuro. Não existirão despesas ou compensações pessoais para nenhum participante em qualquer fase do estudo, e não há compensação financeira relacionada à sua participação.

Caso você concorde em participar da pesquisa, leia com atenção os seguintes pontos: a) você é livre para, a qualquer momento, recusar-se a responder às perguntas que lhe ocasionem constrangimento de qualquer natureza; b) você pode deixar de participar da pesquisa e não precisa apresentar justificativas para isso; c) sua identidade será mantida em sigilo; d) caso você queira, poderá ser informado(a) de todos os resultados obtidos com a pesquisa, independentemente do fato de mudar seu consentimento em participar da pesquisa.

Eu me comprometo a utilizar os dados coletados somente para pesquisa e os resultados deverão ser veiculados por meio de artigos científicos em revistas especializadas e lou em encontros científicos e congressos, sem nunca tornar possível sua identificação.

Anexo está o consentimento livre e esclarecido para ser assinado caso não tenha ficado qualquer dúvida e você concorde em participar.

Agradeço, antecipadamente, sua participação nesta pesquisa. 


\section{TERMO DE CONSENTIMENTO LIVRE E ESCLARECIDO}

Acredito ter suficientemente informação a respeito do estudo sobre 0 Papel do Técnico em Agropecuária: entre o Léxico Especializado e o Léxico Comum. Ficaram claros os procedimentos a serem realizadas e a garantia de que minha participação é isenta de despesas, além do meu acesso aos resultados obtidos.

Concordo voluntariamente em participar deste estudo, sabendo que poderei retirar meu consentimento a qualquer momento, antes ou durante o mesmo, sem penalidades, prejuízos ou perda de qualquer benefício que eu possa ter adquirido anteriormente ao estudo.

\section{( ) CONCORDO EM PARTICIPAR VOLUNTARIAMENTE DO ESTUDO}

Favor marcar um x no parêntese.

Nome do entrevistado

Endereço:

Fone:

E-mail:

\section{QUESTIONÁRIO PARA PESQUISA SOBRE O LÉXICO ESPECÍFICO E O LÉXICO COMUM DA AVICULTURA, NA MICRORREGIÃO DO BICO DO} PAPAGAIO.

1- Construção constituída de cobertura de telha ou palha, desprovido de paredes laterais, utilizado para o abrigo e confinamento de aves. O senhor (a) conhece por?

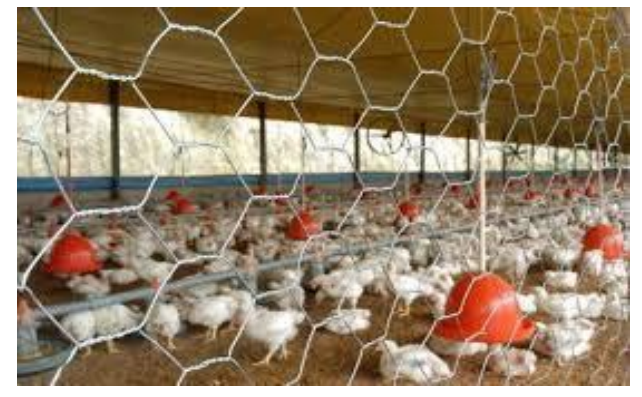

（）Galpão aviário ( ) Aviário （）Poleiro （）Galinheiro ( ) Outros

2- São aves confinadas destinadas à produção de ovos, sendo este considerado de alto valor nutricional, podendo a sua qualidade ser influenciada por fatores como condições de manejo, instalações, nutrição e ambiente. O senhor (a) conhece por? 


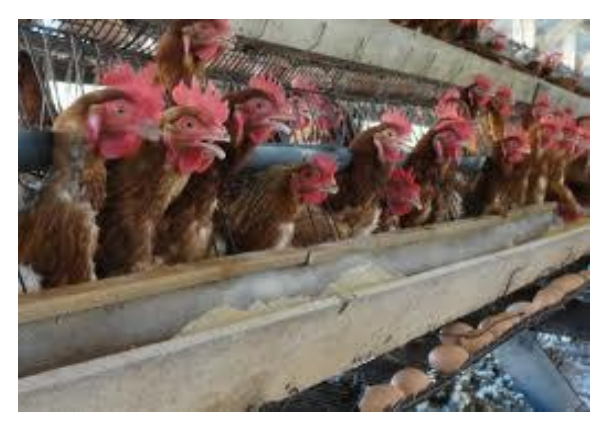

( ) Aves de postura ( ) Galinha poedeira ( ) Outros

3- Como o Senhor (a) conhece a ave que tem, como característica, rusticidade e resistência, sendo fáceis de manejar, embora não sejam boas chocadeiras?

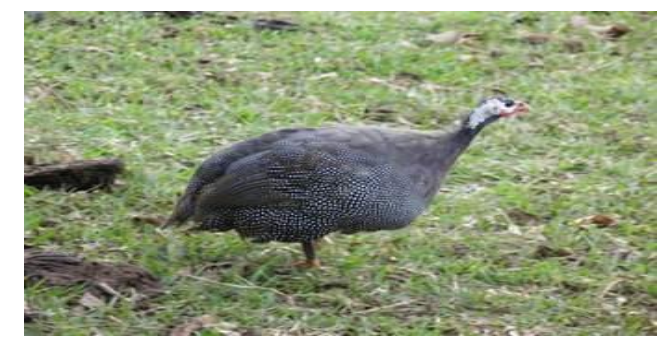

( ) Galinha d'angola ( ) Capote ( ) Angolista ( ) Outros 
Prezado (a) Agropecuarista

Como mestranda em Políticas Públicas e Gestão da Educação Profissional e Tecnológica pela UnB, CPF 019-702-534-01, estou desenvolvendo uma pesquisa que tem como proposta a análise socioterminológica que investiga a variação dos termos da área da Agropecuária em situação de uso, tanto pelos técnicos, como pelos agropecuaristas que habitam a microrregião do Bico do Papagaio do Tocantins.

Desta forma, Você está convidado (a) a colaborar de forma voluntária com esta pesquisa. Para isso foi criado um questionário com perguntas específicas dividido em subáreas e este se refere à Bovinocultura que faz parte da coleta de dados da referida pesquisa "O Papel do Técnico em Agropecuária: entre o Léxico Específico e - Léxico Comum". Sob minha responsabilidade, Profa. Mestranda Maria Betânia Rodrigues de Menezes telefone: (87) 99620-3315 da Fe/UnB Universidade de Brasília. As respostas a essas questões não terão nenhuma interferência ou questionamento de minha parte. Sua participação não trará nenhum benefício direto a você, mas poderá proporcionar um maior conhecimento sobre o assunto que está sendo pesquisado, o que poderá beneficiar outras pessoas no futuro. Não existirão despesas ou compensações pessoais para nenhum participante em qualquer fase do estudo, e não há compensação financeira relacionada à sua participação.

Caso você concorde em participar da pesquisa, leia com atenção os seguintes pontos: a) você é livre para, a qualquer momento, recusar-se a responder às perguntas que lhe ocasionem constrangimento de qualquer natureza; b) você pode deixar de participar da pesquisa e não precisa apresentar justificativas para isso; c) sua identidade será mantida em sigilo; d) caso você queira, poderá ser informado(a) de todos os resultados obtidos com a pesquisa, independentemente do fato de mudar seu consentimento em participar da pesquisa.

Eu me comprometo a utilizar os dados coletados somente para pesquisa e os resultados deverão ser veiculados por meio de artigos científicos em revistas especializadas e lou em encontros científicos e congressos, sem nunca tornar possível sua identificação.

Anexo está o consentimento livre e esclarecido para ser assinado caso não tenha ficado qualquer dúvida e você concorde em participar.

Agradeço, antecipadamente, sua participação nesta pesquisa. 


\section{TERMO DE CONSENTIMENTO LIVRE E ESCLARECIDO}

Acredito ter suficientemente informação a respeito do estudo sobre 0 Papel do Técnico em Agropecuária: entre o Léxico Especializado e o Léxico Comum. Ficaram claros os procedimentos a serem realizadas e a garantia de que minha participação é isenta de despesas, além do meu acesso aos resultados obtidos.

Concordo voluntariamente em participar deste estudo, sabendo que poderei retirar meu consentimento a qualquer momento, antes ou durante o mesmo, sem penalidades, prejuízos ou perda de qualquer benefício que eu possa ter adquirido anteriormente ao estudo.

\section{( ) CONCORDO EM PARTICIPAR VOLUNTARIAMENTE DO ESTUDO}

Favor marcar um x no parêntese.

Nome do entrevistado

Endereço:

Fone:

E-mail:

\section{QUESTIONÁRIO PARA PESQUISA DO LÉXICO ESPECÍFICO E O LÉXICO COMUM DA BOVINOCULTURA, NA MICRORREGIÃO DO BICO DO PAPAGAIO.}

1- Líquido com uma consistência espessa e cor amarela ou transparente, segregado pela glândula mamária durante o período final da gravidez e os primeiros dias depois do parto e, apesar de ser produzido em pequena quantidade, tem na sua composição todos os nutrientes necessários para alimentar adequadamente $o$ animal recém-nascido. O que o senhor (a) entende por?

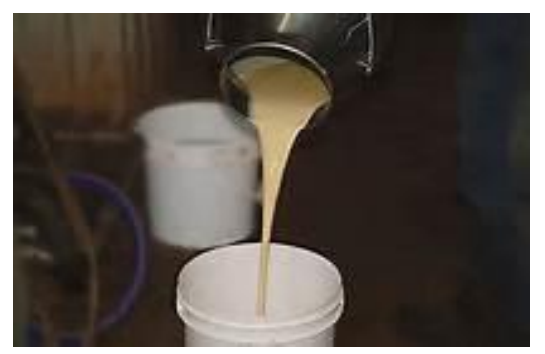

( ) Colostro

( ) Leite sujo

( ) Outros

2- Conjunto de práticas sistemáticas e necessárias para a cria, recria e engorda do rebanho, desde o primeiros dias de vida até o carregamento para o abatedouro. 


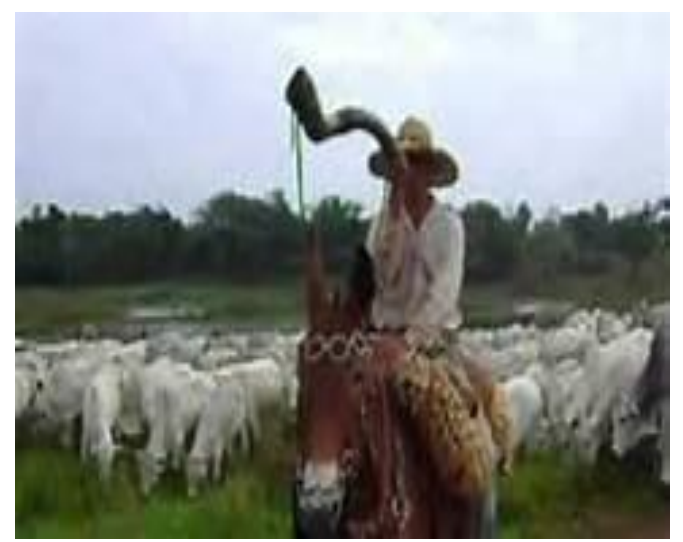

( ) Manejo ( ) Serviços ( ) Cuidados ( ) Outros

3-Tempo de desenvolvimento do embrião no útero, desde a concepção até o nascimento, tendo como tempo de duração 284 dias aproximadamente. Por qual termo o Senhor( a ) conhece?

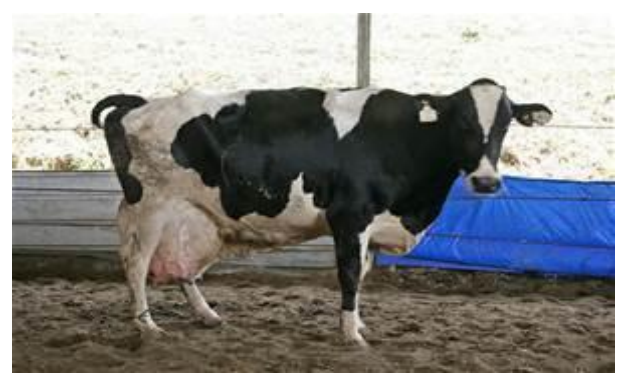

( ) Gestante( ) Prenha ( ) Mojada ( ) Outros 
Prezado (a) Agropecuarista

Como mestranda em Políticas Públicas e Gestão da Educação Profissional e Tecnológica pela UnB, CPF 019-702-534-01, estou desenvolvendo uma pesquisa que tem como proposta a análise socioterminológica que investiga a variação dos termos da área da Agropecuária em situação de uso, tanto pelos técnicos, como pelos agropecuaristas que habitam a microrregião do Bico do Papagaio do Tocantins.

Desta forma, Você está convidado (a) a colaborar de forma voluntária com esta pesquisa. Para isso foi criado um questionário com perguntas específicas dividido em subáreas e este se refere à Suinocultura que faz parte da coleta de dados da referida pesquisa "O Papel do Técnico em Agropecuária: entre o Léxico Específico e - Léxico Comum". Sob minha responsabilidade, Profa. Mestranda Maria Betânia Rodrigues de Menezes telefone: (87) 99620-3315 da Fe/UnB Universidade de Brasília. As respostas a essas questões não terão nenhuma interferência ou questionamento de minha parte. Sua participação não trará nenhum benefício direto a você, mas poderá proporcionar um maior conhecimento sobre o assunto que está sendo pesquisado, o que poderá beneficiar outras pessoas no futuro. Não existirão despesas ou compensações pessoais para nenhum participante em qualquer fase do estudo, e não há compensação financeira relacionada à sua participação.

Caso você concorde em participar da pesquisa, leia com atenção os seguintes pontos: a) você é livre para, a qualquer momento, recusar-se a responder às perguntas que the ocasionem constrangimento de qualquer natureza; b) você pode deixar de participar da pesquisa e não precisa apresentar justificativas para isso; c) sua identidade será mantida em sigilo; d) caso você queira, poderá ser informado(a) de todos os resultados obtidos com a pesquisa, independentemente do fato de mudar seu consentimento em participar da pesquisa.

Eu me comprometo a utilizar os dados coletados somente para pesquisa e os resultados deverão ser veiculados por meio de artigos científicos em revistas especializadas e lou em encontros científicos e congressos, sem nunca tornar possível sua identificação.

Anexo está o consentimento livre e esclarecido para ser assinado caso não tenha ficado qualquer dúvida e você concorde em participar.

Agradeço, antecipadamente, sua participação nesta pesquisa 


\section{TERMO DE CONSENTIMENTO LIVRE E ESCLARECIDO}

Acredito ter suficientemente informação a respeito do estudo sobre 0 Papel do Técnico em Agropecuária: entre o Léxico Especializado e o Léxico Comum. Ficaram claros os procedimentos a serem realizadas e a garantia de que minha participação é isenta de despesas, além do meu acesso aos resultados obtidos.

Concordo voluntariamente em participar deste estudo, sabendo que poderei retirar meu consentimento a qualquer momento, antes ou durante o mesmo, sem penalidades, prejuízos ou perda de qualquer benefício que eu possa ter adquirido anteriormente ao estudo.

\section{（ ) CONCORDO EM PARTICIPAR VOLUNTARIAMENTE DO ESTUDO}

Favor marcar um x no parêntese.

Nome do entrevistado

Endereço:

Fone:

E-mail:

\section{QUESTIONÁRIO PARA PESQUISA DO LÉXICO ESPECÍFICO E O LÉXICO COMUM DA SUINOCULTURA, NA MICRORREGIÃO DO BICO DO PAPAGAIO.}

1- São fêmeas desmamadas que ainda não iniciaram seu ciclo de reprodução, animais jovens que se tornarão primíparas (primeira cria) logo mais a frente. $O$ senhor (a) entende por?

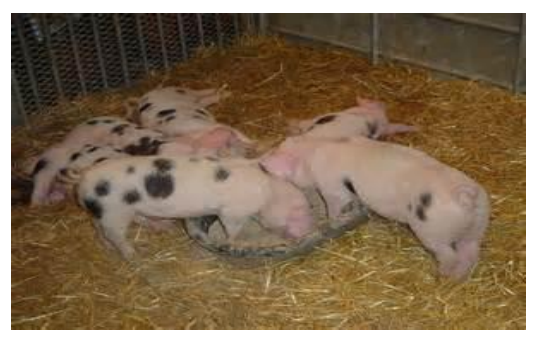

( ) Marrã （）Leitoa virgem （ )Porca virgem （）Outros

2 - Animal ligeiramente robusto e não castrado, responsável pela monto-a da fêmea e reprodução da espécie. O senhor (a) conhece por? 


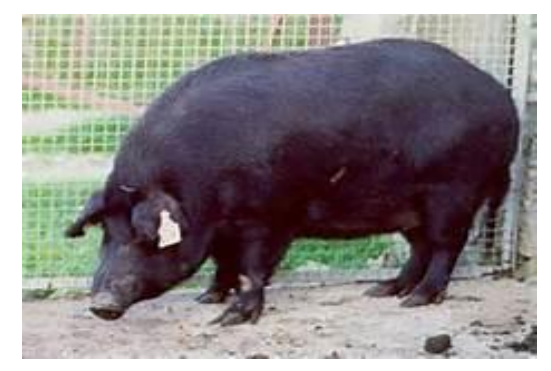
( ) Cachaço
( ) Barrão
( ) Varrão
( ) Outros

3 - Por definição é o período em que a fêmea aceita a monta, ou, o período em que ela fica parada, enquanto outro animal salta sobre ela. É um fenômeno fisiológico caracterizado principalmente pelas mudanças no seu comportamento. Como o senhor (a) intitula esse conceito?

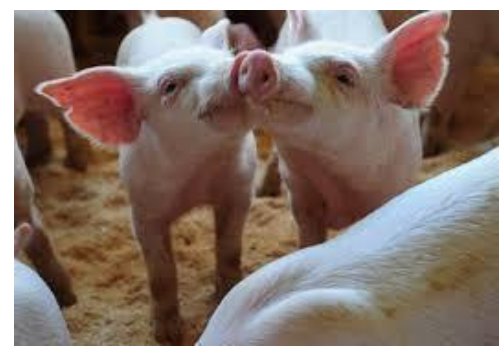

( ) Cio ( ) Viço

( ) Outros 
Prezado (a) Agropecuarista

Como mestranda em Políticas Públicas e Gestão da Educação Profissional e Tecnológica pela UnB, CPF 019-702-534-01, estou desenvolvendo uma pesquisa que tem como proposta a análise socioterminológica que investiga a variação dos termos da área da Agropecuária em situação de uso, tanto pelos técnicos, como pelos agropecuaristas que habitam a microrregião do Bico do Papagaio do Tocantins.

Desta forma, Você está convidado (a) a colaborar de forma voluntária com esta pesquisa. Para isso foi criado um questionário com perguntas específicas dividido em subáreas e este se refere à Olericultura (Horticultura) que faz parte da coleta de dados da referida pesquisa "O Papel do Técnico em Agropecuária: entre o Léxico Específico e o Léxico Comum". Sob minha responsabilidade, Profa. Mestranda Maria Betânia Rodrigues de Menezes telefone: (87) 99620-3315 da Fe/UnB Universidade de Brasília. As respostas a essas questões não terão nenhuma interferência ou questionamento de minha parte. Sua participação não trará nenhum benefício direto a você, mas poderá proporcionar um maior conhecimento sobre o assunto que está sendo pesquisado, o que poderá beneficiar outras pessoas no futuro. Não existirão despesas ou compensações pessoais para nenhum participante em qualquer fase do estudo, e não há compensação financeira relacionada à sua participação.

Caso você concorde em participar da pesquisa, leia com atenção os seguintes pontos: a) você é livre para, a qualquer momento, recusar-se a responder às perguntas que Ihe ocasionem constrangimento de qualquer natureza; b) você pode deixar de participar da pesquisa e não precisa apresentar justificativas para isso; c) sua identidade será mantida em sigilo; d) caso você queira, poderá ser informado(a) de todos os resultados obtidos com a pesquisa, independentemente do fato de mudar seu consentimento em participar da pesquisa.

Eu me comprometo a utilizar os dados coletados somente para pesquisa e os resultados deverão ser veiculados por meio de artigos científicos em revistas especializadas e lou em encontros científicos e congressos, sem nunca tornar possível sua identificação.

Anexo está o consentimento livre e esclarecido para ser assinado caso não tenha ficado qualquer dúvida e você concorde em participar.

Agradeço, antecipadamente, sua participação nesta pesquisa 


\section{TERMO DE CONSENTIMENTO LIVRE E ESCLARECIDO}

Acredito ter suficientemente informação a respeito do estudo sobre 0 Papel do Técnico em Agropecuária: entre o Léxico Especializado e o Léxico Comum. Ficaram claros os procedimentos a serem realizadas e a garantia de que minha participação é isenta de despesas, além do meu acesso aos resultados obtidos.

Concordo voluntariamente em participar deste estudo, sabendo que poderei retirar meu consentimento a qualquer momento, antes ou durante o mesmo, sem penalidades, prejuízos ou perda de qualquer benefício que eu possa ter adquirido anteriormente ao estudo.

\section{( ) CONCORDO EM PARTICIPAR VOLUNTARIAMENTE DO ESTUDO}

\section{Favor marcar um x no parêntese.}

Nome do entrevistado

Endereço:

Fone:

E-mail:

QUESTIONÁRIO PARA PESQUISA SOBRE O LÉXICO ESPECÍFICO E O LÉXICO COMUM DA OLERICULTURA/ HORTICULTURA NA MICRORREGIÃO DO BICO DO PAPAGAIO

1- É definida como uma escavação linear caracterizada por apresentar profundidade maior que a largura, escavação longa e mais ou menos estreita na extremidade de um terreno, para escoamento das águas pluviais. O Senhor (a) conhece essa definição por?

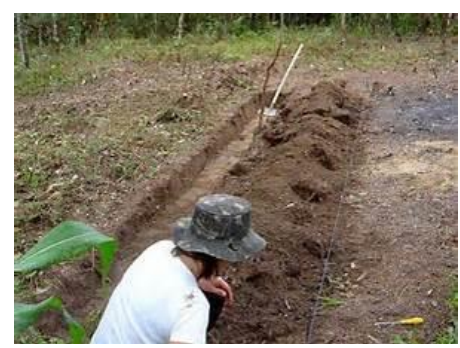

( )Canal ( )Vala ( )Rego ( )Outros

2 - É uma das etapas mais difíceis e importantes para a vida de uma planta, se refere exatamente ao período em que há a quebra da dormência da semente e esta inicia seu desenvolvimento. Seria algo semelhante para nós ao período gestacional, uma vez que se necessita de cuidados e condições especiais. O 
Senhor (a) conhece como sendo?

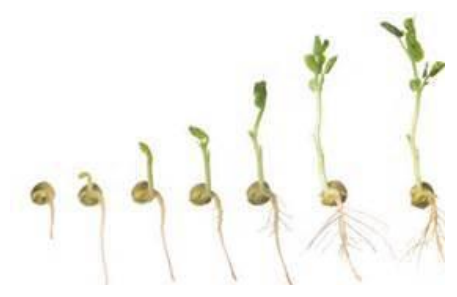

（ ) Germinação ( ) Emergência ( ) Nascimento ( ) Brotação ( ) Outros

3 - Produção agrícola de vários tipos de produtos. Está associada aos minifúndios. Sistema de exploração do solo, que consiste em obter vários tipos de produtos numa mesma propriedade, numa mesma região. O Senhor (a) entende por?

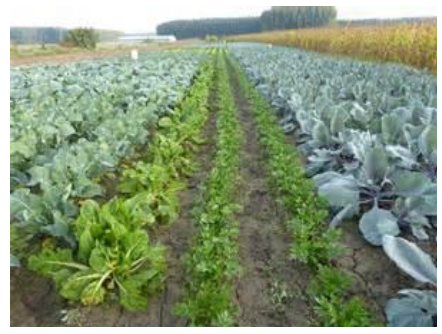

( ) Policultivo ( ) Associação ( ) Roça Misturada ( ) Outros 
ANEXO 2 - LISTA DOS TERMOS VARIANTES

\begin{tabular}{|c|c|}
\hline \multicolumn{2}{|c|}{ APICULTURA } \\
\hline LÉXICO ESPECIALIZADO & LÉXICO сOMUM \\
\hline ABELHAS AFRICANIZADAS & ABELHAS ITALIANAS / OROPA \\
\hline APIÁRIO & CORTIÇO / ABELHEIRO / CRIATÓRIO \\
\hline MOBILISTA / COLMEIA & CAIXOTE / CAIXA MÓVEL / MORADA \\
\hline CERA ALVEOLADA & CERA PRENSADA / FABRICADA \\
\hline FERRÃO & ESPORÃO \\
\hline FUMIGADOR & FUMACEIRO / BOTADOR DE FUMAÇA \\
\hline NÉCTAR & MEL DA FLOR / AÇUCAR DA FLOR \\
\hline OCELOS & OLHOS PRIMITVOS / OLHOS PEQUENOS \\
\hline VESÍCULA MELIFERA & BOLSA / PAPO \\
\hline ALVADO & PORTA / ENTRADA DA CAIXA \\
\hline ALVÉOLO & DEPÓSITO / FAVO DE CRIA / MEL \\
\hline $\begin{array}{l}\text { EPI (EQUIPAMENTO DE PROTEÇÃO } \\
\text { INDIVIDUAL) }\end{array}$ & $\begin{array}{l}\text { VESTIMENTA / ROUPA DE PROTEÇÃO / } \\
\text { CAPA GROSSA }\end{array}$ \\
\hline LANGSTROTH & $\begin{array}{l}\text { CAIXA ARTIFICIAL / CAIXA PADRÃO / } \\
\text { STANDARD / UNIVERSAL }\end{array}$ \\
\hline TELA EXCLUIDORA & APARTADOR DE ABELHAS/ SEPARADOR \\
\hline GLOSSA & LÍNGUA / SUGADOR / LAMBEDOR \\
\hline OPERÁRIAS & OBREIRAS / TRABALHADEIRAS \\
\hline PREDADOR & PRAGA / INIMIGO DA ABELHA \\
\hline CÂMERA DE CRIA & NINHO / INCUBATÓRIO \\
\hline APITOXINA & VENENO \\
\hline
\end{tabular}




\begin{tabular}{|l|l|}
\hline \multicolumn{2}{|c|}{ AVICULTURA } \\
\hline \multicolumn{1}{|c|}{ LÉXICO ESPECIALIZADO } & \multicolumn{1}{c|}{ LÉXICO COMUM } \\
\hline GALPAÕ AVIÁRIO / AVIÁRIO & POLEIRO / GALINHEIRO \\
\hline AVE DE POSTURA & GALINHA POEDEIRA / BOTADEIRA \\
\hline GALINHA D'ANGOLA & $\begin{array}{l}\text { CAPOTE / ANGOLISTA / TÔ FRACO / GUINÉ / } \\
\text { COCAR }\end{array}$ \\
\hline VESÍCULA BILIAR & FELI / FEL \\
\hline CAMPÂNULA & $\begin{array}{l}\text { AQUECEDOR / ESQUENTADOR / FONTE DE } \\
\text { CALOR }\end{array}$ \\
\hline ADITIVO & MISTURA / SUPLEMENTO \\
\hline QUEBRA-VENTO & LONA / CORTINA \\
\hline BIOFERTILIZANTE & ADUBO \\
\hline BIOGÁS & GÁS NATURAL \\
\hline CÍRCULO DE PROTEÇÃO & SEPARADOR / PROTETOR \\
\hline FÓRMULA DA RAÇÃO / CÁLCULO DIÁRIO & $\begin{array}{l}\text { CÁLCULO DA COMIDA / BASE DA COMIDA / } \\
\text { COMPLEMENTAÇÃO }\end{array}$ \\
\hline HÍBRIDO & $\begin{array}{l}\text { MISTURA DE RAÇA / CRUZAMENTO / RAÇA } \\
\text { CRUZADA }\end{array}$ \\
\hline FRANGO DE CORTE & FRANGO DE GRANJA \\
\hline PROFILAXIA & HIGIENIZAÇÃO / DESENFECÇÃO / LIMPEZA \\
\hline LANTERNIM & $\begin{array}{l}\text { VENTILAÇÂOO / JANELA / CUMIEIRA } \\
\text { CORREDOR DE AR }\end{array}$ \\
\hline PEDILÚVIO & $\begin{array}{l}\text { LIMPADOR DE CALÇADOS / BURACO DE } \\
\text { LIMPEZA }\end{array}$ \\
\hline ZONA DE CONFORTO & TEMPERATURA IDEAL \\
\hline SELEÇÃO & SEPARAÇÃO / ESCOLHA \\
\hline
\end{tabular}




\begin{tabular}{|c|c|}
\hline \multicolumn{2}{|c|}{ BOVINOCULTURA } \\
\hline LÉXICO ESPECIALIZADO & LÉXICO COMUM \\
\hline COLOSTRO & LEITE SUJO / LEITE IMPURO \\
\hline MANEJO & CUIDADOS / SERVIÇOS / TRATAMENTO \\
\hline GESTANTE & PRENHA / AMOJADA \\
\hline ESTERCO & $\begin{array}{l}\text { ADUBO ORGÂNICO / ESTRUME / ADUBO / } \\
\text { BOSTA DE VACA / ESTRUME / ADUBO }\end{array}$ \\
\hline PROTEIRO & PIQUETE / CURRAL \\
\hline INVERNADA & PASTO GRANDE / PASTO / QUINTA \\
\hline CONTENÇÃO / IMOBILIZAÇÃO & AMARRA DO ANIMAL / PIAR O ANIMAL \\
\hline CASTRAÇÃO & CAPAÇÃO \\
\hline VACA INFÉRTIL & VACA MANINA / FÊMEA REFIGO \\
\hline COLUNA VERTEBRAL & ESPINHAÇO \\
\hline URINA & MIJO \\
\hline GIBA & CUPIM \\
\hline CAUDA & RABO \\
\hline MIÍASE & BICHEIRA \\
\hline HELMINTO & VERMES / LOMBRIGAS \\
\hline ERVA DANINHA & PRAGA / MATO \\
\hline CRESCIMENTO CESPITOSO & TOUCEIRA / MOITA \\
\hline BRETE / TRONCO & CORREDOR DE MANEJO / EMBARCADOR \\
\hline MARRAFA & TOPETE \\
\hline DESMAME & APARTAMENTO / SEPARAÇÃO \\
\hline ARISCO & VALENTE / BRAVO \\
\hline ABATEDOURO & MATADOURO \\
\hline ECTOPARASITA & CARRAPATO / MOSCA / BICHOS \\
\hline INSUFLADOR / ORDENHADEIRA & TIRADOR DE LEITE / TETEIRA / CHUPETA \\
\hline FRONTE / FRONTAL & TESTA \\
\hline
\end{tabular}




\begin{tabular}{|l|l|}
\hline MORÃO & TRONCO \\
\hline GORDURA & BANHA / TOUCINHO \\
\hline PORTEIRA & CANCELA \\
\hline VITELO & NOVILHO / BOGÔ / BEZERRO / TERNEIRO \\
\hline PRIMÍPARA & PRIMEIRA CRIA / CRIA NOVA \\
\hline TETA & MAMA / PEITO \\
\hline CIO & VIÇO \\
\hline FLANCO & VAZIO / ILHA \\
\hline DESMAMADOR DE BEZERRO & BABIDE / TABA \\
\hline ISOLADOR DE CERCA ELÉTRICA & CASTANHA DE CAJU \\
\hline CHAXO & FACÃO \\
\hline
\end{tabular}




\begin{tabular}{|c|c|}
\hline \multicolumn{2}{|c|}{ HORTICULTURA } \\
\hline LÉXICO ESPECIALIZADO & LÉXICO COMUM \\
\hline CANAL & VALA / REGO / BURACO / VALETA \\
\hline GERMINAÇÃO / EMERGÊNCIA & NASCIMENTO / BROTAÇÃO \\
\hline POLICULTIVO & $\begin{array}{l}\text { ASSOCIAÇÃO / ROÇA MISTURADA / } \\
\text { CONSÓRCIO / PLANTIO JUNTO }\end{array}$ \\
\hline SULCO / CAMALHÃO & LINHA / LEIRA / FILEIRA \\
\hline ESTIOLAMENTO & $\begin{array}{l}\text { ESMORECIMENTO / CAIMENTO / } \\
\text { ESBRANQUEAMENTO DA FOLHA / MORTE }\end{array}$ \\
\hline ANOMALIA & $\begin{array}{l}\text { DEFEITO / ABERRAÇÃO / DOENÇA / } \\
\text { ATROFIAMENTO }\end{array}$ \\
\hline MATERIA ORGÂNICA & ESTRUME / ESTERCO \\
\hline LEIVA / LEIRA & $\begin{array}{l}\text { TERRA LAVADRA / MONTE DE TERRA / TERRA } \\
\text { AMONTOADA }\end{array}$ \\
\hline ANCINHO & RASTELO / CISCADOR \\
\hline FUNGICIDA /DEFENSIVO AGRICOLA & VENENO / MATA TUDO \\
\hline HORTALIÇAS & VERDURAS / PLANTAÇÃO DE FOLHAS \\
\hline APILOAMENTO / COMPACTAÇÃO & $\begin{array}{l}\text { BATIMENTO DA TERRA / SOCAMENTO DA } \\
\text { TERRA / ATERRAMENTO / NIVELAMENTO / } \\
\text { NIVELAÇÃO / ATERRO }\end{array}$ \\
\hline EROSÃO & CORROSÃO / VOÇOROCA / BURACO \\
\hline CAULE & TALO / GALHO \\
\hline FENÓTIPO & APARÊNCIA / COR DA FLOR / FORMA \\
\hline REGADOR & AMOLHADOR / REGADOR / BICO DE PATO \\
\hline CAMPO & $\begin{array}{l}\text { ROÇA / SÍTIO / CHÁCARRA / MATO / FAZENDA / } \\
\text { CHACRA }\end{array}$ \\
\hline ARGILA / GREDA & BARRO / BARRO DE LOUÇA \\
\hline AGROVILA & $\begin{array}{l}\text { ASSENTAMENTO / P. A. (PROJETO DE } \\
\text { ASSENTAMENTO) / POVOADO }\end{array}$ \\
\hline PEDÚNCULO & PENDÃO / PENDICELO / PANÍCULA \\
\hline
\end{tabular}




\begin{tabular}{|l|l|}
\hline DEBULHA & DEBUIA \\
\hline MATURAÇÃO & AMADURECIMENTO / FLORAÇÃO \\
\hline TRATOR & JIRICO / MÁQUINA \\
\hline SOLO & TERRA / CHÃO / TERRENO \\
\hline GEMA & BROTO / OLHOS / ENFURQUIANDO \\
\hline PATOGÊNOS & DOENÇAS / PRAGAS \\
\hline FORRAGEM & CAMA / ADUBO \\
\hline ERVAS DANINHA & MATO / PRAGA \\
\hline GLEBA & PEDAÇO DE TERRA / LOTE \\
\hline
\end{tabular}




\begin{tabular}{|c|c|}
\hline \multicolumn{2}{|c|}{ SUINOCULTURA } \\
\hline LÉXICO ESPECIALIZADO & LÉXICO COMUM \\
\hline MARRÃ & LEITOA VIRGEM / PORCA VIRGEM \\
\hline CACHAÇO & BARRÃO / VARRÃO \\
\hline $\mathrm{ClO}$ & VIÇO \\
\hline CASTRAÇÃO & CAPAÇÃO / AMPUTAÇÃO \\
\hline RECEITA & LUCRO \\
\hline ODOR & $\begin{array}{l}\text { FEDOR / CATINGA / FEDOR DE BARRÃO / } \\
\text { ODOR / }\end{array}$ \\
\hline BAIA & BOXE / CHIQUEIRO \\
\hline CONSTIPAÇÃO & $\begin{array}{l}\text { OBSTIPAÇÃO / PRISÃO DE VENTRE / } \\
\text { EMPAZINAÇÃO }\end{array}$ \\
\hline CORREDOR DE MANEJO & BRETE \\
\hline ESCAMOTEADOR & ABRIGO PARA RECÉM-NASCIDO \\
\hline LANTERNIM & CUMIEIRA / VENTILAÇÃO / ABERTURA \\
\hline ONFALITE & INCHAÇO NO UMBIGO \\
\hline PERDAS EMBRIONÁRIAS & ABORTO / PERDA \\
\hline GESTANTE & PRENHA / AMOJADA / INCHERTADA \\
\hline MONTA & $\begin{array}{l}\text { ACASALAMENTO / CRUZAMENTO / } \\
\text { COBERTURA }\end{array}$ \\
\hline TETAS & MAMAS / PEITOS \\
\hline FLANCO & VAZIO / ILHA \\
\hline INSTALAÇÕES & GALPÃO SUÍNO / GRANJA \\
\hline GORDURA & BANHA / TOUCINHO \\
\hline MIÍASE & BICHEIRA \\
\hline LOMBO & COSTAS / SUAM \\
\hline ESCROTO & SACO / TESTÍCULOS \\
\hline CALHA & BIQUEIRA / BEIRAL \\
\hline POCILGA & CHIQUEIRO / BAIA \\
\hline
\end{tabular}


